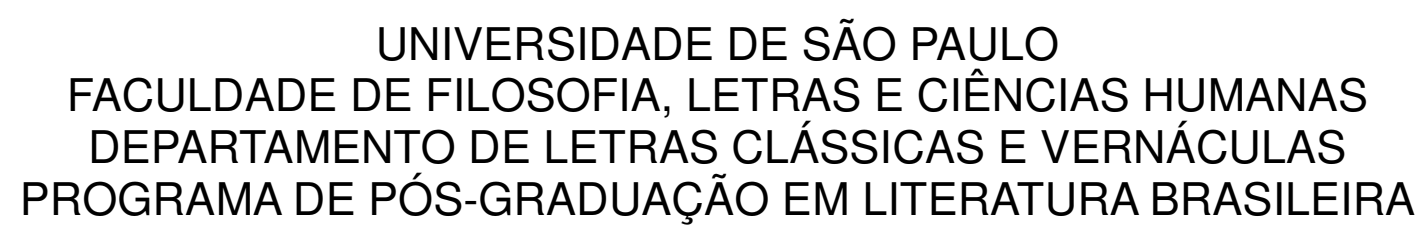

Gabriela Viacava de Moraes

QUE DIABO DE GÊNIO O DESSA RAPARIGA?

A construção do feminino em Lucíola, de José de Alencar.

São Paulo

2012 


\author{
UNIVERSIDADE DE SÃO PAULO \\ FACULDADE DE FILOSOFIA, LETRAS E CIÊNCIAS HUMANAS \\ DEPARTAMENTO DE LETRAS CLÁSSICAS E VERNÁCULAS \\ PROGRAMA DE PÓS-GRADUAÇÃO EM LITERATURA BRASILEIRA
}

Gabriela Viacava de Moraes

\title{
QUE DIABO O GÊNIO DESSA RAPARIGA? \\ A construção do feminino no romance Lucíola, de José de Alencar
}

Dissertação apresentada ao Programa de Pós-

Graduação em Literatura Brasileira do

Departamento de Letras Clássicas e Vernáculas da Faculdade de Filosofia, Letras e Ciências Humanas da Universidade de São Paulo, como exigência parcial para a obtenção do título de Mestre em Letras.

Orientador: Profa. Dra. Cilaine Alves Cunha.

Versão corrigida o exemplar original se encontra disponível no $\mathrm{CAPH}$ da FFLCH

São Paulo

2012 
Para Olimpia Viacava e

Rubens de Moraes (em memória) 


\section{AGRADECIMENTOS:}

Agradeço especialmente à Cilaine pela orientação afetuosa e enriquecedora.

Aos professores Eduardo Vieira Martins e Valéria de Marco pelos comentários iluminadores e pelas sugestões generosas durante o exame de qualificação.

Às companheiras do grupo de estudos de gênero da Acepusp, onde o embrião desta pesquisa surgiu: Julia, Cris, Talita, Tatiana, Camila, Cecília, e tantas outras que por lá passaram deixando suas reflexões.

Aos meus pais pelo apoio e pelo esforço constante em compreender as minhas escolhas.

Ao querido tio Francisco pelo suporte imensurável, pela acolhida carinhosa no Rio de Janeiro e por ter sido sempre uma grande referência.

Aos amigos, em especial, à Andréia Menezes que me guiou pelos caminhos tortuosos da burocracia acadêmica, à Bárbara Araújo pelas conversas literárias e femininas e ao Ferenc pela ajuda na diagramação.

A todos os que, direta ou indiretamente, contribuíram com sugestões ao trabalho: amigos, professores e familiares.

Ao Rodrigo pelo companheirismo e pela paciência.

À Capes pelo subsídio. 


\section{RESUMO}

O trabalho propõe, a partir do romance Lucíola, uma análise da imagem da mulher construída por José de Alencar, do arsenal simbólico utilizado nesta construção e da maneira como a representação do feminino neste romance reflete a moral da época. O objetivo é abordar o antagonismo presente na obra buscando mostrar como ele se faz presente não apenas na estrutura da narrativa, como na própria heroína: ser bifronte, ao mesmo tempo virgem e bacante. Além disso, procuraremos analisar em que medida a construção da personagem reflete uma ambição mimética e documentadora, ainda que indireta, do presente histórico. Mostraremos que o paradigma de feminilidade construído por Alencar nesta obra reflete a busca por certo progressismo sem, no entanto, colocar em cheque os valores básicos da moral e da família, acompanhando o ritmo de nossa modernização conservadora.

Palavras-chave: José de Alencar, Lucíola, romantismo, feminino, mulher. 


\begin{abstract}
The aim of this study is to analyze the representation of woman in the novel Lucíola, by José de Alencar, paying attention on its symbolic elements and verifying how the image of women built by Alencar in this work reflects the moral of its time. The main idea is to focus on the antagonism presented in the novel searching how it is part not only of the narrative structure but also of the constructed hero: a duplicated being, at the same time a virgin and a mistress. Besides that, the study intends to analyze to what extend the building of the character reflects a mimetic or a documentary ambition, even if indirect, of the historical moment. In the end, we will show that the paradigm of femininity built by Alencar in this work reflects the search of some sort of progressivism, although it doesn't call into question the basic values of moral and family, keeping pace with our conservative modernization.
\end{abstract}

Keywords: José de Alencar, Lucíola, romanticism, female characters, women. . 


\section{SUMÁRIO}

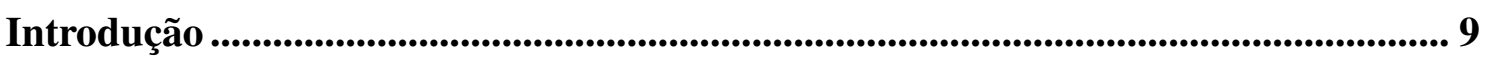

1 Entre Preces e Prescrições. ........................................................................... 13

1.1 O século XIX no Rio de Janeiro.................................................................. 14

1.2 A mulher de elite na sociedade fluminense oitocentista............................... 17

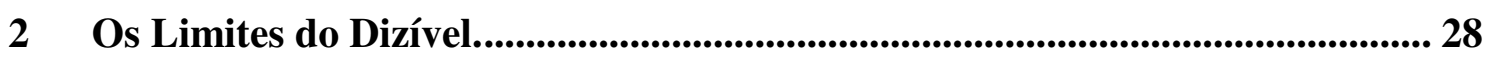

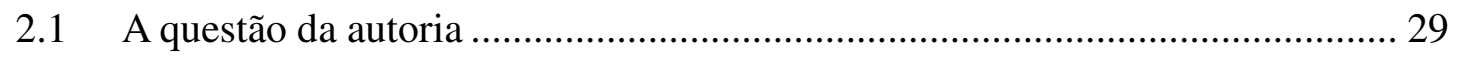

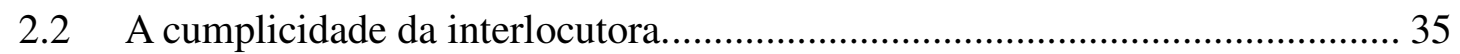

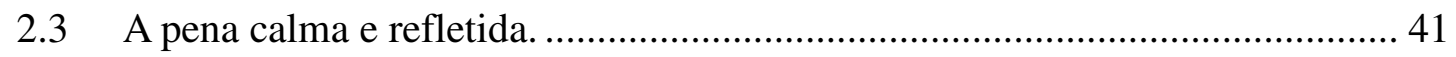

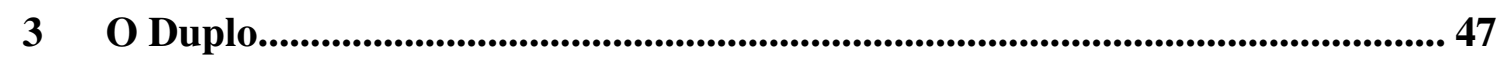

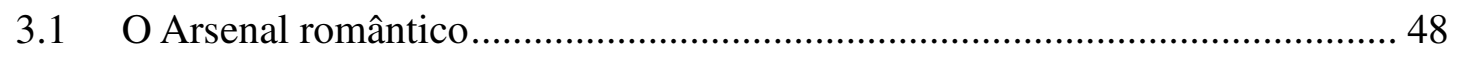

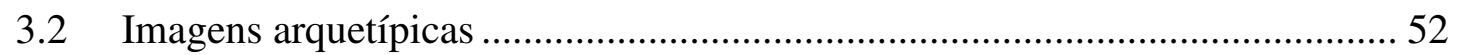

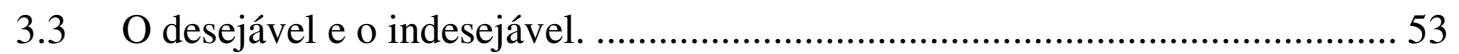

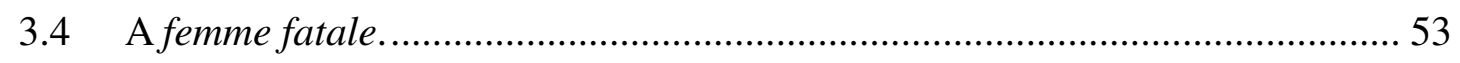

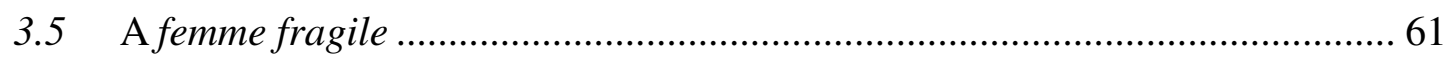

4 Que Diabo de Gênio o dessa Rapariga? .................................................................. 69

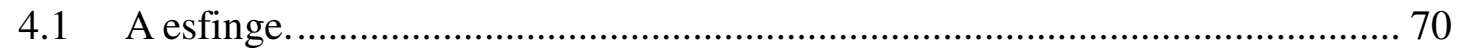

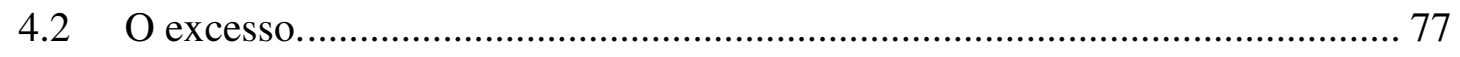

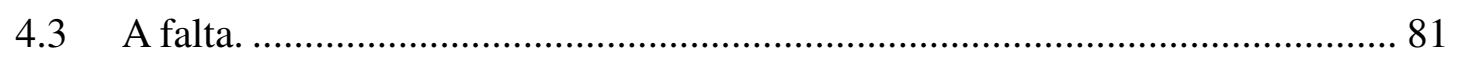

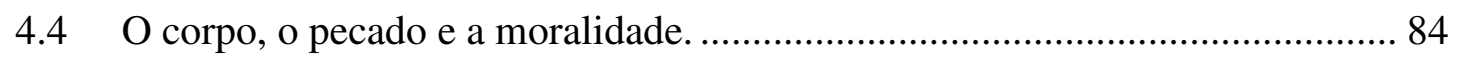

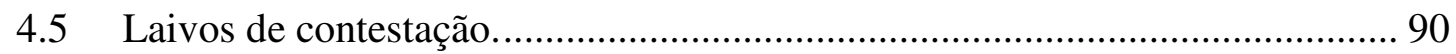

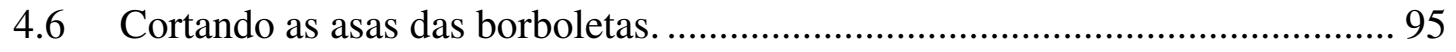

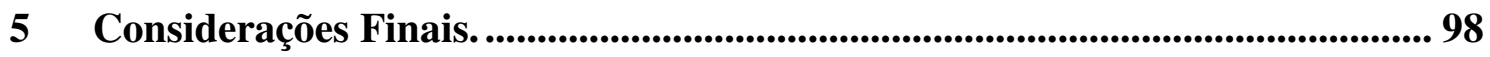

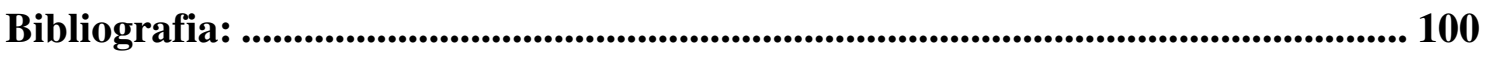


"Amiúde, as jovens belezas destinadas a um futuro glorioso começam aparecendo num papel de vítima; as histórias de Geneviève de Brabant, de Grisélidis, não são tão inocentes quanto parecem; amor e sofrimento nelas se entrelaçam de maneira perturbadora; é caindo no fundo da abjeção que a mulher assegura para si mesma os mais deliciosos trunfos; quer se trate de Deus ou de um homem, a menina aprende que acitando as mais profundas demissões, ela se tornará todo-poderosa; ela se compraz com um masoquismo que lhe promete supremas conquistas. Santa Blandina, branca e ensaguentada nas garras dos leões, Branca de Neve jazendo como morta num esquife de vidro, a Bela Adormecida, Átala desfalecida, toda uma corte de ternas heroínas machucadas, passivas, feridas, ajoelhadas, humilhadas, ensinam à jovem irmã o fascinante castigo da beleza martirizada, abandonada, resignada."

(Simone de Beauvoir)

"Do rio que tudo arrasta se diz que é violento Mas ninguém diz violentas as margens que o comprimem”.

(Bertolt Brecht) 
"Creio que aqueles que dão ao cólera o gênero feminino têm alguma razão, por isso que os maiores flagelos deste mundo, a guerra, a morte, a fome, a peste, a miséria, a doença, etc., são representados por mulheres. E o que torna-se mais notável ainda é que os gregos, gente sempre tida em conta de sábia, quando inventaram os seus deuses fizeram homens Apolo e Cupido, e para as mulheres escolheram as Purcas, as Fúrias e as Harpias.

Se as minhas amáveis leitoras não gostaram desta razão, que acho muito natural, chamem as contas os pintores e poetas, que são os autores de tudo isto. Quanto a mim, não tenho culpa nenhuma das extravagâncias dos outros, e até estou pronto a admitir a opinião do meu colega A. Karr, que explica aquele fato pela razão de que as senhoras são extremas em tudo, tanto que as mais belas coisas deste mundo são também significadas por mulheres, assim como a beleza, a glória, a justiça, a caridade, a virtude e muitas outras que, como estas, não se encontram comumente pelo mundo, mas que existem no dicionário." 


\section{INTRODUÇÃO}

Simone de Beauvoir, em O Segundo Sexo, explica que, desde as sociedades mais primitivas, a mulher sempre esteve na posição do outro. Segundo a autora, há um tipo humano absoluto, masculino. A mulher, por possuir ovários e um útero reuniria em si, as condições singulares que a encerram em sua subjetividade. A alteridade, no entanto, considerada por Beauvoir como categoria fundamental do pensamento ("nenhuma coletividade se define como Uma sem colocar diretamente a Outra diante de si"), é tradicionalmente percebida como uma falha, um desvio e, portanto, como o Mal: "é a diversidade que quebra a unidade, a matéria oposta à forma, a desordem que resiste à ordem"1. Posto que a história, assim como a literatura e as artes em geral, foram, até meados do século passado, produzidas quase exclusivamente por homens, é natural que, nelas também, a mulher tenha sido condenada a desempenhar o papel desse outro, que bem longe de ser "descrito" ou "contado", é antes, imaginado ou representado. Evidentemente, as imagens produzidas por homens dizem muito mais sobre aqueles que as produziram do que sobre as mulheres reais.

Assim, é necessário deixar claro, antes de mais nada, que o trabalho aqui apresentado, ao propor uma análise da representação da mulher no romance Lucíola, de José de Alencar, não pretende oferecer um estudo sobre a vida das mulheres da época. Realiza-se, antes, como uma tentativa de compreender a imagem da mulher construída pelo autor, o arsenal simbólico utilizado nessa construção, e a maneira como a representação do feminino em Alencar reflete a moral de sua época e da escola literária em vigor. Espera-se, desse modo, dar uma contribuição à crítica sobre o autor.

A opção por trabalhar com a personagem Lúcia, dentre tantas outras criaturas engenhosas construídas por Alencar, se deu por diversos motivos. Em primeiro lugar, em Lucíola, mais do que em qualquer outro romance do autor, a narrativa incorpora uma infinidade de imagens arquetípicas relacionadas a dois espaços antagônicos: o mundo "real”, espaço da degradação dos valores, materializado na heroína cortesã entre imagens violentas e animalescas; e o mundo ideal, utópico, tocado pelo amor romântico,

1 BEAUVOIR, Simone. O Segundo Sexo, v.1. Paulo: Nova Fronteira, 1980, p. 11 e 12. 
protagonizado pela menina-moça, angelical e abnegada. Tal dicotomia, sem dúvida coerente com os pressupostos do romantismo brasileiro, permite, pela clareza dos extremos, uma visão mais direta do senso de propósito moral e do zelo didático utilizado por Alencar no intuito de construir um paradigma de feminilidade que, por meio da antítese vício-virtude, pudesse reproduzir os ditames da moralidade burguesa.

Em segundo lugar, porque para além do bifrontismo aparentemente simples e arquetípico que caracteriza a personagem em questão, é possível perceber um comportamento contraditório, que oscila entre os extremos da avidez sexual e da frigidez, do desejo e do recalque, e que aponta para a existência de uma dimensão humana surpreendente, talvez só comparável, dentro da produção ficcional romântica brasileira, a outra heroína dos "perfis": Aurélia. Tal dimensão humana reflete uma modernidade que só pôde ser compreendida pela crítica quase um século depois que a narrativa foi escrita e que pode ser entendida como um prelúdio daquilo que viria a se chamar "romance psicológico".

É assim que, ao pensar a representação da mulher nesta obra de Alencar, fui levada a outra importante questão: a oscilação entre a imitação da realidade e o exercício da fantasia, ponto nevrálgico dos romances alencarianos. De modo geral, parece possível afirmar que, enquanto os romances históricos e indianistas de Alencar pendem mais para o fantasioso, por influência de Walter Scott e Chateaubriand; a ficção urbana parece pender apara o realismo, à maneira de Balzac, Feuillet e Sand. No entanto, de uma forma ou de outra, Alencar foi acima de tudo um escritor imaginativo, e toda a sua obra, presa aos cânones do romantismo vigente, demonstra uma forte tendência ao metafórico, muito mais do que ao imitativo. Caberá, portanto, também, pensar em que medida Lúcia foi construída através dos padrões arquetípicos das correntes românticas em voga no Brasil, e, em que medida a construção da personagem reflete uma ambição mimética, fisiológica (na confluência dos "estudos de temperamento", de Balzac) e documentadora, ainda que indireta, do presente histórico.

Tendo em vista que as representações literárias são encarnações da cultura que as gera e que, portanto, a obra de um escritor está intimamente ligada ao contexto social em que é produzida, o primeiro capítulo deste trabalho se propõe a apresentar um 
esboço da condição social da mulher de posses no Rio de Janeiro oitocentista. Mais uma vez, é necessário esclarecer que o texto, longe de se apresentar enquanto um estudo aprofundado sobre a situação a família brasileira no século XIX fluminense, procura apenas situar historicamente a análise que será feita nos capítulos seguintes. A perspectiva adotada neste breve apanhado de informações sobre a mulher é burguesa, já que a ótica que Alencar adota, nesse como nos demais romances urbanos, é a da família burguesa citadina, especialmente direcionada para as questões relacionadas ao amor e ao casamento.

No segundo capítulo, o trabalho se volta especificamente para a obra escolhida. No entanto, antes de me aprofundar na análise da construção da protagonista - e tendo em vista que ela não pode ser compreendida isoladamente - procurarei abordar outros elementos estruturais da obra, como a questão do pseudônimo utilizado pelo autor, e a preocupação de Alencar com a maneira de narrar, que se reflete no policiamento da linguagem e no desdobramento do narrador. Neste capítulo, a ênfase cairá, em especial, em outra personagem feminina de bastante relevância para a temática abordada: G.M., a interlocutora cúmplice do autor que, ao conduzir e orientar a interpretação do público leitor, apresenta-se também como um importante recurso didático que reafirma o propósito pedagógico inerente à obra de Alencar.

O terceiro capítulo deste trabalho marca o momento em que análise se volta especificamente para a protagonista. Nele, procurarei abordar o antagonismo entre o bem e o mal presente na obra, buscando mostrar como o substrato mítico ligado aos mundos apocalíptico e demoníaco, deslocado para a experiência humana, se faz notar não apenas na estrutura da narrativa, como na própria construção da heroína: ser bifronte, ao mesmo tempo virgem e bacante. Para tanto, utilizarei, sobretudo, a "Teoria dos Arquétipos" desenvolvida por Northrop Frye em Anatomia da Crítica.

No quarto capítulo, o trabalho procura abordar com mais profundidade o comportamento oscilatório de Lúcia à luz da crítica recente (especialmente Antonio Candido e Dante Moreira Leite) para compreender de que maneira a construção desta protagonista de Alencar aponta para uma ruptura com o psicologismo tipificado próprio das personagens da narrativa romanesca, anunciando uma adesão ao romantismo de 
tendência realista. Neste capítulo, procurarei apontar, também, os aspectos da narrativa que demonstram o diálogo de Alencar com os discursos médico e religioso em voga no Rio de Janeiro oitocentista.

Por fim, o trabalho procura demonstrar que nesta obra, como em maior ou menor grau no resto de sua ficção urbana, Alencar constrói uma imagem de mulher que introjeta e ajuda a reforçar os padrões morais da sociedade em que está inserido. Não obstante, o autor esforça-se para, ao mesmo tempo, imprimir às heroínas, em especial às dos "perfis", um elevado grau de sagacidade, prepotência e despeito que contrasta com a fragilidade de seus pares masculinos. Lúcia (assim como Aurélia e Emília) é uma mulher com voz própria capaz de se colocar contra a sociedade que a cerca e analisar criticamente a condição em que se encontra. Isso tudo não impede, no entanto, que, ao final da obra, acabe se ajustando no ideal feminino do narrador e, portanto, do autor. Nesse sentido, o paradigma de feminilidade construído por Alencar neste, como nos demais "perfis", reflete a busca por certo progressismo, sem, no entanto, colocar em cheque os valores básicos da moral e a família, acompanhando o ritmo de nossa modernização conservadora. 


\section{Entre Preces e Prescrições.}

Essa obrigação de casar as mulheres é o diabo! ... Se não tomam estado, ficam jururus e fanadinhas...; se casam podem cair na mão de algum marido malvado... E depois, as histórias!... Ih, meu deus, mulheres numa casa é coisa de meter medo ... São redomas de vidro que tudo pode quebrar... Cruz! Botam a família inteira a perder, enquanto o demo esfrega um olho.

(Visconde de Taunay, Inocência) 


\subsection{O século XIX no Rio de Janeiro}

O século XIX no Brasil foi marcado por uma série de transformações políticas, culturais e econômicas que reorganizaram as vivências familiares e domésticas e redefiniram, entre outras questões, o papel da mulher na sociedade. A chegada da família real portuguesa, em 1808, e a abertura dos portos foram responsáveis por um aumento de quase um terço da população urbana no Rio de Janeiro e pelo início de um processo de modernização que se intensificou cada vez mais até meados do século XX. Embora o trabalho escravo e o latifúndio - os dois grandes pilares do sistema de produção colonial - permanecessem inalterados, o país foi, ao longo do século, se adaptando, de maneira canhestra, ao ritmo econômico imposto pelo capitalismo que iria, enfim, gradativamente, se consolidar em solo nacional.

O Rio de Janeiro no início do século XIX era uma cidade simples, desorganizada, incapaz de proporcionar o conforto e a sofisticação com os quais a Corte portuguesa estava habituada. Diante da urgência de se adequar à nova situação, a sociedade fluminense foi obrigada a amenizar suas deficiências urbanas. Assim, já nas primeiras décadas, a cidade passou a assumir gradativamente um aspecto menos caótico: as ruas receberam calçamento, os lampiões de azeite cresceram em número e foram posteriormente substituídos pela iluminação a gás, a limpeza pública passou a funcionar permitindo que as ruas deixassem de ser usadas como local de escoamento de fezes e outros detritos. Ao mesmo tempo, a Missão artística francesa, que desembarcou no Brasil em 1816, foi responsável pela consolidação da, ainda tímida, vida intelectual da cidade com a criação da Biblioteca Nacional, da Academia Real de Desenho, Pintura e Escultura, do Observatório Astronômico, da Imprensa Régia, do Real Teatro São João. Mais tarde, com a Independência, a necessidade de formação de uma elite econômica brasileira proporcionou ainda a fundação de algumas faculdades como as do Rio de Janeiro, Recife e São Paulo. ${ }^{2}$

O processo de transformação política e econômica motivado pela chegada da

2 As informações aqui presentes foram retiradas, principalmente, de COSTA, Jurandir Freire, Ordem Médica e Norma Familiar, São Paulo: Graal, 2004 ; FREYRE, Gilberto, Sobrados e Mucambos, São Paulo: Global Editora, 2003 e COSTA, Emília Viotti da, Da Monarquia à República, São Paulo: Editora Unesp, 1998. 
Corte atingiu também a estrutura social e familiar da sociedade fluminense. Para as famílias de posses, a condição para legitimar seu prestigio foi se "europeizar", isto é, definir-se como classe em ascensão por meio da adoção de hábitos e valores do liberalismo europeu. A nova moral burguesa, no entanto, ao se estabelecer no Brasil, entrou em confronto com os antigos hábitos, próprios de uma sociedade cuja estrutura, como mencionado, ainda se encontrava assentada sob domínio do grande proprietário rural. O embate entre tais forças marcou o ritmo da nossa "modernização conservadora". Assim, a sociedade fluminense, diante da urgência de nivelar-se à burguesia e à aristocracia europeias, teve que, sistematicamente, lutar contra comportamentos, atitudes e hábitos tradicionais que eram considerados inadequados à nova situação. Dentre estes hábitos, segundo Jurandir Freire, havia uma questão que principalmente preocupava a Metrópole: a ineficácia da política colonial de controle social que, funcionando com base em práticas essencialmente punitivas, como os açoites, exílios e enforcamentos, mostrava-se cada vez mais incapaz de coibir a indisciplina urbana e os sempre eminentes levantes populares. A estratégia de recrutamento de civis, utilizada até então, mostrava-se também problemática na medida em que, ao militarizar parte da população, aumentava os riscos de uma insurreição armada. $^{3}$

Respaldada na suposta necessidade de conter o caos urbano e proteger os interesses da Nação, a sociedade fluminense passava a se inserir no processo que Michel Foucault aponta como uma tendência do Estado Moderno: a evolução gradativa de uma estratégia de controle social baseada em uma postura repressiva, estruturada em um poder coercitivo, para uma postura preventiva que visava, ao invés, normatizar o comportamento social com base em dispositivos formados por práticas discursivas, tais como: concepções filosóficas, princípios religiosos e enunciados científicos ${ }^{4}$. A política da medicina higienista, inserida no Rio de Janeiro oitocentista pela chave da salubridade, do controle de febres, pragas, epidemias e infecções, foi a vertente mais claramente valorizada deste processo.

3 C.f. COSTA, Jurandir Freire. Ordem Médica e Norma Familiar, op. cit.

4 C.f. FOUCAULT, Michel. A História da Sexualidade - a vontade de saber. Vol.1. São Paulo: Graal, 2007. 
Incitando cada indivíduo a preocupar-se com a própria saúde, e dirigido especialmente às famílias de elite, o discurso higiênico buscava modificar os hábitos e valores da tradição colonial que passavam a ser considerados nocivos, ao mesmo tempo em que estabelecia um novo código de relações afetivas que passava a censurar e regular o comportamento dos habitantes da cidade nas mais diversas circunstâncias da vida privada e social. Nesse sentido, a consequência mais notável da ingerência da medicina higienista na vida privada foi a alteração gradativa da estrutura patriarcal de organização familiar para o modelo atual nuclear e conjugal. A família proprietária rural, antes isolada, e com o poder garantido pela posse de terras e escravos, foi obrigada a se adaptar à urbanização e à nova moral passando por um processo de aburguesamento. Muitas famílias passaram a adquirir imóveis na cidade e o confinamento deixava de ser uma marca de distinção à medida que um novo espaço de sociabilidade surgia: bailes, saraus, festas privadas e o teatro passaram a ser valorizados pelas classes altas como ambientes propícios para selar interesses políticos e econômicos, dentre os quais incluía-se o casamento.

Paralelamente ao movimento de exteriorização da família, iniciava-se ainda, no decorrer do século XIX, no Rio de Janeiro, um processo de privatização da vida familiar. A família colonial estendida, que incorporava parentes agregados, vizinhos e escravos à esfera doméstica, passava a ser considerada anti-higiênica. A propaganda abolicionista se disseminava e, pouco a pouco, os escravos iam sendo excluídos do ambiente interno da casa. À medida que a família se fechava, reduzindo-se cada vez mais à esfera nuclear composta apenas por pais e filhos, começava a ocorrer também o que se pode chamar de individualização de seus membros. O sujeito individual, recentemente isolado no velho mundo pela revolução burguesa, buscava, contraditoriamente, se consolidar no Brasil escravista. A higiene, reforçando no imaginário oitocentista a convicção de que cada indivíduo, isoladamente, devia efetivamente participar do governo da Nação, fazia com que os membros da família passassem da tutela do pai para a tutela do Estado. A experiência emocional e pessoal dos filhos passava, assim, a ser cada vez mais valorizada, ao mesmo tempo em que a 
autoridade do pater famílias se dissolvia ${ }^{5}$.

\subsection{A mulher de elite na sociedade fluminense oitocentista}

"Há um princípio bom que criou a ordem, a luz, o homem; e um princípio mal que criou o caos, as trevas, a mulher"

Pitágoras

Em uma formação social escravista como a que se deu no Brasil desde o século XVI, não havia espaço para a constituição de um sistema de educacional formal. Até a transferência da Corte, a formação ideológica e profissional da classe dominante brasileira era centralizada na metrópole, e a educação dos escravos era considerada tão desnecessária quanto perigosa aos interesses da empresa colonial. Assim, a ignorância e o obscurantismo na colônia eram levados ao extremo, e a Igreja - por meio da catequese, do calendário religioso, da confissão, dos sermões dominicais, enfim, de uma ampla vigilância doutrinal e de costumes - constituía-se como o principal aparelho ideológico no país até meados do século XIX.

No plano científico, a situação não era diferente. A historiadora Mary Del Priore, em ensaio sobre a medicina na colônia, demonstra como os médicos no Brasil, tanto nos povoados quanto nos centros mais populosos, tinham uma formação precária e estavam alheios às descobertas da medicina recente. Segundo Priore, a colônia acompanhava os passos da metrópole, onde, durante os séculos XVI e XVII, o Tribunal do Santo Ofício, a Companhia de Jesus e o pensamento contra reformista ofereciam os mais rígidos obstáculos a qualquer tipo de avanço científico e cultural. Como consequência desta política, o curandeirismo se espalhava, tanto em Portugal quanto no Brasil, ocupando naturalmente a lacuna deixada pela medicina formal. Dentro deste cenário, ainda segundo Priore, as doenças, eram interpretadas como advertências divinas, punições legítimas pelos desvios morais cometidos:

5 C.f. MURICY, Katia. A Razão Cética, Machado de Assis e as Questões de seu tempo. São Paulo: Cia das Letras, 1988. 
Considerado um pai irado e terrível, Deus afligiria os corpos com mazelas na expectativa de que seus filhos se redimissem dos pecados cometidos, salvando, assim, suas almas. A enfermidade era vista por muitos pregadores e padres, e também por médicos da época, como um remédio salutar para os desregramentos do espírito. Nessa perspectiva, a doença nada mais era do que o justo castigo por infrações e infidelidade perpetradas pelos seres humanos ${ }^{6}$.

Em meio a esse tipo de mentalidade que associava o mal estar físico à culpa e ao pecado, a mulher era considerada naturalmente disposta à transgressão, à desordem, ao demônio. A menor enfermidade, qualquer crise, qualquer tipo de comportamento tido como incomum para os padrões da época, quando diagnosticados na mulher, eram considerados sinais de possessão demoníaca, ou manifestações de uma força divina que buscava expurgar a essência diabólica supostamente presente em cada mulher. $\mathrm{O}$ corpo feminino, fértil, e por isso assimilado, desde as primeiras comunidades agrícolas, à natureza e seus mistérios, era visto como um elemento estranho, imprevisível, que encarnava o perigoso estigma da perturbação social. A ignorância anatômica, a falta de conhecimentos fisiológicos, as fantasias relacionadas à anatomia feminina, faziam com que cada elemento de seu organismo despertasse desconfiança. O sangue menstrual, por exemplo, era considerado um veneno poderoso capaz de provocar a loucura e a morte; o útero era tido como um animal oculto no interior do organismo que, quando contrariado, tornava-se responsável pela ninfomania e pelo "mal histérico", . Ainda nas palavras de Priore:

Como a mulher era considerada por natureza uma agente de Satã, toda a sua sexualidade podia prestar-se à feitiçaria, como seu corpo, ungido pelo mal, correspondesse às intenções malignas de seu senhor. Cada pequena parte seria representativa desse conjunto diabólico, noturno e obscuro. ${ }^{8}$

Esta mística nebulosa em torno do corpo feminino presente no imaginário

6 DEL PRIORE, Mary. "Magia e Medicina na Colônia". In: .DEL PRIORE, Mary (org.) História das Mulheres no Brasil, op. cit, p. 80. Da mesma autora, veja-se também: Ao Sul do Corpo: condição feminina, maternidade e mentalidades do Brasil Colônia. Rio de Janeiro: José Olimpio: Brasília, D.F: Edunb, 1993.

7 C.f . DEL PRIORE, Mary . In: DEL PRIORE, Mary (org). História das Mulheres do Brasil, op. cit.

8 Idem, p. 112. 
colonial transformava a mulher em alvo de uma intensa política repressiva. A Igreja e o Estado exerciam uma forte pressão sobre a sexualidade feminina, abafando-a, no intuito de preservar "o equilíbrio doméstico, a segurança do grupo social e a própria ordem das instituições civis eclesiásticas" "s supostamente ameaçados pelo furor uterino. Assim, as mulheres de posses eram colocadas sob forte vigilância de pais, irmãos, tios, tutores, interessados em preservar a honra e os bens da família. A escassa educação que recebiam dirigia-se exclusivamente para os afazeres domésticos, e o analfabetismo era encarado como sinal de distinção e nobreza.

Para evitar relações indesejadas que pudessem comprometer o patrimônio, o confinamento feminino - antigo costume português de origem árabe - era também muito comum nas famílias brasileiras ricas até, pelo menos, as primeiras décadas do século XIX. Isoladas nos fundos das casas, ou dentro das alcovas úmidas e escuras, escondidas por trás de rótulas e gelosias, as mulheres de posses quase não eram vistas, tanto na rua, quanto dentro de casa na presença de visitas. Ao chegar ao Brasil em 1808, o mercador britânico John Luccock emitiu o seguinte relato em relação às mulheres do Rio de Janeiro:

Raramente se viam fora de casa, salvo para irem à missa, muito cedo, pelas quatro da manhã, nos dias santos ou dias de obrigatoriedade devocional; mas, mesmo então, o vulto todo e mais o rosto iam de tal forma envolvidos em mantos, ou ocultos través de cortinas de uma cadeira, que impediam de gozar do ar fresco, escondendo todas as feições, com única exceção talvez de olhos tagarelas e maus. ${ }^{10}$

É bem verdade, no entanto, que apesar da maioria das mulheres de elite da época terem se sujeitado passivamente a essas determinações, não foram poucas as que ousaram enfrentar as instituições e a sociedade de seu tempo. Dentre os relatos de estrangeiros em visita ao Brasil, desde o início da colonização, tanto na Corte quanto nas demais regiões do país, há inúmeros exemplos de mulheres rebeldes que encontraram meios de escapar à vigilância de pais e maridos, arriscando-se em fugas e

9 ARAÚJO, Emmanuel. "A Sexualidade na Colônia". In: DEL PRIORE, Mary (org.). História das Mulheres no Brasil, op. cit, p.45.

10 LUCCOCK, John. Notas sobre o Rio de Janeiro e partes meridionais do Brasil. Tomadas durante uma estada de dez anos nesse país, de 1808 a 1818. São Paulo: Martins, 1942, p. $75-80$. 
adultérios ou reivindicando o divórcio. Esse comportamento, no entanto, apesar de comum, não parece ter sido hegemônico, já que os mecanismos de cerceamento por parte da Igreja e do Estado eram bastante eficientes e, de um modo geral, as próprias mulheres introjetavam os valores misóginos predominantes no meio social ${ }^{11}$.

De uma forma ou de outra, com a chegada da Corte, a rotina feminina nas famílias citadinas passou a ser bastante alterada. A ordem burguesa emergente pôs fim ao regime de clausura incentivando a mulher a se expor na nova vitrine social. Assim, gradativamente, ao longo do século, a mulher de elite ganhava a rua, frequentando bailes, salões, saraus, o teatro. O casamento entre famílias da elite transformava-se em um degrau de ascensão social ou uma forma de manutenção do status. As mulheres solteiras deveriam esforçar-se para obter um casamento lucrativo. As casadas assumiam novas funções: exigia-se que elas soubessem receber as visitas dos maridos, que os incentivassem na vida pública, que supervisionassem a vida doméstica de modo a manter o elevado nível de prestígio da família. De maneira geral, segundo Gilberto Freyre, as transformações sociais do Rio de Janeiro do século XIX promoveram uma "alargamento da paisagem social" da mulher de elite "no sentido de uma variedade maior de contatos com a vida extradoméstica" por meio "do teatro, do romance, da janela, do estudo de dança, de música, de francês"12

Publicado em 1872, o romance Inocência de Visconde de Taunay, oferece um detalhado retrato da vigilância e do despotismo paternal no interior do Mato Grosso em meados de 1860, demonstrando que, fora da Corte, as mudanças foram mais lentas e os hábitos permaneceram inalterados até, pelo menos, a segunda metade do século. Pereira, o sertanejo de padrões morais rígidos, que mantinha a filha em rigorosa clausura para evitar o contato masculino, justifica-se por meio de um discurso que condena as supostas "modernidades" dos costumes das cidades:

Contaram-me que nas cidades ... arrenego!... não há menina, por mais pobrezinha que seja, que não saiba ler livros de letra de forma e garatujar no papel... que deixe de ir a fonçonatas e com vestidos

11 C.f. ALMEIDA, Suely Cordeiro. O Sexo Devoto: normatização e resistência feminina no Império Português XVI - XVIII. Ed. Universitária da UFPE, 2005.

12 FREYRE, Gilberto. Sobrados e Mucambos, op. cit, p. 228. 
abertos na frente como raparigas fadistas e que saracoteiam em danças e falam alto e mostram os dentes por dá cá aquela palha com qualquer tafulão...Cruz! ... Assim também é demais; não acha? Cá no meu modo de pensar, entendo que não se maltratem as coitadinhas; mas também não é preciso dar asas a formigas... Quando elas ficam taludas; atamanca-se uma festa para casá-las com um rapaz decente ou algum primo e acabou-se a história...

Ainda sem acesso à educação formal e com uma possibilidade maior de contato, mesmo que superficial, com as artes e a literatura, a mulher burguesa do Rio de Janeiro elegia a leitura de romances como uma ocupação privilegiada. Eram narrativas romanescas lidas comumente em voz alta para um auditório feminino, ou consumidas em casa, em meio a bordados e outros passatempos. Até as primeiras décadas do século XIX, é provável que a maior parte dos romances lidos fossem traduções de obras estrangeiras de pouco fôlego, como as que José de Alencar se refere em sua autobiografia $^{13}$. Já em meados do século, o repertório se estendia, de acordo com os missionários protestantes Daniel Paris Kidder e James C. Fletcher, a "novelas de Balzac, Eugenio Sue, Dumas pai e filho, George Sand, em intrigas de pacotilhas e folhetins dos jornais" ${ }^{\prime 4}$. De uma forma ou de outra, o tempo livre e a maior possibilidade de instrução das mulheres de elite no século XIX, foram responsáveis pela criação de um público leitor feminino suficientemente numeroso para, segundo Laurence Hallewell, "alterar o equilíbrio do mercado" $"$. De acordo com Maria Angela D'Incao:

As leituras animadas pelos encontros sociais, ou feitas à sombra das árvores ou na mornidão das alcovas, geravam um público leitor eminentemente feminino. A possibilidade do ócio, entre as mulheres de elite incentivou a absorção de novelas românticas e sentimentais consumidas entre um bordado e outro, receitas de doces e

13 Em Como e Porque Sou Romancista, Alencar descreve as leituras que fazia quando jovem à mãe, à tia e amigas, enquanto estas se ocupavam com trabalhos de costuras. Segundo o autor: "nosso repertório romântico era pequeno: compunha-se de meia dúzia de obras entre as quais primavam a Amanda e Oscar, Saint-Clair das Ilhas, Celestina e outras que não me recordo". ALENCAR, J. Campinas: Pontes, 2005, p.29.

14 Apud. HAHNER, June E. A Mulher no Brasil, p. 56. Rio de Janeiro: Editora Civilização Brasileira, 1978.

15 HALLEWELL, Laurence. O Livro no Brasil: sua história. São Paulo: T.A. Queirós: Edusp, 1985, p.87 
confidências entre amigas"16

A maior liberdade que era oferecida à mulher burguesa no século XIX, no entanto, exigia maior controle moral. Com a vigilância familiar afrouxada, mas a conduta submetida aos olhos da sociedade, foi preciso que a mulher aprendesse a se comportar. Assim, com a ascensão da moral burguesa e o incentivo da política higienista, um novo paradigma de feminilidade surgia: a beleza, o recato, a constituição moral, passavam a se sobrepor às estirpes e linhagens. Em contraposição ao casamento nos moldes coloniais que se fundamentava inteiramente em interesses políticos e econômicos surgia, aos poucos, o casamento "por amor", isto é, a união parcialmente voluntária de indivíduos. A delicadeza era incentivada já que o futuro da mulher dependia, em grande parte, do poder de seus encantos. A virgindade - garantia sine qua non da honra e da pureza feminina - já altamente valorizada na colônia, tornava-se, cada vez mais, um requisito fundamental, para assegurar o prestígio da noiva dentro do mercado matrimonial ${ }^{17}$.

É importante ressaltar que a nova concepção de união "por amor" que, até certo ponto, permitia a escolha pessoal dos cônjuges baseada em interesses físicos e afetivos, era também, como observa Jurandir Freire, parte do projeto encampado pela medicina higienista, que buscava disciplinar o sexo por meio do combate às relações fora do casamento e, em especial, às práticas consideradas "antinaturais": a masturbação, a prostituição e o homossexualismo. Além disso, uma vida conjugal amorosa e tranquila, supostamente proporcionada pela união voluntária, era vista pelos médicos como essencial para a constituição de uma descendência saudável, moralmente bem instruída, que pudesse melhor atender aos interesses da Nação. Desta forma, ao enfatizar no imaginário dos cidadãos os benefícios do amor familiar e do cuidado com os filhos, a higiene acabou por acrescentar mais um elemento dentre as expectativas dirigidas à nova mulher burguesa: o papel de mediadora entre os filhos e o Estado. ${ }^{18}$

Na sociedade higienizada a mulher tornava-se a principal responsável por uma

16 D'INCAO, Maria Angela. "Mulher e Família Burguesa". In: DEL PRIORE, Mary (org.). História das Mulheres no Brasil, op cit , p. 229.

17 C. f. D'INCAO, Maria Angela. "Mulher e Família Burguesa”. In: DEL PRIORE, Mary (org.). História das Mulheres no Brasil, op cit.

18 C.f. COSTA, Jurandir Freire. Ordem Médica e Norma Familiar, op. cit. 
nação sadia. A figura da mãe zelosa e esposa devotada, já bastante difundida desde o Iluminismo, sobretudo nos discursos de Rousseau, passava a ser ainda mais valorizada no século XIX tanto pelos médicos quanto pela Igreja. No periódico religioso $O$ Apóstolo, que circulou pela capital fluminense entre os anos de 1866 a 1901, um artigo intitulado “A Fortaleza Cristã”, de 1967, apontava a salvação feminina por meio da maternidade:

Temos todos necessidade de grande energia para vencermos a nós mesmos, mas sobretudo a mulher [...] fraca por natureza, por compleição, por temperamento e por educação, entretanto é excitada por uma generosa dedicação, quando principalmente o amor de Cristo está em seu coração e a eleva à condição de mãe ${ }^{19}$.

Tornando-se mãe, a mulher livrava-se da mística diabólica que lhe era conferida, revestia-se novamente do manto da virtude, distanciava-se de Eva aproximando-se de Maria, encarnação do mito da salvação no imaginário judaico-cristão. Assim, a dupla imagem feminina calcificava-se definitivamente no imaginário oitocentista: se, por um lado, a figura de Eva simbolizava a essência maléfica, a tendência ao pecado supostamente presente em todas as mulheres reais; por outro lado, o arquétipo de Maria, encarnando a maternidade e a virgindade ao mesmo tempo, apresentava-se como um ideal, que, embora inacessível, deveria nortear o comportamento das mulheres que desejavam a salvação.

Fazendo coro com o discurso religioso, a identificação da mulher com a maternidade foi também um importante estratagema do processo normatizador da higiene. O incentivo ao amor materno era usado pelos médicos como forma de combate ao abandono de crianças e à amamentação recusada, práticas que contribuíam para o alto índice de mortalidade infantil na colônia. Por outro lado, a amamentação, os cuidados com a prole, e a responsabilidade pelo bem-estar familiar, ao mesmo tempo em que protegiam os interesses do Estado, regulavam a vida da mulher, mantendo-a dentro de casa. Com isso, estavam controlados os aspectos considerados negativos da sociabilidade feminina, entre eles: o mundanismo, a vaidade desmedida, o luxo

19 Anônimo. “A Fortaleza Christã”. In: O Apóstolo, 12 de maio de 1867. 
exagerado, a extravagância, a ociosidade e as demais condutas que desviavam a mulher das supostas obrigações de esposa. Assim, o ímpeto emancipatório recém-adquirido estava brecado. Libertada do confinamento doméstico, a mulher era confinada ao papel de mãe. Jurandir Freire, ao analisar o processo de formação da mãe higiênica, enxerga, portanto, um duplo movimento: "por um lado emancipação feminina do poder patriarcal; por outro, colonização da mulher pelo poder médico ${ }^{20}$ ".

Único elemento não consanguíneo a ter acesso à intimidade da nova família nuclear e isolada, o médico da família assumiu, ao longo do século XIX, um papel importante no ambiente doméstico: vigiava, diagnosticava, prescrevia, controlava, e exercia uma influência considerável, especialmente junto às mulheres. Michel Foucault, em sua História da Sexualidade, define a confissão como a matriz geral que rege a produção de todo o discurso sobre o sexo. Discurso esse que, ao longo do século XIX, passava articular-se "não mais àquele que fala do pecado e da salvação, da morte e da eternidade, mas ao que fala do corpo e da vida - o discurso da ciência” ${ }^{, 21}$. Com a figura do médico substituindo a do padre, a casa transformava-se em local permanente de inspeção de saúde e de vigilância moral. As mulheres dos sobrados, como observou Gilberto Freyre, iam encontrando "na confissão de doenças, de dores, de intimidades do corpo" uma maneira agradável de "desafogar-se da opressão patriarcal e da clerical."22 O comportamento dócil, embora firme, do médico, contrastava com o do padre, e tornava a relação mais humanizada. O "reprimir" dava lugar ao "cuidar", uma forma mais sutil, mas não menos eficiente, de dominação.

A obsessão pelo corpo, pelo sexo, pelo psiquismo, proporcionada pela higiene e respaldada pela mentalidade positivista cujos sopros já se faziam sentir em solo nacional em meados do século XIX, levava a ciência médica a associar o bem-estar físico ao emocional. As doenças que, como mencionado, já desde a colônia eram atreladas a questões de ordem moral, passaram a ser associadas às emoções. Paixões, ciúmes, cólera, medo, eram considerados os principais fatores causadores de febres, síncopes, contrações e enfermidades de todos os tipos. Dessa forma, os menores

20 COSTA, Jurandir Freire. Ordem Médica e Norma Familiar, op. cit., p. 255.

21 FOUCAULT, Michel. A História da Sexualidade, v. 1, op. cit, p.73.

22 FREYRE, Gilberto. Sobrados e Mucambos, op. cit., p. 237. 
movimentos do corpo e do intelecto passaram a ser observados, analisados, medicalizados. Aos poucos, a significação mística atribuída ao corpo feminino na colônia, era transformada em fisiologia.

Interessada em reforçar as distinções físicas e morais entre os sexos, a medicina higienista passava a relacionar a conduta social e emocional da mulher a uma suposta deficiência inata dos órgãos. A mulher passava a ser vista como um ser "frágil, carente de vontade, amolengada por suas qualidades naturais" que seriam: a fraqueza física e de caráter, "a minoridade intelectual, a falta de musculatura, a presença da menstruação" ${ }^{23}$. Até mesmo o instinto sexual passou a ser desmentido por alguns médicos, que passaram, paradoxalmente, a definir a mulher como um ser frígido, assexuado ou anestesiado sexualmente. Ao mesmo tempo, a figura da "mulher nervosa", da histérica, com uma sexualidade doentia e descontrolada, tornou-se peça chave de toda a medicina higienista.

Até meados do século XIX, o discurso médico sobre a histeria remontava ainda quase inteiramente aos conceitos de Platão e a outros autores da Antiguidade clássica, para os quais, como mencionado, o útero seria um animal oculto dentro do organismo feminino que teria "o apetite de fazer filhos" e que, quando contrariado, provocaria "angústias extremas" e "doenças de todos os tipos"24. A historiadora Magali Engel, em estudo que relaciona psiquiatria e feminilidade no século $\mathrm{XIX}^{25}$, afirma ter sido escrita em 1838, a primeira tese sobre histeria apresentada na Faculdade de Medicina do Rio de Janeiro. Nela, o autor, Dr. Rodrigo José Maurício Junior, definia a doença como “moléstia de que o útero é a sede”, e uma “afecção exclusiva da mulher”. Em 1857, segundo a historiadora, outro trabalho, de autoria do Dr. M. L Cordeiro, definia a histeria como "uma neurose dos órgãos genitais da mulher". Dois anos depois, em 1859, o médico Briquet, ainda buscando uma definição para o "mal histérico", qualifica-o como uma "neurose do anencéfalo" que, no entanto, mantinha vínculos

23 DEL PRIORE. Mary. In: DEL PRIORE, Mary (org.). História das Mulheres no Brasil, op. cit. 105.

24 PLATÃO. "Nas mulheres, o que chamamos de matriz ou útero é um animal dentro delas que tem o apetite de fazer filhos. E quando, apesar da idade propícia, permanece um longo tempo sem fruto, ele se impacienta e suporta mal este estado. Erra por toda a parte do corpo, obstrui as passagens do fôlego, impede a respiração, produz angústias extremas e produz outras doenças de todo o tipo.” Timeu. São Paulo: Instituto Piaget, 2004, p. 87.

25 ENGEL Magali. "Psiquiatria e Feminilidade". In: DEL PRIORE, Mary (org.).História das Mulheres no Brasil, op. cit., p. 343-344. 
estreitos com as qualidades "naturais" da mulher: "sensibilidade, emocionalidade, sentimentalismo". Assim, apesar das divergências encontradas nos diferentes estudos da época, Engel conclui que o conceito de histeria, de um modo geral, permanece, até meados do século XIX, se não diretamente ligado ao útero, ao menos associado às especificidades do corpo da mulher, e mais diretamente, à fisiologia sexual feminina.

Tal concepção aproximava-se bastante da mística presente no imaginário colonial, na medida em que, ao associar o distúrbio ao aparelho reprodutor da mulher, reforçava-se a mentalidade que desqualificava o corpo feminino como um organismo impregnado de sexualidade, ameaçador, perigoso, e que deveria ser domesticado. O sangue menstrual que antes, como mencionado, era visto pela Igreja como um veneno usado em feitiços, permanecia despertando a desconfiança dos médicos, na medida em que se apresentava, em quase todos os casos das mulheres diagnosticadas como histéricas, como o principal desencadeador do distúrbio. A gravidez também aparecia em grande parte dos relatos médicos, associada às doenças mentais. De uma forma ou de outra, o corpo feminino e seu funcionamento, permaneciam carregados de um estigma misterioso e assustador.

Com o tempo e o avanço da medicina, a concepção uterina da histeria perde força e o perfil da mulher histérica passa a ser redefinido e difundido a partir de um discurso científico mais elaborado. Ao final do século, a histeria seria quase consensualmente incorporada à esfera das doenças do sistema nervoso. No entanto, segundo Engel, "nem mesmo a contribuição da neurofisiologia, e as novas interrogações suscitadas pela histeria, romperiam com a tradição de associá-la à sexualidade feminina", e esta continuava sendo considerada indomável por excelência. Nas palavras da historiadora.

Para além das inúmeras controvérsias acerca das características da histeria enquanto doença, o perfil da histérica era traçado de um modo mais ou menos consensual: instável e imprevisível, seu caráter seria essencialmente marcado pelo desequilíbrio entre as "faculdades morais superiores e as paixões, instintos e desejos". Por isso, as mulheres histéricas eram consideradas perigosas. Assim, uma das dimensões do perigo representada pela histérica estava explicitamente associada à manifestação de uma sexualidade que, excessiva e 
pervertida, poderia escapar ao próprio controle do médico. ${ }^{26}$

Podemos perceber, portanto, que, no que tange à abordagem do corpo feminino, o discurso higienista difundido no Rio de Janeiro no século XIX não divergia completamente da mentalidade mágico-milagrosa presente na colônia. Ao contrário, no processo de transição que leva o adestramento da sexualidade feminina das mãos da Igreja para as mãos dos médicos é possível perceber uma convergência de discursos, um entrelaçamento de ideologias, que se reforçam mutuamente. Assim, o antigo discurso religioso que caracteriza a mulher como um ser misterioso e assustador que reunia dentro de si as sementes do Bem e do Mal, é caucionado pela higiene e ganha, segundo Engel, "nova roupagem e status de verdade científica". Ao mesmo tempo, se na perspectiva mística e sacramental da colônia a mulher era vista como um ser naturalmente destinado à maternidade, o discurso da ciência, como já foi demonstrado, compactuava com tal concepção, na medida em que, ao buscar definir uma normalidade que explicasse o destino biológico da mulher, exaltava a figura da mulhermãe, guardiã da família e base moral da sociedade.

Ambos os discursos apresentavam, portanto, uma alternância de modelos: a mulher era ao mesmo tempo vista como um ser impregnado de sexualidade, incontrolável, perigoso; e, paralelamente, como um ser débil, frágil, casto, quase assexuado. Anjo ou demônio, Eva ou Maria, “mulher-mãe” ou "mulher nervosa”, ela permanece a personificação do incômodo outro que desperta fascínio e terror.

26 ENGEL Magali. "Psiquiatria e Feminilidade”. In: DEL PRIORE (org.). A História das Mulheres no Brasil, op. cit, p.349. 


\section{Os Limites do Dizível.}

"A palavra foi dada ao homem para ocultar seu pensamento"

(Gabriel Malagrida) 


\subsection{A questão da autoria}

Lucíola, quarto romance de Alencar e primeiro dos "perfis de mulher", foi publicado em 1862, logo após uma conturbada passagem do escritor pela atividade teatral. A obra veio a público clandestinamente e, confiando-se no relato do autor, é possível inferir, como observou Luis Filipe Ribeiro ${ }^{27}$, que sua autoria permaneceu oculta até pelo menos a terceira edição publicada dez anos depois.

Em 1862 escrevi Lucíola, que editei por minha conta e no maior sigilo. Talvez não me animasse a esse cometimento, se a venda da terceira edição ao Sr. Garnier, não me alentasse a confiança, provendo-me de recursos para os gastos da impressão. ${ }^{28}$

Inúmeros são os motivos que podem ter levado Alencar a optar pelo anonimato. O uso de pseudônimos era muito comum na época, já que a opção por imprimir verossimilhança realista a seus enredos obrigava boa parte dos escritores a camuflaremse por trás das figuras de "relatores" ou "editores" de fatos supostamente reais. A ficção, considerada atividade frívola e perniciosa, passatempo de ociosos, corruptora de costumes - sobretudo junto ao eleitorado feminino - era atividade pouco recomendada a alguém que, como Alencar, ambicionava a carreira política. Além disso, havia, sem dúvida, até esse momento da obra do autor, certa insegurança em relação à recepção que o levava a assumir a autoria de seus textos apenas após ter a garantia de um bom acolhimento por parte do público leitor e da elite intelectual. ${ }^{29}$ Medo de manchar a trajetória política com o exercício da literatura, ou medo de prejudicar a recepção de suas obras por conta da personalidade já reconhecidamente ácida? De uma forma ou de outra, a questão da autoria nos romances de Alencar é, também, parte de uma estratégia discursiva que organiza estruturalmente as narrativas, muitas vezes interligando-as.

Em Cinco Minutos (1856), primeira aventura literária de Alencar, um narradorpersonagem não identificado relata à prima, denominada apenas pela inicial $\mathrm{D}$, uma

27 RIBEIRO, Luis Filipe. Mulheres de Papel: um estudo do imaginário em José de Alencar e Machado de Assis. Niterói, R.J: Eduff, 1996.

28 ALENCAR, José de. Como e Porque Sou Romancista. Campinas: Pontes, 2005, p.66.

29 Assim sugere João Roberto Faria ao analisar a dramaturgia de Alencar. FARIA, João Roberto. José de Alencar e o Teatro. São Paulo: Perspectiva, 1987 
breve intriga amorosa de trama fácil e desenlace previsível. "É uma história curiosa a que vou lhe contar, minha prima. Mas é uma história e não um romance" ${ }^{30}$, esclarece o narrador no primeiro capítulo. Em A Viuvinha $(1857)^{31}$, obra de enredo igualmente simples, a moldura verossímil se mantém. Desta vez, o narrador-personagem da primeira novela, ainda em relato dirigido à prima, transforma-se em testemunha de uma história de amor acontecida entre duas outras personagens: Jorge e Carolina, vizinhos, e amigos íntimos do suposto emissor: “[...] as nossas famílias se visitam com muita frequência [...] Isso explica, D, como soube dos incidentes dessa história" ${ }^{, 32}$. Os dois "romancetes", publicados inicialmente em folhetim, foram aparentemente ignorados pela crítica, mas bem acolhidos pelo público leitor. Em relação a Cinco Minutos, o próprio Alencar nos oferece uma ilustração de como assinantes e não assinantes reivindicavam com prontidão seus exemplares e "insistiam em comprar a brochura, somente destinada à distribuição gratuita entre os subscritores do jornal”33.

Aborrecido pelo silêncio da imprensa, mas animado por ter, com Cinco Minutos, alcançado "leitores espontâneos, não iludidos por falsos anúncios", Alencar decidiu arriscar-se em obra de maior fôlego: O Guarani (1857), romance cuja popularidade é atestada por Visconde de Taunay nas famosas Reminiscências ${ }^{34}$. A empolgante história de amor de Ceci e Peri veio a público também anonimamente, mas o foco narrativo se deslocava. Desta vez, o narrador das duas primeiras obras enviava à D. - a mesma misteriosa prima das novelas anteriores - um suposto manuscrito que havia copiado com a ajuda de Carlota (a heroína da primeira novela).

Minha prima. - Gostou da minha história e pede-me um romance; acha

30 ALENCAR, José de. Cinco Minutos. In: Obra Completa, vol. I. Rio de Janeiro: Aguilar, 1965, p. 153.

31 Estamos trabalhando com a hipótese de que a Viuvinha seja a segunda obra escrita por Alencar (dentre as que vieram a público na época), embora sua publicação em folhetim tenha se iniciado, como notou Raymundo de Magalhães Jr., após $O$ Guarani. Ver: MAGALHÃES JR., Raimundo. José de Alencar e sua Época. Rio de Janeiro: Lisa - Livros Irradiantes, [s.d], p. 77.

32 ALENCAR, José de. A Viuvinha. In: Obra Completa, vol. I, op. cit, 228.

33 Idem, Como e Porque Sou Romancista, op. cit. p. 56.

34 .."O Rio de Janeiro, para assim dizer, lia o Guarani [...]. Quando a São Paulo chegava o correio, com muitos dias de intervalo então reuniam-se muitos estudantes numa república em que houvesse qualquer feliz assinante do Diário do Rio para ouvir absortos e sacudidos de vez em quando por um frêmito, a leitura feita em voz alta por algum deles que tivesse órgão mais forte. E o jornal era depois disputado com impaciência e, pelas ruas, se viam agrupamentos em torno dos fumegantes lampiões da iluminação pública de outrora - ainda ouvintes a cercarem, ávidos de qualquer improvisado leitor." TAUNAY, Visconde de. In: Reminiscências.São Paulo: Comp. Melhoramentos, 1923, p. 85, 86. 
que posso fazer alguma coisa nesse ramo da literatura. Engana-se. [...] Entretanto, para satisfazê-la, quero aproveitar as minhas horas de trabalho em copiar e remoçar um velho manuscrito que encontrei em um armário desta casa, quando a comprei [...].

Envio-lhe a primeira parte, que eu e Carlota temos decifrado nos longos serões das nossas noites de inverno, em que escurece aqui às cinco horas ${ }^{35}$

É “ficção dentro da ficção”, como aponta o crítico João Alexandre Barbosa ${ }^{36}$. No entanto, com a mudança de foco, a narrativa se libertava da posição de história vivida ou testemunhada e podia assumir o caráter fantasioso, para o qual, segundo boa parte da crítica, Alencar demonstraria mais talento.

Neste caso, no entanto, é importante notar que o prólogo que sustentava o pseudônimo apareceu apenas na primeira edição publicada em folhetim, sendo suprimido nas demais. A popularidade da obra é certamente o principal fator que levou Alencar a desfazer o engodo assumindo a autoria, ao mesmo tempo em que a própria narrativa assumia-se definitivamente como ficção.

Ainda em 1857, iniciou-se um período no qual Alencar decidiu se dedicar quase que exclusivamente ao teatro. "Rio de Janeiro, Verso e Reverso", sua primeira peça, recebeu, além dos aplausos do público, exaltados elogios da elite letrada. Alencar insistia no anonimato, mas, aparentemente motivado pela boa recepção da comédia, consentiu que seu nome fosse publicado à altura da terceira apresentação. A peça seguinte, "O Demônio Familiar", submetida à censura do Conservatório Dramático como a anterior, recebeu ainda mais altos elogios, apesar de algumas ressalvas, e teve a sua autoria assumida antes mesmo de chegar aos palcos. Mais seguro em função dos dois êxitos anteriores, Alencar publicou e assinou sua terceira peça "O Crédito" cuja temática - a especulação financeira na Corte fluminense - não agradou. Os teatros ficaram vazios e os elogiosos pareceres do conservatório não foram suficientes para livrar o autor do sentimento de fracasso.

Decepção maior Alencar experimentou no ano seguinte, em 1858, com a peça

35 ALENCAR, José de. Prólogo de O Guarani. .São Paulo: Ática, 1990.

36 BARBOSA, João Alexandre. "Leitura de José de Alencar". In: Introdução a "O Guarani". São Paulo: Ed. Ática, [s.d]. 
"As Asas de um Anjo", espécie de prelúdio de Lucíola, romance escrito quatro anos depois. O tema, sem dúvida delicado, da regeneração da cortesã - já bastante conhecido pelos leitores e espectadores europeus - não seria tão naturalmente acolhido em solo nacional, impregnado de valores católicos. A história de Carolina, a jovem rebelde, porém de bom coração, arrastada ao vício por um sedutor, causou polêmica e, apesar de já ter conseguido a aprovação do conservatório - sempre bastante complacente com o autor - foi tirada dos palcos pela polícia sob a acusação de imoralidade.

A julgar pelas críticas publicadas nos jornais da época, a peça incomodava principalmente por dois fatores: a descrição pormenorizada do universo de depravação no qual Carolina mergulha - culminando com a forte cena em que a heroína aparece sendo seduzida pelo próprio pai - e a tentativa de reabilitação da personagem que acontece no epílogo, quando lhe é oferecida a possibilidade de um casamento. Profundamente incomodado pela censura, Alencar esforçou-se para explicar a obra por meio de textos críticos publicados no Diário do Rio de Janeiro nos quais enfatizava o caráter edificante da peça, que teria como propósito "alertar os pais de família sobre a necessidade de cuidarem da educação moral de seus filhos." ${ }^{37}$ Mas a defesa foi em vão: a obra ficou fora dos palcos até 1869 , quando, a partir de um esforço do próprio autor, então Ministro da Justiça, voltou à cena em quatro apresentações que foram, segundo João Roberto Faria, "friamente a acolhidas" 38 . O embate com os censores, a polêmica gerada, as constantes tentativas de justificar-se extenuaram o dramaturgo que, apesar das palavras de incentivo vindas de intelectuais e amigos, saiu do episódio profundamente abalado.

Não é de se surpreender, portanto, que em Lucíola, primeiro romance publicado após a experiência nos palcos, Alencar voltasse a optar pelo anonimato, que se sustentou, como já foi dito, pelo menos até as três primeiras edições custeadas pelo próprio autor. A insistência na temática da regeneração da mulher perdida, que já se mostrara problemática, certamente acirraria novamente os ânimos e soaria como despeito. Para o homem público que assumia frequentemente para si a tarefa de

37 ALENCAR, José de. Artigo publicado no Diário do Rio de Janeiro em 22 de junho de 1858. In: Obra Completa, v. IV. Rio de Janeiro: José Aguilar, 1960.

38 FARIA, João Roberto. José de Alencar e o Teatro, op. cit, p. 92. 
reformar os costumes e esforçava-se em "respeitar a moral pública, tanto nas palavras, quanto nas ações" 39 , a pecha de escritor "imoral" era bastante comprometedora.

Não obstante, a obra repetiu a trajetória dos três romances anteriores: conquistou o público espontaneamente, sem precisar se apoiar no chamariz da imprensa. Segundo Alencar:

\begin{abstract}
Apesar do desdém da crítica de barrete, Lucíola conquistou seu público, e não somente fez caminho como ganhou popularidade. Em um ano esgotou-se a primeira edição de mil exemplares, e o Sr. Garnier comprou-me a segunda, propondo-me a tomar em iguais condições outro perfil de mulher que eu então gizava. ${ }^{40}$
\end{abstract}

A segunda edição de Lucíola, impressa em Paris, veio a público apenas três anos depois, em 1865. Ainda assim, a popularidade deste primeiro "perfil" pode ser considerada significativa se levarmos em consideração a escassez de leitores do Rio de Janeiro oitocentista, cuja população alfabetizada, em 1872, não ultrapassava os $16 \%{ }^{41}$. De acordo com Hélio de Seixas Guimarães, "apenas títulos muito bem-sucedidos chegavam à segunda edição, que podia demorar vinte ou trinta anos" ${ }^{42}$. A exceção, segundo Hélio, se deu com romance A Moreninha, de Macedo, reconhecido fenômeno de vendas da época, e uma das poucas obras a ter as duas primeiras edições lançadas em dois anos consecutivos.

Pouco mais de um ano depois que a história de Lúcia vem a público, Machado de Assis, ao comentar a recepção de Diva, confirma o êxito sugerido por Alencar em relação ao sucesso do primeiro perfil: "É um romance do autor de Lucíola. Todos se lembram do barulho que fez Lucíola. Terá este a mesma fortuna? Ouso duvidar. Lucíola tinha mais condições de popularidade"43 Ao que tudo indica, o "barulho" a que Machado se refere diz respeito exclusivamente ao público leitor e não à crítica. Esta, fazendo jus às reclamações do autor, pouco mencionou o romance. Em verdade, as

39 ALENCAR, José de. Artigo publicado no Diário do Rio de Janeiro em 22 de junho de 1858. In: Obra Completa, v. IV. Rio de Janeiro: José Aguilar, 1960.

40 ALENCAR, José de. Como e Porque sou Romancista. op. cit, p. 67.

41 GUIMARÃES, Hélio de Seixas. Os Leitores de Machado de Assis. São Paulo: Edusp, 2005, p. 66.

42 Ibidem, p.66.

43 Publicado na imprensa acadêmica, a 17 de abril de 1864 apud. MAGALHÃES JR. José de Alencar e sua Época. Rio de Janeiro: Livros Irradiantes, [s.d]. 
alusões à obra nos periódicos da época limitaram-se a uma nota, publicada no Jornal do Comércio: "Saiu à luz um livro intitulado Lucíola ${ }^{44 ", ~ a l e ́ m ~ d e, ~ s e g u n d o ~ o ~ a u t o r, ~}$ "algumas poucas linhas" em uma publicação semanal, que "davam a notícia do aparecimento do livro, e ao mesmo a de estar ele eivado de galicismos ${ }^{45}$ ".

Boa parte dos biógrafos e comentadores da obra de Alencar aponta um aparente paradoxo entre as queixas do autor quanto ao silêncio da imprensa e o fato de ter optado por publicar a obra anonimamente: "Ora, se ele mesmo assume haver publicado a obra em sigilo [...] será sua zanga a posterior, assim tão verdadeira?"46 A meu ver, parece claro que, escondendo a autoria, Alencar almejava permitir que a obra falasse por si, isto é, que conquistasse a opinião pública literária, autonomamente, sem o aparato de um nome já bastante conhecido. Assim, além de proteger a própria reputação, o autor evitaria que a recepção do romance fosse contaminada pelas polêmicas políticas e literárias nas quais havia se envolvido ${ }^{47}$. $\mathrm{O}$ argumento da autonomia do romance em relação à figura do autor aparece posteriormente na "Carta a D. Paula de Almeida", texto crítico em defesa de Senhora, também publicado no Jornal do Comércio.

\begin{abstract}
Não pergunto à rosa que me enfeita e à seda que me veste, qual o canteiro ou o tear que produziu essas maravilhas. Da mesma forma não inquiro do livro que cérebro o pensou, que mão o escreveu. ${ }^{48}$
\end{abstract}

A personagem que assina o texto acima mencionado é Elisa do Vale, leitora fictícia, criada por Alencar para defender a si mesmo e a obra das acusações sofridas pela crítica (prefigurada em outra suposta leitora: “D. Paula de Almeida”). O jogo criado pelo romancista nesta carta abre espaço para pensarmos outro lado do estratagema que parece estar por trás do anonimato de Lucíola: ao fazer com que a obra

44 ALENCAR, José de. Como e Porque sou Romancista, op. cit, p. 66.

45 ALENCAR, José de. Pós-Escrito de Diva. In: Obra Completa, vol I, op. cit, p. 401.

46 RIBEIRO, Luis Filipe. Mulheres de Papel, op cit, p. 86. Este também é o questionamento de Luis Viana Filho em A Vida de José de Alencar. Rio de Janeiro: José Olympio, 1979.

47 A essa altura, Alencar, sob o pseudônimo de Ig., já havia se envolvido em polêmica com o imperador D. Pedro II e Araújo de Porto Alegre a respeito do poema "A Confederação dos Tamoios", de Gonçalves de Magalhães. Ver: CASTELLO, José Aderaldo. A Polêmica sobre a Confederação dos Tamoios”. São Paulo: FFLC-USP, 1953.

48 ALENCAR, José de. "Carta a D. Paula de Almeida”. In: José de Alencar, Obra Completa. - vol. I. Rio de Janeiro: Aguilar, 1959, p. 354. 
falasse por si, Alencar buscaria desenvolver uma cumplicidade com os leitores, delegando-lhes a tarefa de julgar o romance antes que a imprensa relacionasse a obra ao autor. A boa aceitação da obra pelo público leitor funcionaria, portanto, como uma resposta prévia aos possíveis censores. (Se o livro foi bem aceito pelo público leitor, como poderia ele considerado imoral?) Para tanto, Alencar conta ainda, no paratexto da obra, com G.M., a personagem que funciona como ponte entre o autor e o público, e que contribui para tal cumplicidade.

\subsection{A cumplicidade da interlocutora.}

Em Lucíola, Alencar volta a utilizar o foco narrativo em primeira pessoa como em suas duas primeiras novelas, mas desta vez a estratégia discursiva é mais elaborada. Paulo, o narrador-personagem, confidencia, por meio de cartas, suas experiências amorosas com Lúcia a uma senhora denominada pelas iniciais G. M. que, por sua vez, encarrega-se de organizar os relatos e construir o romance, dando-lhe, inclusive, o título. Em nota introdutória endereçada "ao autor", G. M. afirma:

Reuni as suas cartas e fiz um livro.

Eis o destino que lhes dou: quanto ao título, não me foi difícil achar. $\mathrm{O}$ nome da moça, cujo perfil o senhor desenhou com tanto esmero, lembrou-me o nome de um inseto. ${ }^{49}$

Com esta armação discursiva, Alencar, mais uma vez, procura prender a atenção do leitor com a ilusão de verdade, conforme a convenção da época, abrindo mão, contudo, da moldura do romance epistolar, já que a edição de G. M. teria eliminado as marcas de correspondência e o caráter fracionado que caracterizam esse tipo de narrativa. Assim, a história de amor entre Paulo e Lúcia chega ao leitor na forma de um único longo relato, ininterrupto, em tom confessional e, sobretudo, analítico. As recordações de Paulo vêm a público retrospectivamente e passam a compor um quebracabeça cuja principal função é estudar o caráter de Lúcia, desvendá-la, decifrá-la aos

49 ALENCAR, José de. Lucíola. In: José de Alencar: Obra Completa, vol. I. Rio de Janeiro: José Aguilar, 1965, p. 229. Doravante apenas Lucíola. 
olhos da destinatária e, em última estância, do leitor.

Paulo e G. M., a propósito, compõem a estrutura discursiva de duas outras narrativas de Alencar publicadas posteriormente: Diva, em que Paulo relata à mesma senhora uma história de amor que lhe foi contada durante uma viagem por um conhecido: Augusto, apaixonado por uma jovem cujo comportamento instável assemelha-se ao de Lúcia; e Escabiosa-Sensitiva, obra inacabada, em que Paulo envia a G. M. a transcrição editada do relato de Sá - também seu amigo e personagem de Lucíola - este último, interessado em desvendar o caráter de Elisa, por quem também havia se apaixonado. É possível afirmar, portanto, que a G.M serve também para interligar três dos quatro "perfis de mulher", separando-os das demais obras e mostrando que formam, como aponta Maria Cecília Queiroz, "uma classe dentro de um gênero" ${ }^{, 50}$.

Em Lucíola, o diálogo entre o remetente e a destinatária ocupa considerável espaço na obra. A voz de G. M. aparece unicamente na nota introdutória já mencionada, em que assume para si a responsabilidade pela edição do livro, mas os momentos em que Paulo se dirige diretamente à sua interlocutora pontuam esporadicamente a narrativa como um todo, embora concentrem-se, de maneira mais direta, nas páginas de abertura e fechamento da narrativa. Nelas, Paulo faz menção a encontros anteriores entre ele e a destinatária: "a senhora estranhou, na última vez em que estivemos juntos"; e enfatiza o caráter pessoal e íntimo da correspondência: "estas páginas foram escritas unicamente para a senhora." ${ }^{, 51}$ Com esse jogo, Alencar, além de reforçar a credibilidade do enredo, induz o leitor a um olhar voyerista, oferecendo-lhe a possibilidade de devassar a consciência íntima do signatário, tendo acesso a seus segredos.

Segredos de polichinelo, é necessário reconhecer, pois a publicação da obra por G. M, com o consentimento de Paulo, se não abala o caráter confidencial da narrativa, pelo menos evidencia, como aponta a professora Regina Lúcia Pontieri, a ambiguidade latente do jogo criado por Alencar: "confidência que deixa entrever o desejo de

50 PINTO, Maria Cecília Queiroz de Moraes. Alencar e a França - perfis. São Paulo: Annablume, 1999. p. 62. Em Senhora, último dos perfis, publicado em 1875, a figura da destinatária desaparece, embora o autor continue se apresentando como mero editor de uma história que lhe foi relatada.

51 Luciola, p. 231 e 331, respectivamente. 
inconfidência" ${ }^{, 52}$. Segundo Pontieri, neste como nos demais perfis, narrativa e heroína se revelam e se constroem justamente dentro do jogo do mostrar e esconder. A opção de Alencar pela narração em primeira pessoa, sob a forma de confissão escrita, faz parte da estratégia discursiva que contribui para esse jogo. $\mathrm{O}$ foco narrativo limitado a uma perspectiva pessoal, particular, a perspectiva do indivíduo que vive os fatos narrados, retira do leitor a possibilidade de ter acesso aos pensamentos da protagonista, o que reforça na narrativa o caráter de desvendamento. Assim, o leitor é convidado a embarcar junto com o narrador-personagem na aventura de decifração da heroína.

É importante ressaltar, no entanto, que a importância da destinatária, em Lucíola, não se limita a "dar corpo" às recordações da Paulo. Em verdade, como observou Valéria de Marco, em $O$ Império da Cortes $\tilde{a}^{53}$, o principal papel de G. M. tem dimensão moral e transcende os limites do texto literário. Na posição de quem lê em primeira mão os escritos de Paulo, e organiza-os para que transformem-se em livro, G. M. exerce, acima de tudo, uma função interpretativa' na medida em que analisa os fatos narrados, e emite opiniões. Vejamos o restante da nota em que a destinatária se dirige "Ao autor":

Lucíola é o lampiro noturno que brilha de uma luz tão viva no seio da treva e à beira dos charcos. Não será a imagem verdadeira da mulher que no abismo da perdição conserva a pureza d'alma?

Deixem que raivem os moralistas. A sua história não tem pretensões a vestal. É musa cristã: vai trilhando o pó com os olhos no céu. Podem as urzes do caminho dilacerar-lhe a roupagem: veste-a a virtude.

Demais, se o livro cair nas mãos de alguma das poucas mulheres que lêem neste país, ela verá estátuas e quadros de mitologia, a que não falta nem o véu da graça, nem a folha da figueira, símbolos do pudor no Olímpio e no Paraíso terrestre.

Novembro de 1861.

$$
\text { G.M }^{54}
$$

A primeira postura tomada por G. M. nesta nota é a de defender o caráter de Lúcia, enfatizando-lhe a pureza de alma que resiste à ação corrosiva do meio: "Não será a imagem verdadeira da mulher que no abismo da perdição conserva a pureza d'alma? ".

52 PONTIERI, Regina Lucia. A Voragem do Olhar. São Paulo: Perspectiva, 1988, p.19.

53 C.f. DE MARCO, Valéria. São Paulo: Martins Fontes, 1986.

54 Lucíola, p. 229. 
Em seguida, a destinatária assume uma função ainda mais peculiar: defender o autor do romance contra uma possível acusação de imoralidade: "Se o livro cair nas mãos de alguma das poucas mulheres que leem neste país, ela verá estátuas e quadros de mitologia, a que não falta nem o véu da graça, nem a folha da figueira, símbolos do pudor no Olímpio e no Paraíso terrestre.”

A estratégia é compreensível, e já foi analisada por Luis Filipe Ribeiro ${ }^{55}$ no trabalho já referido. Alencar, demonstra Luis Filipe, é um escritor perfeitamente consciente dos códigos e valores da sociedade em que vive. É natural que prepare seus leitores - e sobretudo leitoras - para a temática, um tanto quanto delicada para os padrões da época. A experiência anterior com a censura teatral certamente serviria para alertá-lo neste sentido. Desta forma, o autor se utiliza da cumplicidade com a interlocutora para amenizar a escolha - ou, melhor dizendo, a insistência - no tema, assim como para, já na introdução do livro, inocentar a cortesã, alçada a priori ao patamar de divindade.

A armação ficcional desenvolvida por Alencar é reforçada, inclusive, pela caracterização física e moral da interlocutora: uma senhora respeitável, cuja confiabilidade é garantida pela idade avançada - sugerida pela alusão aos cabelos brancos e à presença da neta - e pelo "tato sutil" necessário para "julgar numa questão de sentimentos". Uma "mulher superior", cujo julgamento seria difícil de contestar. Vejamos: se o texto acima fosse inserido no discurso de Paulo, personagem diretamente envolvida e cúmplice da história, as afirmações relacionadas à heroína soariam tendenciosas; se fosse assinado pelo autor verdadeiro, a defesa da narrativa perderia força. Vindo de uma senhora idosa e sem qualquer envolvimento com os episódios narrados, não há como negar-lhe credibilidade. Assim, G.M., munida da autoridade que lhe é conferida pelo autor, pretende antecipar o julgamento do leitor, inocentando a cortesã e a obra, antes que a narrativa se inicie.

Voltando aos conceitos trabalhados por Michel Foucault, na História da Sexualidade, é importante lembrar que, para o autor, a confissão apresenta-se como um ritual de discurso que se desenvolve em uma relação de poder, já que necessita da figura

55 C.F. RIBEIRO, Luis Filipe. Mulheres de Papel, op. cit. 
"de um parceiro, uma autoridade", que, não apenas recebe a confissão, mas "impõe-na, avalia-a e intervém para julgar, punir perdoar, consolar, reconciliar..."56. Em Lucíola, G. M. representaria essa figura de autoridade na medida em que, ao receber a confissão, julga e absolve, não o confidente, mas o autor verdadeiro ${ }^{57}$.

Alencar escrevia, como se sabe, também - e e, talvez, principalmente - para mulheres, que, como mencionamos no primeiro capítulo, com mais tempo livre e sem acesso à educação formal, passaram a compor, segundo os testemunhos da época, uma considerável parcela do público consumidor de romances. Assim, é possível dizer que G.M. se apresenta também - e sobretudo - como uma representação desse incipiente público leitor feminino, ao qual boa parte dos escritores do século XIX tentava se adequar. Pode-se considerar, portanto, seguindo mais uma vez a sugestão de Valéria de Marco, que G.M. aparece na obra como uma espécie de "personagem-leitora", representação fictícia do público a quem o autor se dirigia.

Assim como a Elisa do Vale da carta já mencionada, G.M funciona como a representação de uma "boa leitora" ou "leitora ideal": aquela que, por possuir sensibilidade, experiência e virtude (o "tato sutil"), é capaz de perceber, como aponta Luis Filipe Ribeiro, a “dimensão ética oculta” por trás máscara da cortesã. Dimensão

56 FOUCAULT, Michel. A História da Sexualidade.- v. 1, op. cit., p.71.

57 À guisa de hipótese, talvez seja possível associar as inicias escolhidas para dar nome à confidente de Paulo às do padre Gabriel Malagrida: religioso italiano que, ao vir para o Brasil em meados do século XVIII, inicia em Pernambuco um convento para prostitutas "convertidas". Malagrida é citado pelas mesmas iniciais na peça "O Jesuíta", escrita por Alencar em 1861, ano anterior ao da publicação de Lucíola. Na peça, as iniciais G. M. aparecem em um misterioso manuscrito enviado aos missionários no Brasil para alertá-los quanto aos planos de expulsão da Companhia de Jesus, elaborados por Marquês de Pombal:

Juan: Isso agora é outro cantar. Atendei. Vi no pergaminho, como vos estou vendo, o seguinte: na primeira linha três letras iniciais - um M, um T, um P. Depois esta data: Catorze de novembro - e assinado: G. $\mathbf{M}$.

Samuel: Gabriel Malagrida!

D. Juan: Justo!

A alusão pode, evidentemente, ser aleatória, mas parece ser possível pensar que ao repetir as iniciais para dar nome à interlocutora, Alencar estivesse utilizando-se da reputação do padre para autorizar o argumento da sua obra: a possibilidade de redenção da mulher perdida. A relação, no entanto, pode ter passado despercebida pela crítica, já que a peça só chegou aos palcos quatorze anos depois de escrita, isto é, em 1875. ALENCAR, José de. "O Jesuíta”. In: Teatro Completo, vol. II. Rio de Janeiro: Funarte, 1977, p. 462. (grifo meu) 
esta que, segundo Ribeiro, "se não justificava o comportamento socialmente condenável da heroína", ao menos "tornava-o explicável e, com isso, educativo"

Como já mencionado, Alencar é um escritor que assume para si a tarefa de reformar os costumes. Todas as suas obras, e sobretudo as peças teatrais, trazem um firme propósito pedagógico que se fundamenta no tripé “divertir-edificar-intruir", com o qual, segundo Antonio Candido, o romance, em seus primórdios, buscou legitimar-se e adquirir prestígio frente à opinião erudita ${ }^{59}$. Fiel ao preceito do dulce e utile horaciano, Alencar esforçava-se por fazer com que suas obras prendessem a atenção do leitor com um enredo agradável, por trás do qual se escondiam ensinamentos de ordem moral e religiosa que despertassem o horror ao vício e reforçassem as normas da ideologia dominante. Por outro lado, nos seus romances urbanos e nas peças de teatro, o autor, na esteira de Dumas, Feuillet e Balzac, tentava estilizar certo realismo buscando reproduzir a vida social na Corte dando ênfase em seus aspectos corrosivos. O impasse que Alencar, em Lucíola, tenta resolver (e que não havia conseguido com a peça censurada) é: como sustentar a temática da heroína de alma pura e essência ética incorruptível mostrando-a, em boa parte da narrativa sucumbindo ao vício e, ainda assim, esquivar-se da acusação de corruptor de costumes?

A solução - que se dará definitivamente no final da narrativa pela separação entre corpo e alma - passa também pela criação da personagem-leitora que, sendo construída de acordo com os anseios do próprio autor, transforma-se em uma aliada em defesa do seu ponto de vista.

Nesse sentido, torna-se importante destacar o trabalho de Maria Helena Vicente Werneck: Mestra: entre agulhas e amores - a leitora do século XIX na literatura de Machado e Alencar que analisa o papel da leitora fictícia no romance brasileiro do século XIX. Refutando os argumentos de uma parcela da crítica que caracterizava o público leitor feminino como um público pouco exigente e, portanto, responsável pela má qualidade da literatura da época, a autora defende a ideia de que haveria, ao contrário, na obra de Alencar uma tentativa de resgate e valorização da leitora que

58 RIBEIRO, Luis Filipe. Mulheres de Papel, op. cit. p. 91,92.

59 C.f. CANDIDO, Antonio. "A Timidez do Romance". In: Educação pela Noite \& outros ensaios. São Paulo: Ed. Ática, 1987. 
deveria, no entanto, ser instruída para agir de maneira crítica, participativa, emitindo opiniões que fossem capazes de "atravessar as barreiras da casa, e influenciar a opinião pública”. Para Werneck, portanto, a criação G. M. - leitora fictícia que interpreta a confissão - se apresenta na obra de Alencar como uma "madura técnica voltada não só para provocar afeto, mas também para estimular a crítica e mobilizar o sujeito criativo que existe em cada mulher que lê" ${ }^{\wedge}$. Preparando o leitor para o assunto a ser abordado, absolvendo a heroína antes que a narrativa se inicie, posicionando-se, enfim, como um guia que direciona a leitura da obra evitando conclusões precipitadas, G.M. funcionaria, segundo Werneck, como uma espécie de "duplo" do autor que, por sua vez, travestido de narrador, dirigir-lhe-ia um "tratamento tutelar" comunicação entre o texto e a leitora.

De uma maneira ou de outra, é sob a vigilância do autor que os leitores e leitoras devem andar. Alencar, cioso de proteger sua reputação como homem público, respeitador dos códigos sociais, direciona a leitura da obra, como demonstra Werneck, e antecipa o julgamento do leitor impedindo a livre interpretação. Como um "pai” que protege o filho, acompanha a obra de perto, cuidando para que ela não seja vítima de uma análise equivocada. Nesse sentido, há também, em Lucíola, uma constante preocupação com a linguagem e uma insistência em justificar a maneira de contar. Trata-se da pena "calma e refletida" à que Paulo alude na introdução à G.M.

\subsection{A pena calma e refletida.}

$\mathrm{O}$ cuidado em justificar a escolha do tema e em imprimir à narrativa o propósito de edificação moral interfere também no ritmo e na forma da narração. Se a intenção é tratar de um assunto considerado indecoroso, é preciso que isso seja feito de uma perspectiva analítica: a perspectiva daquele que relata para tentar compreender. Segundo Valéria de Marco, o que principalmente difere a confissão de Paulo, em

60 WERNECK, Maria Helena Vicente. Mestra: entre agulhas e amores: a leitora do século XIX na literatura de Machado e Alencar. Rio de Janeiro: Pontifícia Universidade Católica, 1985, p.37 e 26, respectivamente.

61 WERNECK, Maria Helena Vicente. Mestra: entre agulhas e amores: a leitora do século XIX na literatura de Machado e Alencar, op. cit, p.53. 
Lucíola, da de Armando, de A Dama das Camélias, é o fato de que a primeira nasce da necessidade de explicar uma "postura ética frente a um fenômeno social” e, portanto, pretende caracterizar-se "não como purgação do sofrimento, mas sim como processo de análise e conhecimento da mulher prostituída e de suas relações amorosas" ${ }^{\text {"62 }}$. Nesse sentido, a primeira medida tomada por Paulo é a opção pela palavra escrita que, afastando-se da espontaneidade da fala, proporciona uma narrativa mais pensada e refletida. Na introdução dirigida a G.M, o narrador afirma:

Receei também que a palavra viva, rápida e impressionável não pudesse, como a pena calma e refletida, perscrutar os mistérios que desejava desvendar-lhe, sem romper alguns fios da tênue gaza com que a fina educação envolve certas ideias, como envolve a moda em rendas e tecidos diáfanos os mais sedutores encantos de uma mulher. Vê-se tudo; mas furta-se aos olhos a indecente nudez. ${ }^{63}$

Trata-se, mais uma vez, de um dilema moral com que boa parte dos escritores de romances de cunho confessional, no século XIX, tinha de lidar. Como conciliar a liberdade e a exuberância de sentimentos inerentes a qualquer confissão espontânea, sem pecar contra as boas maneiras? Para Alencar, a linguagem serve de véu à ideia. $\mathrm{O}$ bom estilo é capaz de compensar o assunto tratado, por mais indecoroso que seja. Assim, ao iniciar o relato do episódio da orgia na casa de Sá - um dos mais eróticos da narrativa - Paulo chama a atenção para a linguagem, prevenindo G. M. - e evidentemente todos os demais leitores - de que "não achará imagem, nem palavra que revolte o bom gosto" "64. Também em um dos artigos escritos em defesa da peça "As Asas de um Anjo", Alencar desafia os censores a encontrarem "uma palavra que não possa ser pronunciada pelos lábios mais puros" e "escutada pelos ouvidos mais castos" . Nas palavras da personagem-leitora transcritas anteriormente, a linguagem aparece simbolizada pelo "véu da graça" e a "folha da figueira", símbolos do pudor, que servem para cobrir a narrativa, evitando a "indecente nudez".

62 DE MARCO, Valéria. O Império da Cortesã, op. cit, p.153.

63 Lucíola, 231.

64 Idem, p. 250.

65 ALENCAR, José de. Artigo sobre a peça “As Asas de um Anjo”. In: Obra Completa, vol IV, op. cit., p. 928,929 . 
A linguagem disciplina o ímpeto expressivo do relato, controla "as afoitezas da imaginação". Assim, tudo pode e deve ser dito (lembremo-nos que, para o romancista, a história imoral não admite reticências) desde que devidamente lapidado por uma linguagem casta e equilibrada que respeite as regras do decoro. Este aspecto da obra de Alencar confirma os argumentos desenvolvidos por Eduardo Vieira Martins em "A fonte Subterrânea: José de Alencar e a Retórica Oitocentista ${ }^{66,}$, de que haveria uma base clássica subjacente à literatura de Alencar cuja formação foi - assim como a dos demais autores do romantismo brasileiro - orientada pelos manuais de retórica e eloqüência que circulavam no Rio de Janeiro do século XIX.

No entanto, ainda assim, o impasse acima não estaria resolvido. Se o narrador está envolvido com os acontecimentos narrados, o leitor há de esperar um relato espontâneo, marcado pela emoção e pela naturalidade. $\mathrm{O}$ amaneiramento do estilo, a linguagem cuidada, o tom analítico que caracterizam a narrativa do início ao fim iriam, inevitavelmente, em oposição a essa expectativa. Para lidar com tal incongruência, Alencar utiliza-se de mais um elemento da estratégia discursiva: o desdobramento do narrador.

Como demonstram Valéria de Marco e Luis Filipe Ribeiro nos estudos já referidos, há, na estrutura da obra, dois Paulos: o Paulo-personagem, de vinte anos, ingênuo e inexperiente, que vive, à flor da pele, os acontecimentos; e o Paulo-narrador que confidencia a história seis anos depois, amadurecido pelas experiências vividas. Os episódios ocorridos com o Paulo-personagem servem de material de análise para o Paulo-narrador, e o intervalo de seis anos que separa o relato dos fatos supostamente ocorridos proporciona a filtragem necessária para construir a escrita pausada, composta por frases ponderadas.

Paulo-narrador difere de Paulo-personagem porque possui um distanciamento crítico diante dos fatos narrados. Em diversos momentos da narrativa, e principalmente nos momentos em que tenta explicar o comportamento da heroína, o narrador se dirige ao leitor com o propósito de reafirmar esse distanciamento:

66 C.f. MARTINS, Eduardo Vieira. A Fonte Subterrânea: José de Alencar e a Retórica Oitocentista". São Paulo: Edusp, 2005. 
Se naquela ocasião me viesse a ideia de estudar, como faço hoje à luz das minhas recordações, o caráter de Lúcia, desanimaria por certo à primeira tentativa. Felizmente era ator neste drama e guardei, como uma urna de cristal guarda por muito tempo o perfume de essência já evaporada, as primeiras impressões que eu então sentia.

Compreendo hoje as rápidas transições que se operavam nessa mulher; mas naquela ocasião, como podia adivinhar a causa ignota que transfigurava de repente a cortesã depravada na menina ingênua, ou na amante apaixonada." 67

O "eu" mais jovem de Paulo, "ator do drama" apresenta-se perplexo diante da heroína por não compreendê-la; já o "eu" mais velho, que narra a história, se não a compreende totalmente, ao menos é capaz de perceber, como mostra Luis Filipe, a "motivação ética"68 que jaz oculta por trás de suas atitudes tão contraditórias. Paulotestemunha vive, Paulo-narrador analisa a experiência vivida e oferece à leitora o perfil de mulher.

É bem verdade que, em diversos momentos, para resgatar o frescor dos acontecimentos, o narrador sacrifica esse distanciamento crítico, ao dar lugar ao Paulopersonagem. É o que ocorre, no exemplo dado por Regina Pontieri, quando Paulo, em um dos primeiros encontros com Lúcia afirma: "tinha apenas sede de prazer, fazia dessa

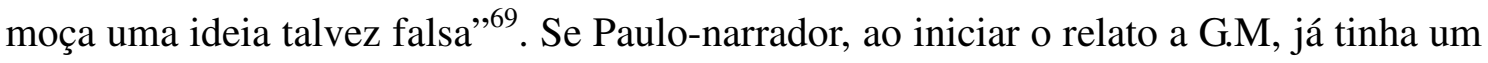
juízo formado a respeito da heroína, como poderia dizer que a ideia que fazia dela fosse talvez falsa ${ }^{70} \mathrm{~A}$ justificativa para a incoerência é dada pelo próprio narrador que afirma relatar os fatos "como se escrevesse no dia em que eles se sucederam, [...] ignorando o futuro",71.

O que parece claro nesse sentido é que Alencar está dividido entre duas ambições aparentemente antagônicas: por um lado, o desejo de imprimir à narrativa um caráter verossímil e espontâneo com o intuito de satisfazer um público ávido pelas revelações intimistas que configuram a "escrita do coração"; por outro lado, a

67 Lucíola, p. 262 e 265, respectivamente.

68 Cf. RIBEIRO, Luis Filipe. Mulheres de Papel, op. cit.

69 Lucíola, p. 237.

70 A questão é colocada por Regina Pontieri no trabalho já mencionado.

71 Lucíola, p. 243. 
necessidade de disciplinar o relato, e apresentar a narrativa de um ponto de vista analítico e reflexivo, com o objetivo de atribuir um propósito didático-moralizante a uma obra especialmente dedicada às mulheres. A intenção é deixar a obra atraente o bastante para que se torne popular, vendável; e, ao mesmo tempo, suficientemente edificante para que possa servir como peça de instrução. Tal contradição é bastante trabalhada por Peter Gay, que analisa o dilema dos romances introspectivos da era vitoriana:

quando diziam pouco eram enfadonhos, e provavelmente de vendas limitadas; quando diziam muito, pecavam contra as boas maneiras, embora fossem de certa forma irresistíveis. Expor o coração parecia uma atividade ao mesmo tempo recomendável e perigosa ${ }^{72}$.

Até aqui, buscamos demonstrar que a armação ficcional da autoria de Lucíola, faz parte de uma estratégia discursiva bastante elaborada que tem origem na relação do autor com os leitores. Preocupado em preservar a sua imagem de homem público e de escritor respeitador dos códigos sociais, e ciente de que sua obra seria lida também por mulheres - público considerado despreparado para a literatura séria - Alencar toma diversas precauções para que a narrativa seja bem recebida e adequadamente interpretada. Dentre estas preocupações, a mais importante - e a mais refinada - é a criação de uma personagem que funciona como uma representação de uma "leitora ideal", aquela em que a obra procura a verdadeira ressonância. Caracterizada como uma mulher madura, sensível e crítica, G. M. funciona como uma espécie de modelo que deve ser seguido por toda a mulher que lê. Ao mesmo tempo, o autor, escondido por trás da figura do narrador, guia os passos da destinatária, assim como, evidentemente, de todos os demais leitores, rumo à interpretação "correta" do romance. É assim que, por trás da relação narrador-destinatária, inteiramente fictícia, estabelece-se a relação autorleitores: esta real, e inserida no propósito didático-moralizante que Alencar, como muitos de seus contemporâneos, assume para si, como parte de um projeto literário e

72 GAY, Peter. O Coração Desvelado. São Paulo: Cia das Letras, 1999, p. 130. 
político. No que tange à protagonista da obra, caberá pensar, daqui em diante, de que maneira a construção da personagem reflete esse propósito que se desdobra na antítese vício/virtude, e de que maneira há, ao mesmo tempo, o esforço de Alencar em fugir de tal dicotomia, buscando alcançar uma maior complexidade psicológica. 


\section{O Duplo.}

"Esta beleza universal que a Antiguidade derramava solenemente sobre tudo não deixava de ser monótona, a mesma impressão, sempre repetida, pode fatigar com o tempo. $\mathrm{O}$ sublime sobre o sublime dificilmente produz um contraste, e tem-se a necessidade de descansar de tudo, até do belo. Parece ao contrário, que o grotesco é um tempo de parada, um termo de comparação, um ponto de partida, de onde nos elevamos para o belo com uma percepção mais fresca e mais excitada. A salamandra faz sobressair a ondina; o gnomo embeleza o silfo".

(Vitor Hugo, Do Grotesco e do Sublime) 


\subsection{O Arsenal romântico}

$\mathrm{Na}$ tentativa de buscar uma definição para o romantismo que contemplasse as diversas correntes que se desenvolveram no ocidente desde meados do século XVIII até a contemporaneidade, Michael Löwy e Robert Sayre ${ }^{73}$, encontraram um elemento unificador do movimento na quase totalidade de suas manifestações pelos principais centros europeus (Alemanha, Inglaterra e França): a oposição à modernidade capitalista-industrial. Diante do mundo burguês marcado pela racionalidade instrumental, pela economia de mercado, pelo espírito de cálculo, pela reificação das relações humanas, os românticos buscaram muitas vezes evadir-se por meio do reino transcendente da vida mística e da religião. Dentre as estratégias utilizadas pelas diversas correntes românticas na busca pelo reencantamento do mundo, o recurso ao mito teve um papel central. Tratava-se, segundo Löwy e Sayre, da criação de uma "nova mitologia" como a descrita por $\mathrm{Schlegel}^{74}$, fundamentada no idealismo e que, por meio de um arsenal inesgotável de símbolos, alegorias, anjos, ninfas, deuses e demônios, pudesse alimentar a imaginação poética do artista.

Alencar, seja por vocação ou por força da estética, foi um escritor imaginativo por excelência. Em todos os seus romances - entendidos, a bem lembrar, como "poemas da vida real" - o autor utiliza uma linguagem que transborda em metáforas, comparações, analogias que remetem muito mais à fantasia do que à descrição da vida cotidiana. Suas personagens, indígenas ou não, são carregadas de uma áurea de idealização que se traduz em rasgos de heroísmo, força e coragem descomunais, fidelidade inabalável, abnegação, caridade, constância.

É, sobretudo, neste aspecto de seu estilo em que se fundamentam os ataques sofridos pelo autor desde a época em que suas obras foram escritas. Mesmo a parcela da crítica favorável ao romancista foi quase unânime em considerar Alencar um escritor de

73 C.f. LÖWY, Michael e SAYRE, Robert. Revolta e Melancolia, o Romantismo da Contramão da Modernidade. Petrópolis, RJ: Vozes, 1995.

$74 \mathrm{O}$ argumento da necessidade de criação de uma mitologia poética que pudesse servir para os modernos como a mitologia clássica serviu para os antigos é desenvolvido por Schlegel em sua Conversa sobre Poesia. SCHLEGEL, Friedrich. "Discurso sobre a mitologia". In: Conversa sobre Poesia e outros fragmentos. São Paulo: Iluminuras, 1994. 
gabinete $^{75}$ a quem faltaria o senso de observação e análise necessário para reproduzir fielmente a realidade histórica ou o cotidiano que o cerca. "Um idealista da gema", escreveu José Veríssimo ${ }^{76}$, "levou a verdade aos exageros da imaginação" afirmou Gustavo Barroso ${ }^{77}$, escritor "do superlativo" cuja força "só se satisfaz na ênfase", opinou Olívio Montenegro ${ }^{78}$. Isso, sem falar em Joaquim Nabuco e Franklin Távora que, entre ofensas e ridicularizações, condenaram-lhe a obra quase toda nas polêmicas já citadas.

Diante dos ataques sofridos pelos contemporâneos, Alencar, como já mencionado, saiu em defesa de sua obra por meio de prefácios cartas e artigos publicados na imprensa. Neles, o autor algumas vezes contestou tais acusações explicitando suas fontes e preocupando-se em apresentar suas obras como documentos coerentes com realidade extratextual; outras vezes assumiu a idealização enfatizando o elemento fantasioso como o ponto alto e traço inevitável da obra de arte. Em um dos folhetins publicados no Diário do Rio, ao defender a cantora Emy La Grua, cuja interpretação de "Norma" vinha sendo criticada por supostas "exagerações", o romancista afirma:

Desde o momento em que o homem, nos vôos de sua inteligência se eleva acima das circunstâncias ordinárias da vida, desde que o seu pensamento se lança no espaço, possuído desse desejo ardente, dessa inspiração insaciável de atingir o sublime, não é possível marcar-lhe um dique, um ponto que lhe sirva de marco.

Ide dizer ao poeta que não deixe correr sua imaginação pelos espaços infinitos da fantasia, - ide dizer ao pintor que force o seu pincel quando corre sobre a tela, e eles vos responderão que o pensamento que os anima neste instante escraviza e esmaga a sua vontade; que a alma e o corpo cedem à força da inspiração que os arrebata neste momento. ${ }^{79}$

Alencar, como os artistas que defende, foi um escritor que se deixou arrebatar

75 A expressão foi usada por Franklin Távora em polêmica com Alencar, mas boa parte da crítica concorda com o argumento da falta de senso de observação e análise. Ver: TÁVORA, Franklin. Cartas a Cincinnato; estudos críticos de Semprônio. Pernambuco. J.W. De Medeiros, 1872.

76 VERÍSSIMO, José. "José de Alencar". In: José de Alencar, Obra Completa, vol III. Rio de Janeiro: Aguilar, 1958.

77 BARROSO, Gustavo. Discurso publicado em: Revista da Academia Brasileira de Letras. Volume XXX. Edição em homenagem ao centenário do nascimento de José de Alencar. Rio de Janeiro: maio de 1929 , p. 29.

78 MONTENEGRO, Olívio. "José de Alencar". In: O Romance Brasileiro. Rio de Janeiro: José Olympio, 1953.

79 ALENCAR, José de. Ao Correr da Pena, op. cit, p. 240. 
pela imaginação. Adepto da "riqueza de imagens" e do "luxo da fantasia", compreendia o conceito de verossimilhança, explica Eduardo Vieira Martins, muito mais como "coerência interna, adequação ao opinável, a às regras dos diferentes gêneros," ${ }^{80}$ do que como uma reprodução exata do realidade externa. Assim, o escritor, mesmo quando pisava no chão do realismo, preferia dar às personagens e às paisagens um colorido mais vivo, formas mais harmoniosas. No que tange às personagens femininas, a abordagem não poderia ser diferente e o mecanismo é explicado no mesmo folhetim:

A propósito das mulheres bonitas, faremos como o escultor que talha o mármore de uma estátua, não para ofendê-la, mas para modelar-lhe as formas elegantes e arredondar-lhe os mimosos contornos ${ }^{81}$

Repletas de "formas elegantes" e "contornos mimosos" cautelosamente modelados pela pena criativa do autor, as protagonistas das obras de Alencar são construídas, em certa medida, a partir do molde das heroínas do romance tradicional, já na época bastante difundido na Inglaterra por Richardson e Fielding, na França por Balzac, Dumas Filho, George Sand e, no Brasil, por Macedo. São extremamente belas, delicadas, angelicais e - ainda que por vez rompam com o habitual modelo de virtude e perfeição - mantem-se dentro do plano de idealização romântica, sendo possuidoras de moral inabalável. De modo geral, como aponta Cavalcanti Proença ${ }^{82}$ em seu divertido estudo sobre as donzelas alencarianas, "são todas parecidíssimas entre si, como irmãs que eram". O talhe esbelto, a languidez, os movimentos ondulantes, os opulentos cabelos, os pés macios e delicados compõem uma simbologia que se repete à exaustão e que obedece perfeitamente ao figurino romântico, inclusive - e sobretudo - quanto à castidade. Para Alencar, como aponta Proença, "a virgindade é um talismã”, o que faz com que o romancista abandone as suas raparigas "ao pé do altar" ${ }^{\prime}$.

É bem verdade, como também demonstra o crítico, que as musas alencarianas dos romances urbanos se locomovem num mundo autêntico em que trajes, aposentos e

80 MARTINS, Eduardo Vieira. A Fonte Subterrânea, op. cit., . 173.

81 ALENCAR, José de. Ao Correr da Pena, op. cit, p. 240.

82 PROENÇA, M. Cavalcanti. José de Alencar na Literatura Brasileira. Rio de Janeiro: Ed. Civilização Brasileira, 1966, p. 98.

83 Idem, p. 90. A exceção se dá com as personagens que permanecem donzelas mesmo depois do casamento e, evidentemente, com Lúcia que possui a "virgindade da alma". 
adereços são descritos com precisão e fidelidade documentais. Apesar disso, o estoque de imagens arquetípicas que cerca suas heroínas inevitavelmente afasta-as dos seres humanos convencionais. Basta atentar para a estatuária construída com ouro, mármore e bronze utilizada por Alencar para descrever as protagonistas de seus romances citadinos mais conhecidos: Lucíola, Diva e Senhora. Um conjunto erótico que entrelaça beleza, riqueza e recusa, como observa $S c h w a r{ }^{84}$, e que se adequa perfeitamente ao gosto do público leitor da época. É possível dizer que, assim como os heróis (Peri, Armando, João Canho, etc...) - talhados no molde dos cavaleiros medievais - esbanjam força, coragem e honradez sobrenaturais no Alencar "dos mocinhos", os arquétipos femininos imperam distribuindo graça, candura e encantos inigualáveis no Alencar especialmente dirigido às moças.

Em Lucíola, apesar da temática pouco convencional, o molde não é muito diferente. A superioridade do caráter da heroína, como já demonstramos, é defendida categoricamente, tanto pelo narrador, quanto por G. M., antes mesmo de que a narrativa se inicie. No entanto, Lúcia (assim como, em menor grau, Aurélia) difere-se das demais heroínas alencarianas por não se enquadrar no esteriótipo da mulher como pura passividade. É também a louca, a histérica, que encarna ao mesmo tempo o bem e o mal, o atraente e o repulsivo. Assim como o grotesco conceituado por Vitor Hugo é visto em um termo de comparação necessário para que se possa olhar para o belo com mais entusiasmo, o lado bacante da heroína realça, pelo contraste, sua alma angelical. De qualquer forma, pintada com as tintas fortes dos extremos, Lúcia, assim como suas “irmãs", também se distancia das mulheres reais. O trecho já citado da apresentação de G.M sugere os dois grandes arquétipos que servirão como modelo para a construção da personagem: Vênus e Maria, modelos de mulher "no Olímpio e no Paraíso terrestre":

Demais, se o livro cair nas mãos de alguma das poucas mulheres que lêem neste país, ela verá estátuas e quadros de mitologia, a que não falta nem o véu da graça, nem a folha da figueira, símbolos do pudor no Olímpio e no Paraíso terrestre (p. 229)

84 C.f. SCHWARZ, Roberto. “A Importação do Romance e suas Contradições em Alencar”. In: Ao Vencedor as Batatas. São Paulo: Duas Cidades/34, 2000, p. 54. 
A caracterização da heroína reunirá a pureza e a abnegação da Virgem, alternadas com os encantos sedutores das divindades da mitologia grega. Imagens do universo cristão e pagão se entrelaçarão para construir a personificação da teoria romântica do amor: cindido entre corpo e alma.

\subsection{Imagens arquetípicas}

Se o apelo ao mito, de modo geral, inerente à criação literária e especialmente à ficção romântica, ele pode aparecer em maior ou menor grau em cada obra dependendo do interesse do artista em ajustar os elementos estruturais da narrativa a um contexto de plausibilidade. Northrop Frye, em sua Crítica Arquetípica, estabelece categorias organizacionais que determinam cada um dos estágios deste ajuste dentro de uma obra, desde o mito isolado (não deslocado) que seria o extremo da invenção literária, até o naturalismo que representaria o ponto máximo de adequação do mito à experiência humana. Para Frye, a relação entre o mito e a representação da realidade ilumina muitos aspectos da ficção, especialmente da ficção mais popular que é "bastante realista para ser plausível em seus incidentes e, contudo, romanesca o bastante para ser uma boa história ${ }^{85 "}$.

Em seu agudíssimo artigo "As Imagens do Desejo" $" 86$, escrito a respeito de Senhora, João Luiz Lafetá utiliza-se da teoria do crítico norte-americano para demonstrar que a ficção de José de Alencar, apesar de basear-se em uma estrutura apoiada sobre forte substrato mítico (tendência romanesca), dirige-se a cada instante para a uma tentativa de adequar as imagens arquetípicas de seu enredo à experiência humana, tendo como base as regras de verossimilhança voltadas para o referente (tendência realista).

Com base na teoria de Frye e nos apontamentos de Lafetá, as próximas páginas deste trabalho procurarão analisar alguns elementos do vasto substrato mítico presente em Lucíola buscando compreender, sobretudo, de que maneira eles se refletem na

85 FRYE, Northrop “Crítica Arquetípica: a Teoria dos Mitos”. In: Anatomia da Crítica. São Paulo: Cultrix, 1957, p. 141.

86 LAFETÁ, João Luiz. “As Imagens do Desejo”. In: Senhora. São Paulo: Ática, 1990. 
protagonista da obra.

\subsection{O desejável e o indesejável.}

De acordo com Frye, os mitos são organizados segundo dois princípios: o Paraíso (espaço do desejo) e o Inferno (espaço do não-desejo). Essa forma de organização metafórica é denominada, respectivamente: apocalíptica e demoníaca. O mundo apocalíptico é a representação do lugar ideal, espaço de felicidade, graça e inocência, como convencionalizado no ocidente pelo Paraíso bíblico. A esfera demoníaca, por outro lado, liga-se intimamente a um Inferno existencial, "como o Inferno de Dante ou de Milton”. É, segundo Frye, a expressão de um espaço de angústia e sofrimento, "o mundo do pesadelo e do bode expiatório, do cativeiro da dor e da confusão" ${ }^{\sharp 7}$. De alguma maneira, esta é também a repetição de certo dualismo entre o bem e o mal, o pecado e a virtude, ou, mais ainda, a dualidade entre a sociedade tal como ela é, e tal como ela deveria ser, em termos utópicos. As imagens dos romances urbanos de Alencar, como demonstrou Lafetá, associam-se estreitamente a esses dois mundos.

\subsection{Afemme fatale.}

Em Lucíola, o mundo do divino demoníaco está deslocado para o universo humano de luxúria e depravação, associado à imagem da Lúcia bacante, de cor escarlate; mundo que atinge o máximo da sua representação na orgia da casa de Sá. Nesse contexto, a imagem da mulher aparece diretamente associada à figura de Eva, responsável pela queda da humanidade do Paraíso segundo a ideologia cristã. Assim, Lúcia, em sua existência corpórea sexuada, aparece ligada estreitamente ao pecado, à desordem e ao demônio. “_ Em lugar de Lúcia, diga-se Lúcifer" 88 - afirma o libertino Rochinha, em meio ao banquete erótico protagonizado pela cortesã.

87 FRYE, Northrop. Anatomia da Crítica, op. cit., p.148. 88 Lucíola, p. 253. 
A aproximação fonética que se transforma em provocação no dizer de Rochinha certamente não é aleatória. Lúcifer, como sabemos, é anjo portador da luz, o mais belo de todos os anjos que, revoltando-se contra Deus, cai do céu ao inferno transformandose no maior de todos os demônios. A paranomásia faz alusão à trajetória da personagem que, a essa altura da narrativa, o leitor - auxiliado pelo julgamento inicial de G.M. - já intuiu: Lúcia é a moça de alma cândida que, corrompida pelo meio, transforma-se em bacante infrene. Enquanto cortesã, é a encarnação máxima da "mulher-diabo", da mulher fatal que, portadora de uma sexualidade transgressora e incontrolável, semeia a ruína e a perdição entre os homens. Nas palavras de Paulo:

_ Era uma mulher; mas as formas palpitavam, a carne latejava sob os olhos que a devoravam; os lábios comiam de beijos a vítima que eles provocavam; e entre a cútis transparente corria o sangue, que se precipitava do coração espanando em cascatas! $!^{89}$

O esteriótipo da mulher fatal que Alencar apresenta em Lucíola remonta às Harpias e Górgonas da Grécia antiga e às Fúrias romanas. Encarna também, como mencionado, a poderosa Vênus e a Eva bíblica. Encontra correspondência ainda em uma tradição de mulheres fatais da história universal: Frinéia, Espásia, Salomé, Cleópatra, a Lilith da mitologia grega, e em uma série de cortesãs da literatura francesa oitocentista, como Margarida Gautier, a Dama das Camélias de Dumas Filho - (fonte explicitada pelo próprio autor em um jogo intertextual que permite com que Lúcia, lendo a obra, compare-se a Margarida) - ; a Manon Lescaut, de Abade Prévost (modelo da heroína de Dumas); a Marion Delorme de Victor Hugo e a Marco de Barrière - estas últimas também mencionadas por Alencar como modelos para a Carolina de "As Asas de um Anjo" ${ }^{90}$. Poderíamos incluir nesta lista Esther Van Gobsek, de Esplendor $e$ Miséria das Cortesãs de Balzac e, afastando-nos da França e retornando um pouco até o século XVIII por sugestão de Valéria de Marco, a Moll Flanders de Defoe. Lúcia bacante é, portanto, um “tipo", um arquétipo, um "clichê" literário, uma imagem que

89 Lucíola, p. 256.

90 As três cortesãs citadas foram mencionadas no artigo escrito por Alencar a respeito da peça "As Asas de um Anjo". In: José de Alencar: Obra Completa, vol. IV., op. cit., p. 925 e 928. As semelhanças e dessemelhanças entre Lúcia, Margarida e outras duas cortesãs da literatura da época: Manon Lescault, de Prévost, e Moll Flanders, de Defoe, foram discutidas por Valéria de Marco no estudo já referido. DE MARCO, Valéria. O Império da Cortesã, op. cit. 
vinha se repetindo com certa frequência e que já estava bastante convencionalizada no momento em que a obra foi escrita.

Mario Praz, em A Carne, a Morte e o Diabo na Literatura Romântica, explica que a figura da mulher fatal, apesar de comum no mito e na literatura desde a antiguidade clássica, só na segunda metade do século XIX passa a aparecer com uma frequência obsessiva na literatura ocidental, tornando-se um "tipo". Segundo Praz, na primeira metade do século predominava o modelo do herói byroniano, jovem e belo, cujo poder de atração dominava e destruía a mulher que por ele se apaixonasse. Já na segunda metade, os modelos se invertem e a mulher é que passa a assumir o papel de mutiladora. Assim, para Praz "o macho, primeiramente tendendo ao sadismo, inclina-se ao masoquismo no final do século" 91 ". Os "perfis de mulher" de Alencar situam-se exatamente dentro do esteriótipo invertido mencionado por Praz. Neles, os pares românticos masculinos (Paulo, Augusto e Fernando) são inferiores às suas amadas tanto na exuberância física, quanto na condição financeira. São jovens um tanto quanto frágeis que se apresentam inseguros e perplexos diante das mulheres-esfinge, belas, ricas e sarcásticas, que se esforçam para decifrar sob o risco de serem devorados.

Em Lucíola, Paulo-personagem é, como os outros, um jovem sensível, inexperiente e pobre. Distancia-se de Paulo-narrador, como se viu no segundo capítulo, exatamente pela imaturidade e incapacidade de analisar criticamente os acontecimentos que vivencia. Recém-chegado de Pernambuco e, portanto, pouco familiarizado com os códigos sociais da Corte, o herói apresenta-se no início da narrativa, como uma presa fácil diante da cortesã rica, aparentemente lasciva e de beleza estonteante. As diferentes vozes da cidade contribuem para a imagem de mulher fatal que Paulo, apesar da resistência inicial, passa a enxergar na moça. Lúcia, na opinião de alguns de seus amigos, é uma mulher "caprichosa e excêntrica" que abandona seus amantes sem "o mínimo pretexto" e "não admite que ninguém adquira direitos sobre ela" ${ }^{92}$ As informações obtidas por Paulo, o comportamento enigmático e a exuberância do corpo desnudado da cortesã aumentam o fascínio e, ao mesmo tempo, o horror vivenciado

91 PRAZ, Mario. A Carne, a Morte e o Diabo na Literatura Romântica. Campinas, SP: Editora da Unicamp, 1996, p.192.

92 Lucíola, p. 246 e 245, respectivamente. 
pelo jovem rapaz. Acuado, diante da alteridade estranha e ameaçadora, Paulo deseja possuí-la, dominá-la e matá-la:

É verdade, tinha frenesi de matar essa mulher; porém matá-la devorando-lhe as carnes, sufocando-a nos meus braços, gozando-a uma última vez, deixando-a já cadáver e mutilada para que depois de mim ninguém mais a possuísse ${ }^{93}$.

Voltando-nos mais uma vez para a teoria de Frye devemos lembrar que, para o crítico, o mundo divino demoníaco é simbolizado pelos elementos grandiosos e ameaçadores da natureza, da maneira "como apareceriam em uma sociedade não desenvolvida tecnologicamente" ${ }^{94}$. Se partirmos do pressuposto de que Alencar desloca e personifica esse mundo na esfera da Lúcia bacante, é possível entender os motivos pelo quais os momentos em que a cortesã entra em ação serem quase sempre descritos por meio de analogias animalescas, violentas e destrutivas. No primeiro contato sexual entre Lúcia e Paulo, a cortesã "arqueava-se em ondulações felinas", "dobrava-se em si mesma como uma cobra", "despedaçava os frágeis laços que lhe prendiam as vestes" e, com os "dentes de pérola, talhava o cadarço de seda que lhe opunha obstáculos", "o seu olhar queimava", e ela "às vezes parecia querer estrangulá-lo em seus braços" ou "asfixiá-lo com seus beijos" (p. 242). Na orgia promovida por Sá, Lúcia mais uma vez "despedaça" o copo de cristal em uma contração muscular (p.252), depois "salta na mesa", enquanto "as longas tranças se enroscam como serpentes vivas" (p.257). Após o espetáculo, Paulo compara-a a uma "jumenta ciosa que se precipita pelo campo mordendo os cavalos para despertar-lhes o apetite" (p. 258), a uma "serpente que enlaçava a presa nas suas mil voltas triturando-lhe o corpo", e a uma vertigem que "arrebata-lhe a consciência da própria existência" (p. 261).

Vimos no primeiro capítulo deste trabalho, que o corpo feminino, por encarnar a fertilidade, era tido, desde as comunidades agrícolas mais primitivas, como um espaço habitado pelas mesmas forças ocultas e misteriosas que habitam a terra. A desconfiança masculina diante deste corpo estranho e desconhecido era responsável por um híbrido

93 Lucíola, p. 286.

94 FRYE, Northrop. Anatomia da Crítica, p.148. 
de veneração e terror que dominava tanto o discurso religioso quanto o científico no século XIX brasileiro. Já que na mulher reside toda a natureza estranha, ela deve ser controlada, como também o é a natureza. A analogia entre a figura feminina e os estados violentos da natureza é, aliás, uma constante em Alencar, basta atentarmo-nos para a caracterização da sedutora Catita cuja aparição é sempre associada aos abismos e às tempestades em $O$ Gaúcho; e para o surpreendente processo de zoomorfismo com a qual o autor funde Berta e uma serpente em Til.

Nas descrições da "mulher-diabo" alguns elementos de caracterização chamam a atenção pela frequência com que aparecem nas descrições. O primeiro deles é o olhar. Compreendido desde o Renascimento como a ponte para o desnudamento da alma, ele é marcado na bacante pelas chispas de "fulgor satânico" e lampejos demoníacos. O segundo são os cabelos negros, em desordem, escorrendo luxuriosamente pelos ombros, ou presos em longas tranças que "se enroscam como serpentes vivas". Michelle Perrot explica que os cabelos longos e soltos são tradicionalmente usados para simbolizar a sedução feminina porque remetem à lã e à pele dos animais e constroem, portanto, uma atmosfera de selvageria: "o pelo mal domesticado sugere a presença inquietante da natureza ${ }^{95, "}$ A figura da serpente, também extremamente convencionalizada no ocidente como o símbolo da sedução e do pecado, associada à vasta cabeleira, evoca a aterrorizante Medusa e reforça a analogia entre a mulher e a natureza primitiva.

De acordo com Frye, quando deslocado na área imitativa baixa, o mundo demoníaco adentra o campo da "analogia da experiência", e a idealização praticamente desaparece dando lugar ao comum e típico. Nessa esfera, o mito atinge o ponto máximo de adequação à experiência humana, buscando uma verossimilhança maior com o mundo real. Podemos dizer que, assim como em Senhora e em outros romances urbanos de Alencar, o mundo da experiência em Lucíola é governado pelo dinheiro (“emblema do demoníaco", segundo Lafetá). É o espaço do luxo, da extravagância, da ostentação, regido pela lógica da conveniência, pelas relações mercantilizadas, pela comercialização do corpo. Tal universo, Alencar representa por meio de uma galeria de

95 PERROT, Michelle. Minha História das Mulheres. São Paulo: Contexto, 2007, p. 51. 
tipos mais ou menos ridículos, imorais, libertinos: Sá, Cunha, Couto, Rochinha e as prostitutas mundanas (aquelas que, relegadas à esfera periférica da obra, não possuem a pureza d'alma de Lúcia).

No entanto, ainda que pertença à parte realista da obra, o episódio do banquete protagonizado pela cortesã - ponto alto do universo demoníaco, como mencionado - é carregado de um exotismo que, em última instância, projeta também um mundo fantasioso e idealizado no hemisfério dialeticamente oposto do hemisfério místico que tomará forma na segunda parte da narrativa: o mundo dionisíaco dos sentidos. Ao iniciar o relato, com a intenção de advertir G.M. (e os demais leitores) para o elevado nível de erotismo presente nas cenas que serão relatadas, Alencar preludia a narração com referências a trechos da literatura greco-romana:

Se a senhora não conhece as odes de Horácio e os Amores de Ovídio, se nunca leu a descrição da festa de Baco e não tem notícia dos mistérios de Adônis ou do rito afrodisíaco das virgens de Pafos, que em comemoração do nascimento da deusa iam certos dias do ano banhar-se na espuma do mar e oferecer as primícias do seu amor a quem mais cedo as cobiçava; se ignora tudo isso, rasgue estas folhas. ${ }^{96}$

Em seguida, ao descrever nos pormenores a decoração da sala de Sá, o romancista transfere a narrativa para um território estrangeiro, distante, recriando o ambiente das festas orgíacas da antiguidade. As paredes cobertas por um veludo de "sóbrio escarlate" sobre as quais uma profusão de espelhos multiplicavam os objetos e "projetavam as imagens em todos os sentidos e por mil faces", as duas séries de quadros representando os mistérios de Lesbos, os aparadores de mármore e os bufetes cobertos de iguarias e vinho, a orla aveludada que cercava a mesa convidando o homem "a espojar-se [...] como um jovem poldro", as cadeiras medidas para dois corpos e separadas por cortinas de flores que proporcionavam "ao mesmo tempo a solidão e a convivência"97 . Todos esses elementos corroboram para a construção de um lugar onde os impulsos podem fluir livremente. As palavras usadas pelo anfitrião ao anunciar as etapas do evento explicitam tal concepção:

96 Lucíola, p. 250.

97 Idem, p. 250 e 251 , respectivamente. 
Procedamos em regra. Às duas horas portanto para-se a pêndula. Abolição completa da razão, do tempo, da luz; e inauguração solene do reinado das trevas e da loucura. ${ }^{98}$

Nesse sentido, é importante lembrar do isolamento da casa de Sá, situada em uma chácara afastada da cidade, cercada por altas árvores que impediriam que o os ecos da festa perturbassem "o plácido sono dos vizinhos" ou "os castos pensamentos de alguma virgem." $"$. Aliás, como observou agudamente Luis Filipe Ribeiro, não nos é oferecida qualquer informação sobre a localização da casa em que o banquete ocorre (nem da casa de Lúcia) ${ }^{100}$. Trata-se de uma espécie de não-lugar, espaço da evasão, do sonho e do pecado consentido. Um território desconhecido, escuro, estrangeiro e caótico que se opõe ao mundo calmo, conhecido e iluminado que se materializará na segunda metade da narrativa. Uma oposição que parece reproduzir o embate que, segundo o historiador Mircea Eliade, caracterizaria a maior parte das sociedades tradicionais: a oposição entre o entre o mundo habitado e organizado (o Cosmos) e o mundo estranho, desorganizado, e "povoado de espectros, demônios e 'estranhos"”,101 (o Caos).

Mario Praz, no estudo mencionado anteriormente, aborda as aproximações entre o artista místico e o exótico. Segundo Praz, ambos projetam um mundo ideal, fantasioso onde os desejos podem ser realizados em sua plenitude, sem interdição:

Entre o místico que nega o mundo dos sentidos e o exotista que o afirma, entre o místico que esvazia de conteúdo material o seu universo e o exotista que se investe da vibração de seus sentidos e materializa as épocas remotas e os países distantes, há uma semelhança de intenções; ambos transferem a um mundo ideal, de sonho, a realização de seus desejos. ${ }^{102}$

Se concluirmos, a partir dos apontamentos de Praz, que Alencar constrói, tanto não espaço apocalíptico quanto no demoníaco, um espaço de desejo, seja ele

98 Lucíola, p. 252.

99 Idem, p. 249.

100 RIBEIRO, Luis Filipe. Mulheres de Papel, op. cit., p. 382.

101 ELIADE, Mircea. O Sagrado e o Profano. São Paulo: Martins Fontes, 2008, p. 33.

102 PRAZ, Mario. A Carne, A Morte e o Diabo na Literatura Romântica. op. cit, p. 189. 
transcendental (no plano místico) ou carnal (no plano exótico), é possível também concluir que a protagonista da obra, arquétipo dos dois mundos, é idealizada de modo a apresentar-se enquanto objeto do desejo nas duas esferas. Mulher-anjo e mulherdiabo, ela é sempre construída de modo a contemplar as expectativas alheias. O ponto máximo da representação de Lúcia enquanto objeto de desejo do narrador (e, portanto, do autor) no mundo demoníaco é o momento em que a cortesã, a pedido dos convidados, coloca-se à mesa imitando as figuras presentes nos quadros eróticos de Sá.

Lúcia saltava sobre a mesa. Arrancando uma palma de um dos jarros de flores, trançou-a nos cabelos, coroando-se de verbena, como as virgens gregas $[\ldots]$, arqueou os braços e começou a imitar uma a uma as lascivas pinturas; [...] Deviam ser sublimes de beleza sensualidade esses quadros vivos, que sucediam rápidos; porque até as mulheres aplaudiam com entusiasmo e frenesi. ${ }^{103}$

Assim como a Amália de Encarnação, que transforma seu próprio corpo em réplica da amada morta do homem por quem havia se apaixonado ${ }^{104}$, Lúcia petrifica-se para atender as expectativas do grupo que a contempla. Transformada em estátua viva, em objeto exótico e erótico do festim báquico que protagoniza, a heroína abre mão de sua identidade e elimina, ainda que por alguns momentos, a ambiguidade que resistia latente no olhar de Paulo. Torna-se só corpo. O mesmo corpo que, nas palavras da cortesã, "seria pasto dos vermes, como foi pasto dos homens",

Ao colocar o corpo feminino desnudo sob a mesa junto aos demais elementos que compõem o banquete, Alencar explicita mais um componente ideológico bastante presente no imaginário romântico: a associação entre a mulher e a gastronomia. Tal associação já havia sido exposta alguns capítulos antes quando Paulo, junto a seu amigo Cunha, apreciava as moças que compunham a plateia do teatro:

Esperando que levantasse o pano, corríamos ambos com o binóculo as ordens de camarotes, que se começavam a encher. É um regalo

103 Lucíola, p. 257.

104 Ruth Silviano Brandão analisa a questão da representação literária da mulher enquanto objeto de amor narcísico do narrador no romance Encarnação, de José de Alencar. BRANDÃO, Ruth Salviano. Mulher ao Pé da Letra: a personagem feminina na literatura. Belo Horizonte: Editora UFMG, 2006.

105 Lucíola, p. 252. 
semelhante ao do gastrônomo, que antes de sentar-se a mesa belisca as iguarias que vão se ostentando aos olhos gulosos. A comparação me agrada; porque realmente nunca sentia essa gula no olhar que devora com uma fome canina, como quando contemplava uma multidão de mulheres bonitas. ${ }^{106}$

O canibalismo, de acordo com Frye, se configura, na esfera demoníaca, como uma paródia do símbolo eucarístico do mundo apocalíptico. A alimentação que se dá no ritual eucarístico de maneira metafórica: a absorção da "carne" e do "sangue" de Cristo como forma de união espiritual e cósmica, aparece na esfera demoníaca de forma material e concreta, em rituais de sacrifício e mutilação. ${ }^{107}$ Lúcia, enquanto representação da figura da mulher castradora, de sexualidade descontrolada, desperta ainda mais, em Paulo e nos demais, um desejo sádico de dominação, mas uma dominação compensatória que se fundamenta, segundo o estudo de Maria Cecília Queirós de Moraes Pinto, no medo da mulher: "Se o homem come, devora, mata, ou tem ímpetos de fazê-lo", afirma Maria Cecília, "é porque, por outro lado, persiste em seu imaginário a figura da mulher castradora que inibe e mutila a sua sexualidade"108.

Paulo, como vimos, fantasia possuir Lúcia "devorando-lhe as carnes", consumindo-a, como o faz, simbolicamente, ao sorver "até a última gota"109 o copo cheio do licor no qual a bacante havia mergulhado o dedo ferido para estancar-lhe o sangue. Devorando-lhe as carnes, bebendo-lhe o sangue, Paulo busca proteger a si mesmo e a sua própria sexualidade.

\subsection{A femme fragile}

Para Frye, o avesso dialético da esfera demoníaca é, como mencionado, a esfera apocalíptica (espaço do desejo). Ligado diretamente ao céu religioso, ao Paraíso

\footnotetext{
106 Idem, p. 243.

107 FRYE, Northrop. Anatomia da Crítica, op. cit., p. 149, 150.

108 PINTO, Maria Cecília Queiroz de Moraes. José de Alencar e a França: perfis, op. cit., p. 135. À guisa de hipótese, talvez seja possível dizer que o medo da mulher, neste caso, reflita também o medo do amor, entendido como relação sexual, que Mario de Andrade aponta nos poetas românticos brasileiros, em especial, Álvares de Azevedo. ANDRADE, Mario. "Amor e Medo". In: Aspectos da Literatura Brasileira. Belo Horizonte: Itatiaia, sd.

109 Lucíola, p. 252.
} 
bíblico. É esse o campo da virtude que, segundo o crítico, "une-se estreitíssimamente à infância e ao estado de inocência - o da castidade (..) que na estrutura das imagens compreende em regra a virgindade" ${ }^{" 110}$. Em Lucíola, esse é o universo é construído por Alencar especialmente na segunda parte da narrativa, um ambiente claro e ensolarado, em que a cor que predomina é o branco, ao invés do escarlate, e a heroína aparece como "anjo", "menina", "flor" - denominações que excluem da mulher o elemento sexual. Há dois momentos da narrativa em que a heroína encarna o mundo da inocência: o primeiro é o episódio das Laranjeiras, quando Paulo, ainda ignorante do papel que Lúcia ocupava na sociedade, enxerga-a como "uma encantadora menina", de "alma pura e rosto mimoso"111. O segundo é o momento posterior ao processo de expiação, quando ela se transforma efetivamente em Maria da Glória.

As metáforas agregadas à heroína dentro desse campo modificam-se à medida que se intensifica o seu processo de "purificação" e "regeneração". Nos primeiros encontros com Paulo, o lado bacante da heroína se alterna com manifestações de pureza ligadas ao universo infantil. Ao receber de presente um adereço simples, a personagem é descrita em sua "ingênua alegria", entre "travessuras de criança" e "garridices de menina" (p. 264). Algum tempo depois, é descrita "como criança traquinas, que surpreende em flagrante o ralho paterno" (p. 264). É a atmosfera de ingenuidade e pureza que Alencar, seguindo os preceitos de Rousseau, busca atribuir à personagem, nos momentos em que a alma pura sobrepõe-se à personalidade bacante.

Em uma perspectiva rousseauniana, como sabemos, a valorização da infância está relacionada à ideia de uma pureza original que se perde à medida que o indivíduo vai sendo corrompido pela sociedade. Lúcia adquire ares de menina sempre que as distrações do cotidiano, e a relação, até certo ponto ambígua, que constrói com Paulo a fazem esquecer-se do papel que ocupa na Corte fluminense. É para esse universo de inocência que a heroína se projeta por um breve momento, ao ouvir narração da existência bucólica e do amor fraternal e puro de Paulo e Virgínia, personagens do livro homônimo de Bernardin de Saint-Pierre.

110 FRYE, Northrop. Anatomia da Crítica, op. cit., p. 152.

$111 \quad$ Lucíola, p. 257. 
Quando eu lia a descrição das suas cabanas e da infância dos amantes, Lúcia deixou pender a cabeça sobre o seio, cruzou as mãos nos joelhos dobrando o talhe [...]

De repente a voz desatou num suspiro:

_ Ah, meu tempo de menina! ${ }^{112}$

Percebendo-se incapaz de reviver os tempos de menina e de recuperar a inocência perdida, a heroína chora e interrompe a leitura da obra arrancando-a das mãos de Paulo. O episódio, narrado com certa displicência, traz um ponto de vista bastante claro e sugerido pela própria heroína: a mulher perdida, aquela que tem o corpo marcado pelo pecado, jamais voltará ao estado de pureza original, resta-lhe, portanto, o papel da pecadora arrependida em busca da salvação.

Assim, à medida que o processo de expiação se concretiza, Lúcia deixa de ser figurada como uma criança e passa a encarnar de fato Maria - a mater dolorosa. Seu comportamento é cada vez mais submisso e resignado. Nesses momentos, a personagem é figurada frequentemente ajoelhada aos pés de Paulo, obediente e resignada, "com os olhos baixos e submissa como uma escrava" ou "com o olhar humilde e a expressão suplicante" (p. 294). Seu semblante, antes marcado pelo "brilho nos olhos" e o "viço da pela suave", perde o esmalte fresco e, e adquire cada vez mais uma “morbidez lânguida" e "laivos melancólicos (323)”. É o heroísmo da abnegação.

Nesse sentido, um dos elementos usados por Alencar para marcar a transformação da heroína em mártir é a mudança ocorrida em suas vestes. Os roupões de seda e cambraia de cores suaves e alvos colarinhos que caracterizavam a menina de alma pura, e os luxuosos vestidos escarlates que caracterizavam a cortesã passam paulatinamente a dar lugar às roupas sóbrias, largas, de tecido escuro e sem ornamentos. "Vestido de merinó escuro", "mantelete de seda preta" e chapéu de palha, eram alguns dos elementos que compunham as vestimentas da heroína durante os passeios pelo campo. Em um desses passeios, Alencar nos oferece o figurino completo:

Lúcia trazia nessa manhã um trajo quase severo: vestido escuro, afogado e de mangas compridas, com pouca roda, simples colarinho e punhos de linho rebatidos: cabelos negligentemente enrolados e uma

112 Idem, p. 304. 
basta madeixa, sem ornato nenhum. Em vez dos pantufos aveludados que costumava usar em casa, [...] calçava uma botinha de merinó preto $^{113}$.

$\mathrm{O}$ vestido escuro e largo lembra as vestes religiosas. Tal qual os monges e as freiras, Lúcia cobre o corpo, escondendo-o, negando-o para garantir a salvação da alma. Assim, à medida que esconde o corpo, Lúcia passa paulatinamente a esquivar-se das investidas de Paulo até recusar completamente o contato sexual com o amado. As recusas, no entanto, acontecem em meio a um jogo complexo de afastamento e aproximação que será analisado no momento conveniente.

Por hora, interessa-nos lembrar apenas que a mudança nos trajes da heroína traz uma nova cor para narrativa: o preto. E, acompanhada pelas mudanças de casa e de mobília, ajuda a construir um ambiente de martírio e penitência mais condizente com a figura da mulher "perdida" em busca da salvação. No casebre simples para o qual se muda, inteiramente diferente da casa elegante que habitava anteriormente, o quarto de dormir, de "extrema simplicidade", lembra as celas religiosas dos conventos: uma cama de ferro, uma banquinha de cabeceira e um crucifixo de marfim diante do qual a heroína passa a rezar todas as noites. Ao ser questionada por Paulo a respeito da mudança brusca, Lúcia justifica-se por meio de um discurso que se fundamenta na negação ao luxo e na entrega divina: "quando entro aqui, sacudo no limiar da porta como os viajantes, a poeira do caminho; e Deus me recebe"114

Com todos esses elementos Alencar constrói gradativamente a imagem da mulher penitenciada, martirizada, que se afasta do mundo e renuncia à vida cotidiana para, por meio de uma trajetória de sacrifício e expiação, libertar a alma do pecado e entregá-la à salvação eterna. Entre os castigos que a heroína impõe a si mesma há, inclusive, o jejum, uma das formas mais tradicionais de penitência, recomendada constantemente pela igreja como instrumento de santificação. Em um dos passeios campestres que tomam lugar no cenário bucólico do bairro de Santa Teresa, o casal almoça “como os Pastores de Teócrito: frutas, pão e leite cru”, em outro, o narrador afirma que "Lúcia contentou-se com uma côdea de pão e um copo de leite que bebeu 
sentada sobre uma pedra."

Impondo-se uma rotina similar à de um convento, caracterizada pela reclusão, pela renúncia ao luxo e à vaidade, pela alimentação quase a pão e água, pela abstinência, as orações, a dedicação a Deus, Lúcia, como mencionamos, incorpora gradativamente a imagem da pecadora arrependida, abnegada e sofredora, posta no caminho da penitência para garantir a jornada ao céu. A transformação culmina com o momento em que, ao narrar a Paulo seu passado e esclarecer os motivos que a levaram a prostituição, Lúcia adquire um novo nome, uma nova identidade: Maria da Glória. O desdobramento da personagem, anunciado desde o início da narrativa por meios das nuances e oscilações, agora se realiza concretamente. O passado foi expurgado e, com ele, a personagem cortesã. A nova identidade marca o nascimento de uma nova heroína.

Dentro da "analogia da inocência" é interessante lembrar a simbologia da água como elemento purificador. Depois de uma noite em que Lúcia, a pedido de Paulo, retoma, ao menos socialmente, o lugar que ocupava como cortesã, um banho é suficiente para cobri-la novamente com o manto da virtude.

Lúcia demorou-se algum tempo. Quando apareceu, saía do banho fresca e viçosa. Trazia os cabelos ainda úmidos; e a pele rorejada de gotas d'água. Rica e inexaurível era a organização dessa moça, que depois de tão violento abalo parecia criar nova seiva e florescer com o primeiro raio de felicidade!

Fora o acaso ou uma doce inspiração, que arranjara o traje puro e simples que ela trazia? Tudo era branco e resplandecente como a sua fronte serena: por vestes cassas e rendas; por jóias somente pérolas. Nem uma fita, nem um aro dourado, manchava essa nítida e cândida imagem. ${ }^{116}$

Sabemos que o com as águas, desde os tempos mais remotos, e nas mais diversas religiões, remetem à ideia de regeneração e renascimento. De acordo com Mircea Eliade, "tanto no plano cosmológico quanto no plano antropológico, a imersão às Águas equivale não a uma extinção definitiva, mas a uma reintegração passageira do

115 Lucíola, p. 310 e 319, respectivamente.

116 Lucíola, p. 290. 
indistinto, seguida da criação de uma nova vida e de um homem novo"117. No imaginário cristão a água está presente, sobretudo, no ritual do batismo que proporcionaria a purificação e o retorno à inocência primitiva. Nesse episódio do romance a água limpa a heroína das imagens relacionadas ao universo da luxuria, levando embora a cortesã "quebrada de fadiga", deixando em seu lugar a virgem de fronte serena. A passagem do escarlate ao branco se dá de maneira tão clara e imediata que, ao leitor, fica nitidamente evidenciada a antítese entre os dois mundos.

Seguindo a sugestão de Lafetá, podemos considerar o mundo apocalíptico, na área imitativa elevada, o mundo simbolizado pelo amor romântico, "dois corpos reunidos no mesmo corpo". O amor idealizado, mítico, invencível, que em Lucíola, é responsável pelo isolamento do par amoroso na natureza e pela "regeneração" da cortesã. Se voltarmos para a construção da heroína, podemos perceber que Lúcia associa-se a imagens de pureza e abnegação sempre que está sozinha diante de Paulo. Por outro lado, as imagens da devassidão ligam-se à heroína sempre que ela se encontra em sociedade. A analogia desenvolvida pela personagem diante da água do tanque em que Paulo atira pedras parece traduzir essa ideia.

_ Naquele dia... não soube explicar-lhe... É isto! A lama deste tanque é meu corpo: enquanto a deixam no fundo e em repouso, a água está pura e límpida! ${ }^{118}$

O olhar provinciano de Paulo, cuja percepção ainda não havia se deformado, consegue ver na heroína a menina de alma pura e não a cortesã; os olhares da opinião pública, no entanto, insistem em colocá-la de volta em seu papel. A adaptação da personalidade da cortesã ao olhar do outro é um fator importante a se levar em consideração na construção da heroína e será analisado no próximo capítulo deste trabalho. No momento, convém apenas lembrar que o processo de expiação de Lúcia se dá, essencialmente por três fatores: o isolamento na natureza, que reflete a necessidade de se afastar dos códigos sociais e morais da coletividade; a negação do luxo, expressa,

117 ELIADE, Mircea. O Sagrado e o Profano - a essência das religiões. São Paulo: Martins Fontes, 2008, p. 110.

118 Lucíola, p. 311. 
como mencionamos, pela mudança de casa e de vestes; e, sobretudo, a negação do sexo. Dante Moreira Leite, analisando Lucíola à luz da psicanálise, atentou para o fato de que o corpo para os românticos é sempre um elemento perturbador, já que "o amor, como forma de pureza não pode ser contaminado pela sensualidade física"119. Assim, Alencar teria encontrado uma maneira de lidar com essa dicotomia colocando na mesma mulher a virgem pura e a cortesã: Maria é a alma, Lúcia é o corpo.

A divisão, no entanto, perfeitamente aceitável dentro do universo mítico romântico, é inconcebível no plano físico e a heroína morre. A morte heroica e libertadora é também uma constante no romantismo e expressa o desejo de união e fusão mística do par amoroso que não é possível em termos humanos. Alencar explicita tal desejo, por meio do discurso proferido por Lúcia em seus últimos momentos de vida:

_ Agora que o corpo já está morto e que a carne álgida não sente nem a dor nem o prazer, é a minha alma só que te beija, que se une à tua e se desprende parcela por parcela para se embeber em eu seio. (....) Recebe-me ... Paulo!... ${ }^{120}$

Podemos dizer que nesse romance de Alencar, mais do que eu nenhum outro, o espaço do desejo e do não-desejo estão delimitados e separados na estrutura da obra. $\mathrm{O}$ "mundo da experiência" governado pelo dinheiro, pelos códigos sociais, pelas relações humanas mercantilizadas é protagonizado por Lúcia e retratado, sobretudo, na primeira parte da obra. Na segunda parte, que se estende até o final do romance, entra em cena o "mundo da inocência", espaço da natureza e do amor romântico, protagonizado por Maria da Glória. Assim, podemos notar na própria estrutura da obra uma cisão: se na primeira metade da narrativa há uma preocupação maior com um retrato da sociedade imperial do Rio de Janeiro, demonstrando uma tendência "realista" (e há que se lembrar que, as descrições da Lúcia bacante beiram, inclusive, o naturalismo); na segunda parte, há uma tendência maior para a idealização, pendendo quase que exclusivamente para o

119 LEITE, Dante Moreira. O Amor Romântico e outros Temas. São Paulo: Unesp/ Ucitec, 1987, p. 56.

120 Luciola, p. 317. 
romanesco. Essa divisão quase estanque dos dois mundos é também uma maneira de contrapor o espaço público ao privado e talvez explique a perda de dramaticidade e dinamismo da obra na segunda metade. No entanto, convém lembrar novamente que Alencar, fiel aos pressupostos românticos, demonstra acentuada preferência pelo metafórico (e romanesco) na obra como um todo.

Até aqui, o trabalho se propôs a apontar alguns elementos do vasto conteúdo arquetípico desta obra de José de Alencar e mostrar como o substrato mítico ligado aos mundos apocalíptico e demoníaco, deslocado para a experiência humana, se faz notar não apenas na estrutura da narrativa, como na própria construção da heroína: ser bifronte: ao mesmo tempo virgem e bacante. As páginas que se seguem procurarão abordar com mais profundidade o comportamento oscilatório de Lúcia para entender em que medida a construção das protagonistas de Alencar nos "perfis de mulher" demonstra, ao mesmo tempo, uma ruptura com o psicologismo tipificado próprio das personagens da narrativa romanesca, refletindo uma influência do romantismo de tendência realista. 


\section{Que Diabo de Gênio o dessa Rapariga? ${ }^{121}$}

"E assim é tudo nela; de contraste em contraste, mudando a cada instante, sua existência tem a constância da volubilidade. Na vaga flutuação dessa alma, como no seio da onda, se desenha o mundo que a cerca; a sombra apaga a luz, uma forma desvanece a outra; ela é a imagem de tudo, menos de si própria."

(José de Alencar, Til)

"Como então Lucíola é a mesma coisa que a Dame aux Camélias, se nesta não se encontra a questão fisiológica, ainda mais quando naquela a questão fisiológica é todo o romance?"

(José de Alencar, A Polêmica Alencar- Nabuco)

121 ARARIPE JUNIOR. "José de Alencar: perfil Literário". In: Obra Crítica de Araripe Junior. Rio de Janeiro: Ministério de Educação e Cultura. Casa de Rui Barbosa, 1958, p.187. 


\subsection{A esfinge.}

Caprichosa, excêntrica, desdobrável, Lúcia é uma representante do gênero das "mulheres-esfinge" criadas por Alencar. Criaturas misteriosas, mulheres "cujo gênero é o ser e o não ser ${ }^{122,}$, portadoras de uma essência enigmática que surpreende e provoca. Assim como nos demais "perfis" do autor, a caracterização de Lúcia - como procurouse demonstrar no capítulo anterior - assume um caráter paradoxal. A cortesã experiente que coleciona amantes é apresentada pela primeira vez ao leitor em uma festa religiosa trajando vestido sóbrio e com ar de "ingênua castidade". A antítese já está colocada. Mas é, sobretudo, nos primeiros encontros com Paulo que, por meio de uma série de diálogos carregados de tensão dramática, Alencar nos apresenta, de forma mais subjetiva, as ambiguidades de comportamento da personagem. A bacante de "olhar límpido e sereno" e "gesto quase infantil", "ora levava a impudência até o cinismo, ora esquecia-se do seu papel no simples e modesto recato de uma senhora ${ }^{123}$ ". À medida que a narrativa evolui Alencar acentua cada vez mais o caráter excêntrico e contraditório da personagem que passa a irritar e confundir Paulo em uma oscilação constante entre polos opostos: avidez e frigidez.

Incompreensível mulher!

À noite a vira bacante infrene, calcando aos pés lascivos o pudor e a dignidade, ostentar o vício na maior torpeza do cinismo, com toda a hediondez de sua beleza. A manhã a encontrava tímida menina, amante casta e ingênua, bebendo num olhar a felicidade que dera, e suplicando o perdão da felicidade que recebera. ${ }^{124}$

De manhã pura, de noite bacante, e na manhã seguinte pura novamente, a complexidade psicológica de Lúcia contrasta com a simplicidade da estrutura do romance brasileiro nesse primeiro momento e leva boa parte da crítica do século XIX a considerá-la ilógica ou inverossímil. "Lucíola e Diva não passam de uns monstrengos

122 ALENCAR, José de. Til. In: Obra Completa, vol. III. Rio de Janeiro: Aguilar, 1959, p. 828.

123 Lucíola, p.243.

124 Ibidem, p.262. 
morais ${ }^{125 "}$ afirmou o Conselheiro Lafaiete, conceito reiterado por Araripe Junior que chega a enxergar na primeira um caso de ninfomania:

Lúcia é feroz, idiossincrática, a prostituição nessa mulher é um desespero inexplicável, que a todo instante contrasta com sua alma poética do tipo ideal, que o autor tem diante dos olhos. Lúcia é quase ninfomaníaca. [...] $\mathrm{O}$ autor de Iracema, dando corda ao seu gênio fantasioso, apresenta um retrato esdrúxulo, senão uma dessas extravagâncias à Edgar Poe, em que a razão cambaleia de braço dado com a imaginação do nevrótico. A dualidade de Lúcia, pois, no campo dos atos conscientes da alma normal é inadmissível. ${ }^{126}$

Joaquim Nabuco, em polêmica com Alencar, faz coro com os demais críticos:

Até que ponto pode ser uma cortesã desenfreada e uma virgem inocente; como o vício e a virtude em seus extremos podem reunir-se em um mesmo coração, como pode subsistir a identidade da consciência no meio das contradições, é o que o Sr. J. de Alencar não estudou em Lucíola, ao apresentar-nos esse tipo, que ele quis fazer desprezível e adorável! ${ }^{127}$

Já no início do século XX, Artur Mota, utiliza-se dos mesmos argumentos para questionar a dualidade da personagem:

É um tipo de mulher inconsequente e abstrusa, verdadeiro fruto da imaginação do autor. A psicologia de Lúcia é falsa, pois não se compreende a dualidade desse caráter incongruente.

A amante de Paulo assume atitudes extremas de bacante devassa, extremamente impudica, e de amorosa donzela; percorre a gama completa da dissipação à avareza; varia de sentimentos e atitudes como um camaleão muda de cor; é um misto de Messalina e Julieta, de Sapho e Virginia, de Nana e Carlota ou Carolina. ${ }^{128}$

A dualidade de Lúcia, por um lado, já foi discutida no capítulo anterior: Alencar incorpora na mesma personagem arquétipos relacionados a dois mundos antagônicos, o

125 ARARIPE JUNIOR. "José de Alencar: perfil literário". Obra Crítica de Araripe Jr., op. cit, p. 184.

126 Idem, p. 184.

127 COUTINHO, Afrânio (org). A Polêmica Alencar-Nabuco. Rio de Janeiro: Ed. Tempo Brasileiro, 1965, p. 135.

128 MOTA, Artur. José de Alencar (o escritor e o político) - sua vida e sua obra. Rio de Janeiro, F. Briguet, 1921, p. 83. 
do desejo e o do não desejo, numa tentativa de separar corpo e alma, como a concepção romântica da mulher exigia. No entanto, o que parece incomodar mais a crítica da época é o fato das oscilações acontecerem sem transições graduadas e sem uma justificativa que considerem plausível. Podemos dizer, portanto, que o que choca nas personagens Lúcia e Emília não é exatamente a dualidade, e sim a excentricidade, a volubilidade, ou para usar uma expressão de Nabuco "o histerismo dos movimentos ${ }^{129,}$.

Convém notar que o terceiro perfil de mulher de Alencar, Senhora, também traz uma heroína ambígua, contra a qual a críticos já citados (com exceção de Nabuco) não se colocam. A diferença na recepção é compreensível: enquanto o conflito de Aurélia se fundamenta no outro, ou, mais precisamente, no desejo de reformar o objeto amado para que este venha a merecê-la; o de Lúcia - assim como o de Emília e de Carolina (da peça teatral) - se origina na psicologia da própria personagem. $\mathrm{O}$ mecanismo é mais subjetivo, e as oscilações menos justificáveis.

Um dos caminhos para entender de maneira mais profunda as instabilidade de Lúcia é o da multiplicação dos olhares narradores. Nos "perfis" de Alencar, as motivações das heroínas Lúcia, Aurélia e Diva variam entre polos aparentemente inconciliáveis que forjam um comportamento enigmático cuja decifração cabe ao par amoroso (Paulo, Seixas, Augusto) e, em última instância, ao leitor. No entanto, no caso de Lúcia, o conflito entre as diferentes opiniões e pontos de vista divergentes (Paulo, Sá, Couto, Cunha) sugere, na opinião de Dante Moreira Leite, que o desvendamento da heroína só pode se dar "por meio da interação e e/ou da percepção do outro"130 . Como já foi dito, é o olhar provinciano (e puro) de Paulo que - ignorante dos códigos sociais consegue fazer reavivar na cortesã a menina pura. (“Tu me santificas-te com teu primeiro olhar!"131 - afirma a heroína). No entanto, as diferentes vozes da cidade interferem o tempo todo provocando, segundo Dante, um "desvio" na maneira como ela é enxergada por Paulo. O tour de force de Lúcia - pelo menos na primeira metade da

129 COUTINHO, Afrânio (org). A Polêmica Alencar-Nabuco, op. cit, p.138.

130 Dante Moreira Leite chega a sugerir que por meio desse artifício Alencar estaria apresentando, intuitivamente, um modelo de caráter que dialoga com as bases da psicologia que seria desenvolvida no século XX, o que leva o crítico a considerá-lo mais moderno que Machado da Assis. In: Psicologia e Literatura. São Paulo: Unesp/ Ucitec, 1987.

131 Lucíola, p. 329. 
narrativa - é o de tentar manter em Paulo a primeira impressão que causou; enquanto, em uma espécie de alienação de si mesma, monta uma "personalidade de circunstância" (a expressão é de Antonio Candido) para fazer às vezes de cortesã. Tudo isso, permeado por um processo paralelo de autoconhecimento. Assim, segundo Dante Moreira Leite, as oscilações da heroína seriam resultantes "não de uma personalidade doentia, mas da maneira pela qual se vê através de Paulo", o que leva o crítico a considerar Lucíola um romance "estranhamente moderno" 132

Nas páginas que se seguem, o trabalho buscará analisar as oscilações da heroína levando em consideração os aspectos mais subjetivos de seu comportamento, em uma tentativa de compreender a complexidade psicológica que se esconde por trás da camada arquetípica. Para tanto, procuraremos analisar de maneira mais detalhada a trajetória da personagem, dando especial atenção aos momentos em que a heroína se encontra em "crises de identidade".

Na primeira vez em que Lúcia recebe Paulo em sua casa, a heroína apresenta-se ao rapaz da maneira como gostaria de ser vista por ele. Suas vestes compõem um quadro de pureza e a expressão de se rosto exala, na opinião de Paulo, "um casto e ingênuo perfume". Ao ser surpreendida pelo olhar de Paulo voltado para o contorno do seio que se faz mostrar acidentalmente quando a gola do roupão azul abre-se, a cortesã enrubesce-se "como uma menina". O perfume, o rubor e as roupas, funcionam como uma linguagem pela qual a heroína expressa sua pureza d'alma. Depois de uma tarde de conversas tranquilas, Paulo, confuso com a imagem absolutamente contrária às suas expectativas, deixa a casa de Lúcia sem mencionar o motivo da visita, o que aparentemente alimenta na cortesã as esperanças de "sentir-se amada sem interesse",

No dia seguinte, após certificar-se mais uma vez com Sá do papel que a moça ocupava na sociedade, Paulo volta à casa de Lúcia decidido a reabilitar-se de sua "estúrdia ingenuidade". No primeiro contato físico com o futuro amante, a cortesã retrai-se defensivamente. O corpo furta-se ao abraço, as mãos "frias e trêmulas" sinalizam o constrangimento e o nervosismo de Lúcia ao pressentir que é chegado o

132 LEITE, Dante Moreira. Psicologia e Literatura, op. cit., p.155.

133 Lucíola, p. 236 e 238, respectivamente. 
momento de representar seu papel habitual. Algum tempo depois, diante da primeira investida concreta de Paulo, a palidez, as palpitações e o choro da heroína parecem demonstrar um esforço involuntário de impedir a carne de ser possuída:

Com o meu primeiro movimento, Lúcia cobriu-se de ardente rubor; e deixou-se ir sem a melhor resistência, com um modo de tímida resignação. Quando porém os meus lábios se colaram na tez de cetim e meu peito estreitou as formas encantadoras que debuxavam a seda, parece-me que o sangue lhe refluía ao coração. As palpitações eram bruscas e precipites. Estava lívia e mais branca que o alvo colarinho de seu roupão. Duas lágrimas em fio, duas lágrimas longas e sentidas, como dizem que chora a corça expirando, pareciam cristalizadas sobre a face, de tão lentas que rolavam. ${ }^{134}$.

Incapaz de compreender o comportamento de Lúcia, Paulo irrita-se e afasta-se revoltado. A heroína, por sua vez, toma consciência da aparente incoerência de sua atitude e, trêmula e submissa, pede perdão: "Não se agaste comigo![...] Sei o que valho e não sou capaz de iludir ninguém, muito menos ao senhor”. Paulo, ainda impaciente, põe as cartas na mesa, acabando de vez com o que considera uma "comédia de amor": "sabemos o que me traz à sua casa [...]. Incomodava-me a ideia de pensares que estava disposto a te fazer a Corte. Seria soberanamente ridículo para nós dois”.

Ao ouvir a frase incisiva de Paulo, a cortesã, como em uma espécie de transe, entra em ação. O riso estridente e o olhar vivo e cintilante marcam o início da transfiguração da heroína, o rosto é iluminado por um "fulgor estranho", o talhe arqueia-se, os movimentos, antes suaves, tornam-se enérgicos e ríspidos. Toda a cena parece tomada por uma atmosfera de tensão e crispação. É a mulher-demônio que apresenta-se a Paulo, convidando-o para a alcova.

Era outra mulher.

$\mathrm{O}$ rosto cândido e diáfano, que tanto me impressionou à doce claridade da lua, se transformara completamente: tinha agora uns toques ardentes e um fulgor estranho que o iluminava. Os lábios finos e delicados pareciam túmidos do desejo que incubavam. Havia um abismo de sensualidade da narina que tremiam com o anélito do

134 Luciola, p.240/241. Grifos meus. 
respiro curto e sibilante, e também nos fogos surdos que incendiavam a pupila negra. [...] Às vezes um tremor espasmódico percorria-lhe todo o corpo, e as espáduas se aconchegavam como se um frio de gelo a invadira de súbito; mas breve sucedia a reação, e o sangue abrasando-lhe as veias, dava à branca epiderme reflexos de nácar e às formas uma exuberância de seiva e de vida, que realçavam e irradiante beleza. ${ }^{135}$

A sequência de cenas acima descritas, bem como o movimento da narrativa como um todo, vão de encontro à tese de Dante Moreira Leite de que a personalidade de Lúcia é moldada a partir do olhar do outro, sobretudo, evidentemente, do olhar do amado. Subentende-se que a maneira respeitosa com que Paulo dirigiu-se a ela durante duas das ocasiões em que se encontraram anteriormente - no episódio da rua das Laranjeiras e na festa da Glória - despertaram em Lúcia uma espécie de "redescoberta" de si mesma que se prolonga durante as primeiras visitas nas quais a heroína aparentemente "esquece-se do seu papel” e age como moça pura. Algum tempo depois, ao constatar que Paulo deseja-a apenas enquanto corpo, assim como os demais clientes, Lúcia desfaz-se da ilusão e, em um mecanismo de autodefesa (ou autopunição, como afirma Antonio Candido ${ }^{136}$ ), veste novamente a máscara da cortesã, incorporando até o extremo a personagem bacante. Desta forma, ficam explicitadas as duas personalidades de Lúcia: a primeira real, que corresponde-lhe à alma, é nobre e pura; a segunda, "de circunstância", que, quando necessário, sobrepõem-se a primeira em um recurso de, segundo Antonio Candido, “ajustamento profissional”. A divisão é tão estanque que, como mencionado no capítulo anterior, às duas personalidades efetivamente separam-se ao final da narrativa desdobrando-se em duas identidades distintas: Lúcia e Maria da Glória.

No entanto, a tentativa de enxergar-se e adequar-se aos olhares alheios não parece esgotar completamente as justificativas para as oscilações da heroína. Como

135 Lucíola, p. 242.

136 "A vigorosa luxúria com que subjugava os amantes é um recurso de ajustamento por assim dizer profissional, $[\ldots]$ quase de imposição de uma personalidade de circunstância que se amoldasse à lei da prostituição, preservando intacta a pureza que hibernava sobra o estardalhaço da mundana. Por outras palavras, a sua sensualidade desenfreada nos aparece como técnica masoquista de reforço do sentimento de culpa, renovando incessantemente as oportunidades de punição". CANDIDO, Antonio. "Os Três Alencares". In: A Formação da Literatura Brasileira. São Paulo: Ouro Sobre Azul, 2000, p. 543. 
observou Maria Cecília Queirós Pinto, a discrepância entre os dois eus de Lúcia - o eu verdadeiro e bom e o $\mathrm{eu}$ circunstancial - só poderia ser considerada determinante na construção do caráter da personagem "se não houvesse a irrupção de um no outro"137 o que ocorre inesperadamente no final da narrativa, durante o processo de expiação.

Pouco mais de mês após haver iniciado sua "nova existência", a protagonista, já afastada dos olhares da cidade, havia assumido definitivamente a identidade anterior à prostituição e revivia, na interpretação de Paulo, "a mocidade interrompida". Os trajes singelos e sóbrios já descritos no capítulo anterior, os hábitos simples, a recusa às investidas amorosas de Paulo, deixavam claro que a heroína abandonara definitivamente a personalidade da cortesã para transformar-se na "doce e terna amiga". No entanto, em meio ao idílio inocente e fraterno do casal, depois de alguns dias de cama por conta de um mal-estar, a metade luxuriosa irrompe subitamente no corpo da jovem pura sugerindo que o seu lado bacante, ao invés de morto, estaria apenas "adormecido". Em uma espécie de frenesi que dura alguns instantes, a cortesã joga-se aos braços do amado ofertando-lhe os beijos que há poucos minutos recusava.

De repente Lúcia atirou-se a mim. Com uma arrebatada veemência esmagou na minha boca os lábios túrgidos, como se os prurisse fome de beijos que a devorava. Mas desprendeu-se logo dos meus braços, e fugiu veloz, ardendo em rubor, sorvendo num soluço o seu último beijo. Fugiu, e ao passar fechou a porta que comunicava com o interior $^{138}$.

Quando a porta abre-se novamente, Lúcia aparece trazendo a irmã pelo braço e, no rosto, a mesma expressão de "casta serenidade" que apresentava momentos antes. Paulo, mais uma vez, apresenta-se perplexo diante da mulher-esfinge, enigmática e incompreensível:

Procurei debalde, sob aquela calma aparência, um vestígio das emoções recentes; a tranquilidade vinha do íntimo, exalava dos seios d'alma, e difundia-se brandamente por toda a sua pessoa. Julgaria que nada tinha se passado, se as lágrimas já estanques não houvessem

137 PINTO, Maria Cecília Queiroz de Moraes. Alencar e a França-perfis, op. cit, p.108.

138 .Lucíola, 324. 
empanado a habitual limpidez de seu olhar. ${ }^{139}$

A permanência do comportamento volúvel e contraditório da heroína, que se mantêm mesmo quando o conflito entre os diferentes olhares e opiniões não existe mais, demonstra, a nosso ver, que a chave para a compreensão desta heroína de Alencar se encontra menos no jogo entre a essência e a aparência, e mais em uma tentativa do autor de dialogar com os conceitos utilizados pela medicina oitocentista para qualificar o comportamento feminino, em especial, no que se refere à histeria. As minúcias da descrição do corpo de Lúcia no embate com a sexualidade, o rubor, as contrações, as palpitações, os "tremores espasmódicos" que tomam conta da heroína nas cenas acima citadas parecem ilustrar o que o discurso médico oitocentista qualificava como "convulsão histérica".

\subsection{O excesso.}

Como buscou-se demonstrar no primeiro capítulo, uma dos artifícios que fundamentou a construção de uma ciência sexual ao longo do século XIX foi a "histerização" do corpo feminino. No discurso da medicina oitocentista a crise histérica era comumente caracterizada pela experiência convulsiva, um fenômeno que atraia a atenção dos médicos por seu caráter imprevisível, enigmático e potencialmente erótico. Músculos retraídos, tremores, paralisias, espasmos, alterações bruscas de temperatura, são descritos como os principais sintomas destes ataques que, de acordo com os médicos, acometiam quase exclusivamente as mulheres por serem elas portadoras de um determinado "excesso" sexual que deveria ser controlado.

Magali Engel, em Meretrizes e Doutores: saber médico e prostituição no Rio de Janeiro (1840 - 1890), demonstra que a associação entre histeria e prostituição aparece de forma expressiva nos tratados médicos veiculados em diversas publicações no Rio de Janeiro oitocentista e, sobretudo, nos Anais da Academia de Medicina a partir da década de $40^{140}$. A prostituta, encarnando o extremo oposto da mulher esposa e mãe,

139 Lucíola, p.324..

140 Engel cita pelo menos três publicações de grande repercussão no Rio de Janeiro em meados do século: A Revista Médica Fluminense, que circulou de 1835 a 1841; a Revista Médica Brasileira, considerada uma espécie de continuação da anterior, que circulou em 1841 em três volumes, e os 
representaria a histeria em sua plenitude. Seu corpo impregnado de uma sensualidade bruta, excessiva, descontrolada é figurado como o cenário ideal para as crises e os ataques nervosos.

Lúcia é uma prostituta, porém uma prostituta de "alma pura", possuidora de "germes de virtude que não podiam ser arrancados"141. Este paradoxo intensifica ainda mais o fenômeno, já que para além do suposto "descontrole sexual", há o embate entre o corpo e a alma que estão eternamente em conflito. Por isso, sempre que é convocada a assumir o papel da cortesã, o corpo da heroína enrijece-se, contrai-se, contorce-se em "câimbras pungentes", adquire uma "elasticidade nervosa e convulsa" e algumas vezes parece ser tomado por um "choque elétrico" $" 142$.

Gladys Swain, em um esclarecedor artigo sobre as transformações no conceito de histeria durante o século XIX, explica que o discurso médico, durante quase todo o século, atribuiu ao ataque histérico uma caráter de despossessão, como se o corpo da mulher, durante a experiência convulsiva, estivesse sendo atravessado por outro corpo, que fosse capaz de agir de forma autônoma. Um corpo que pertence à própria mulher, mas que, impossível de ser controlado, torna-se "suscetível de dilacerá-la".

O que é afetivamente a experiência convulsionaria? É a manifestação de uma despossessão corporal, a própria expressão da alteridade do corpo ou da transcendência do "si mesmo". Seu corpo escapa a você, se subtrai a seu controle. Ele mostra visivelmente que vive sua própria vida, que está sempre pronto a não obedecer mais àquele que o possui. $^{143}$

Esse corpo que escapa à própria mulher era, na concepção dos médicos, a própria natureza primitiva que habitaria o organismo feminino e que a qualquer momento poderia extravasar, desviando a mulher de seu destino de esposa e mãe e aproximando-a da animalidade. Tratava-se de uma reiteração da teoria do "furor

Anais de Medicina Brasiliense que se iniciaram em 1845 e se estenderam até o final do século. ENGEL, Magali. Meretrizes e Doutores - saber médico e prostituição no Rio de Janeiro (18401890). São Paulo: Brasiliense, 2004.

141 Lucíola, p. 317.

142 Idem, p. 243 e 307, respectivamente.

143 SWAIN, Gladys. "A Alma, a Mulher, o Sexo e o Corpo". In: O Feminino: Aproximações. BIRMAN, Joel e NICÉAS, Augusto (org.). Rio de Janeiro: Campus, 1986, p.19. 
uterino" desenvolvida por Platão. No entanto, mais do que o útero, era como se todo o corpo feminino, e em especial, o aparelho reprodutor, portador de mecanismos misteriosos e imprevisíveis como a natureza, pudesse, quando contrariado, fugir ao controle da mulher e dos próprios médicos. Para Swain, portanto, a concepção da histeria no século XIX se fundamenta em um embate fundamental: "a luta da mulher contra a força autônoma que nela reside e trabalha ${ }^{144}$.

Há diversos momentos da narrativa em que Lúcia parece ter sido tomada por essa "força autônoma" chegando, inclusive, aos limites da perda de consciência. O principal deles é certamente o episódio do espetáculo erótico na casa de Sá, já citado na capitulo anterior. A moça em cujo olhar resplandecia um orgulho satânico, que salta sobre a mesa despindo-se lascivamente diante dos convidados, nada tem em comum com a "amorosa donzela" com quem Paulo relacionava-se antes e depois da cena. São "Sapho e Virginia", "Messalina e Julieta", como apontou Artur Mota. Em verdade, neste episódio mais do que em qualquer outro, o corpo da cortesã parece, de fato, agir por conta própria, como se ela estivesse em um grau extremamente elevado de entorpecimento, uma espécie de transe:

\footnotetext{
Agitando as longas tranças negras, que se enroscavam quais serpentes vivas, retraiu os rins num requebro sensual, arqueou os braços e começou a imitar uma a uma das pinturas; mas imitar com a posição, com o gesto, coma sensação do gozo voluptuoso que lhe estremecia o corpo, com a voz que expirava no flébil suspiro e no beijo soluçante, com a palavra trêmula que borbulhava dos lábios no delíquio do êxtase amoroso ${ }^{145}$.
}

Além da retração, do estremecimento, enfim, de toda a agitação nervosa que toma conta do corpo da heroína neste episódio, outro fator que evidencia claramente a "despossessão" de Lúcia é o estado de alienação em que ela se encontra ao final do espetáculo quando, ao derrubar na cadeira um corpo inerte "sem articulações", olha para a poltrona que Paulo ocupava há alguns minutos e balbucia: "quem estava ali?". Em seguida, caminha para o jardim e cai "extenuada" sobre um banco de relva. Ao

144 SWAIN, Gladys. "A Alma, a Mulher, o Sexo e o Corpo". In: O Feminino: Aproximações, op. cit, p. 21. 145 Lucíola, p.242. Grifos meus. 
tomá-la em seus braços, Paulo, mais uma vez, descreve os sintomas de uma aparente "crise de nervos":

metiam dó as contrações nervosas que crispavam seu belo corpo, e os soluços de angústia que lhe partiam o seio, e cerravam a garganta, sufocando-a. Penou assim um tempo longo, em que receei por vezes que expirasse sobre meu peito. Finalmente a crise passou; foi se acalmando, e desfaleceu. ${ }^{146}$

É importante lembrar aqui, mais uma vez, que o ambiente da ceia na casa de Sá, a decoração, o grupo de pessoas presente, a atmosfera de luxúria e devassidão já descrita no capítulo anterior, são fatores que contribuem significativamente para que a moça pura dê lugar à bacante. Nesse sentido, a teoria da continuição da personalidade da heroína por meio da interação com o outro, desenvolvida por Dante Moreira Leite, volta a sem encaixar em nossa análise. É no jardim, longe dos olhares dos convidados de Sá, longe do ambiente contaminado de vícios, que a heroína consegue recuperar sua consciência. Isso explica porque na segunda parte da obra, as crises nervosas de Lúcia diminuem. Distanciando-se do ambiente corrompido da cidade e livre dos "estímulos", ela recupera a calma e a serenidade. O que nos faz lembrar novamente a metáfora usada pela própria heroína em um momento de auto-análise: “A lama deste tanque é meu corpo: enquanto a deixam no fundo e em repouso, a água está pura e límpida! ${ }^{147}$

Na segunda parte da obra, recuperando, ainda que apenas para si e para Paulo, a inocência perdida, transformando-se na moça recatada, de hábitos simples e reclusos, Lúcia deixa de ser figurada como vítima de um organismo descontrolado. No entanto, ainda assim, a imagem da heroína continua a ser construída dentro do universo da patologia. À medida que deixa de encarnar a mulher hipersexualizada, Lúcia passa, na segunda parte da obra, a personificar outro extremo do lugar destinado à mulher na ideologia oitocentista: a mulher "frígida", quase assexuada, aquela cujo contato com o corpo masculino, ainda que seja o do objeto amado, gera angústia e sofrimento.

146 Lucíola, p. 259. Grifos meus.

147 Idem, p. 311. 


\subsection{A falta.}

Procuramos demonstrar no primeiro capítulo neste trabalho que o adestramento da sexualidade feminina durante o século XIX se deu por uma via de mão dupla. Se por um lado a medicina oitocentista desqualificava o corpo feminino como um corpo impregnado de sexualidade e difundia a imagem da mulher como um ser refém da própria natureza primitiva; por outro lado, havia um esforço para direcionar a sexualidade feminina para o leito conjugal, em uma estratégia que valorizava a maternidade transformando-a em uma tarefa santa capaz de libertar as mulheres do pecado original. Assim, a imagem da mulher, no século XIX, duplicava-se: as mulheres "reais" eram vistas como seres imprevisíveis e ameaçadores, portadores de uma essência maléfica incontrolável. Ao mesmo tempo, a imagem da mulher ideal passava a ser a da esposa frágil, submissa, passiva e abnegada, construída com base no modelo mariano que, embora inalcançável, deveria, como mencionamos anteriormente, servir como norte para todas as mulheres que desejassem a salvação.

Com base neste raciocínio, boa parte dos médicos no século XIX passava a defender a hipótese de que as mulheres fossem seres naturalmente assexuados, frígidos, ou anestesiados sexualmente. Ainda que outras vertentes da medicina oitocentista buscassem mecanismos para combater a chamada "frigidez" feminina incentivando a sexualidade conjugal, a figura da mulher frígida, por se contrapor à da mulher de sexualidade livre, adquiria, especialmente por meio do discurso religioso, ares de santidade. Segundo Silvia Alexim Nunes, a mulher frígida era, na ideologia oitocentista, "quase a Virgem na Terra", era "a mulher santa, a mulher honrada."148

Ao iniciar o seu processo de expiação, abrindo mão da casa, das vestes, dos hábitos mundanos, Lúcia - como procuramos demonstrar no capítulo anterior transforma-se gradativamente no perfil de mulher que a igreja esforçava-se em divulgar como o ideal: a mulher afastada do mundo, avessa à vaidade e as coqueterias, submissa, abnegada e, acima de tudo, assexuada. Imersa em sua trajetória de sacrifício e reclusão, Lúcia passa a ser figurada como uma espécie de "santa" e traz, no corpo gelado, os

148 NUNES. Silvia Alexim. O Corpo do Diabo entre a Cruz e a Caldeirinha - um estudo sobre a mulher, o masoquismo e a feminilidade. Rio de Janeiro:Civilização Brasileira, 2000, p. 77. 
indícios da frigidez:

À noite, quando voltei, queixava-se de ligeira disposição. Repeliu-me ainda: só abracei um corpo convulso e gelado que me assustou; sobretudo quando, levando as mãos à cabeça, soltou um gemido e doloroso. ${ }^{149}$

A palavra frigidez vem de frigi, do latim: frio. O corpo "frio", portanto, "frígido" era caracterizado como o corpo insensível, onde o desejo - simbolizado desde a antiguidade clássica pela imagem do "fogo" - se ausentava completamente. A variação de temperatura da pele da personagem é mais um dos elementos utilizados por Alencar para, durante toda a narrativa, distinguir o anjo da bacante. $\mathrm{O}$ "ardente rubor" que cobria o corpo da heroína nos momentos de luxúria dá lugar à frieza que durante o processo de expiação, segundo Paulo, "aumentava de dia a dia" até atingir um aspecto cadavérico.

Há de ter ouvido falar na sensualidade nefanda dos coveiros de cemitério, que saciavam no cadáver das belas mulheres um desejo brutal. Não creio que esses abutres da lascívia apertassem corpo mais gelado e insensível do que a múmia que se inteiriçava nos meus braços. Senti o horror de Virgílio correr-me pela medula dos ossos ${ }^{150}$

A frigidez, em última instância, apresenta-se, no imaginário oitocentista, como uma forma elevada, e às vezes excessiva, de pudor: o "véu sutil que resguarda a fraqueza da mulher" ${ }^{151}$. No século XIX, o pudor feminino ligava-se diretamente à contenção sexual e era extremamente valorizado, tanto na sociedade fluminense de modo geral, quanto, evidentemente, na literatura. Já mencionamos que, para Alencar, a "virgindade é um talismã", e suas personagens perdem o interesse a partir do momento que deixam de ser donzelas. Dessa forma, grande parte das heroínas alencarianas apresenta graus elevados de pudor. Amélia, de Encarnação e Guida, de Sonhos D'Ouro fazem o possível para adiar o casamento desejando "conservar-se criança além do período natural da infância ${ }^{152, ;}$ B Berta, a “Til”, e Dona Flor, de O Sertanejo, renunciam a ele completamente; Aurélia veda a alcova, preservando a castidade mesmo depois do

149 Lucíola, p. 297. Grifos meus.

150 Idem, p.307. Grifos meus.

151 Idem. p. 236

152 ALENCAR, José de. Encarnação. In: Obra Completa, vol. I, op. cit., p. 846. 
matrimônio. A recusa faz com que as heroínas, já belas e caprichosas, adquiram, aos olhos dos leitores oitocentistas, certa aura de altivez, de integridade, com se pairassem acima das mulheres "normais" por serem capazes de controlar seus impulsos.

Convém lembrar que, em meio a tantas criaturas recatadas, pelo menos uma, além de Lúcia, leva o pudor até os limites da frigidez. É o caso de Emília, "a estátua de gelo", a moça para quem o simples contato com o corpo masculino, gerava ataques de cólera.

Emília não valsava; nunca nos bailes ela consentiu que o braço de um homem lhe cingisse o talhe. Na contradança a ponta dos seus dedos afilados, sempre calçados de luvas, apenas roçavam a palma do cavalheiro: o mesmo era quando aceitava o braço de alguém. Bem diferente nisso de certas moças que passeiam nas salas reclinadas ao peito de seus pares, Emília não consentia que a manga de uma casaca roçasse nem de leve as rendas de seu decote ${ }^{153}$.

As motivações para a suposta "frigidez" de Emília remontam também aos psicologismos dos alienistas da época. A heroína, ainda menina, adoece seriamente e recebe a visita de Augusto, um jovem médico amigo da família. Ao acordar, é surpreendida com o toque do rapaz que encostava o ouvido em seu corpo para escutarlhe o peito. A partir daí desenvolve-se a neurose de Emília, que se manifesta como um sentimento de repulsa por todos os homens que a cercam, especialmente por Augusto, a quem submete a constantes humilhações. À medida que a narrativa evolui a heroína passa a ser figurada como uma espécie de vestal, transforma-se na "diva", virgem e sagrada, "velando-se como às mártires do cristianismo para morrer pudicamente" ${ }^{154}$. No entanto, Alencar, provavelmente bastante atento às normas higiênicas, sabe que o excesso de contenção não deveria ser incentivado, já que, como mencionamos, a ideologia da época determinava que a sexualidade conjugal direcionada para procriação deveria ser salvaguardada para o bem do Estado. Por isso, Emília acaba convencendo-se de seu amor por Augusto e vence a barreira da recusa ao final da narrativa. A moça insubmissa e arredia, histérica à sua maneira, é "curada" pelo amor de um homem e deverá seguir o destino tradicionalmente reservado às mulheres no século XIX: o

153 ALENCAR, José de. Diva. In: Obra Completa, vol. I, op. cit., p.346.

154 Ibidem, p. 339. 
casamento e os filhos.

Para Lúcia, no entanto, a possibilidade de casar e gerar filhos não existe, já que, apesar da aura de santidade posteriormente adquirida, ela é, e continuará sendo, também a cortesã, a bacante, a moça eternamente refém da natureza primitiva e descontrolada. Prova disso, lembremos-nos, é a irrupção inesperada da personalidade luxuriosa na moça pura ao final da narrativa, mostrando que Maria (a parte boa) não havia conseguido livrar-se inteiramente de Lúcia (a parte ruim). Além disso, ainda que a personagem conseguisse manter a alma pura, o corpo estaria para sempre marcado pela vida anterior, corrompido pelo histórico de luxúrias e depravações.

\subsection{O corpo, o pecado e a moralidade.}

É o grande respeito, a espécie de culto, que o homem civilizado consagra à mulher. Entre os povos bárbaros ela é apenas escrava ou amante; o seu valor está na sua beleza. Para nós, é a tríplice imagem da maternidade, do amor e da inocência. Estamos habituados a venerar nela a virtude na sua forma mais perfeita. Por isso na mulher a menor falta mancha também o corpo, enquanto que no homem mancha apenas a alma. A alma purifica-se porque é espírito, o corpo não!... Eis por que o arrependimento apaga a nódoa do homem e nunca a da mulher; eis porque a sociedade recebe o homem que se regenera, e repele sempre aquela que traz em sua pessoa os traços indeléveis de seu erro

(José de Alencar, “As Asas de um Anjo”)

Magali Engel, no trabalho já mencionado, explica que, nos textos sobre a prostituição que circulavam no Rio de Janeiro entre 1840 e 1890, a livre manifestação da sexualidade desvinculada da função reprodutiva era tida como o principal fator responsável pelas doenças e pela degeneração física dos indivíduos. O corpo da prostituta, considerado um foco de transmissão de moléstias venéreas, entre elas a sífilis, passa a ser visto como o maior inimigo de uma sociedade sadia, já que promovia a "degeneração das raças". ${ }^{155}$ De acordo com Engel, o exercício da sexualidade de forma descontrolada, a falta de sono, a má alimentação, a precariedade de asseio que caracterizavam, na concepção dos médicos, o

155 ENGEL, Magali. Meretrizes e Doutores - saber médico e prostituição no Rio de Janeiro (18401890), op. cit, p. 77. 
estilo de vida das prostitutas, produziriam corpos débeis, adoecidos e envelhecidos prematuramente. No romance de Alencar, Paulo, na tentativa de definir para Sá o comportamento de Lúcia, ilustra claramente este discurso:

É uma moça gasta pelos prazeres: ainda jovem do corpo, mas velha n'alma. [...] Eis o que é Lúcia; daqui a algum tempo o hábito fará dela o mesmo que tem feito das outras: envelhecerá o corpo, como já envelheceu a alma. ${ }^{156}$

A ideologia que sustenta o corpo das cortesãs com "gastos", corrompidos pelos "excessos" faz com que elas incorporem também o estigma da infertilidade. Ainda de acordo com Engel, no discurso médico oitocentista, a perversão sexual - identificada à vida "desregrada" ou aos "excessos inerentes à vida da voluptuosidade" - cria na mulher "a incapacidade física para conceber e/ou gerar um filho""157. Lúcia parece introjetar este discurso quando, comparando-se à personagem Átala, de Chateaubriand, sugere, de maneira metafórica, uma das motivações que jazem ocultas por trás das constantes recusas às investidas de Paulo. Referindo-se ao amor assexuado dos jovens indígenas, a heroína divaga:

_ Não podíamos viver assim?

_. Átala tinha um motivo para resistir, Lúcia.

_ E eu não tenho?

_ Ela obedecia a um voto; e a virgindade lhe servia de defesa.

Lúcia respondeu arrebatadamente:

_ Alguns espinhos que cercam a rosa, valem o veneno de certas flores? Um voto é coisa santa; mas a dor da mãe que mata seu filho é horrível.

_ Não te entendo![...]

_ Queria dizer que se eu fosse Átala poderia perder a minha alma para dar-lhe a virgindade que não tenho; mas o que eu não posso é separarme deste corpo! 158

Como podemos perceber, na opinião de Lúcia, os destinos dela e de Átala unemse pela interdição ao sexo. A interdição da heroína de Chateaubriand vem da promessa

156 Lucíola, p. 267.

157 ENGEL, Magali. Meretrizes e Doutores, op. cit, p.79.

158 Lucíola, p.305. 
feita por sua mãe à Virgem; a interdição de Lúcia - ainda não aceita e compreendida por Paulo - é a possibilidade de gerar um filho no corpo corrompido, causando-lhe a morte. No discurso da cortesã fica explicitada a relação entre a prostituição e a degeneração física. Para Lúcia, seu corpo é portador de um "veneno" o que o torna ainda mais repulsivo do que o corpo da heroína indígena protegido pelo voto sagrado. Além disso, fica evidenciada na fala de Lúcia a consciência de que, por mais que se esforce pra recuperar o melhor de si em seu processo de purificação e martírio, a regeneração completa é impossível já que o corpo, do qual não pode separar-se, estará para sempre marcado pelo pecado. Mais adiante, a heroína transforma-se, mais uma vez, em portavoz do o discurso médico e religioso:

\footnotetext{
_Quando me lembro que um filho pode gerar-se das minhas entranhas, tenho horror de mim mesma! [...] Oh! Um filho, se Deus mo desse, seria o perdão da minha culpa! Mas sinto que ele não poderia viver no meu seio! Eu o mataria, eu, depois de o ter concebido! ${ }^{159}$
}

Por trás discurso fisiológico que desqualifica o corpo da prostituta como um corpo "doente" e, portanto, inapto para a maternidade, há, evidentemente, uma estratégia de punição da mulher que exercita uma sexualidade "desviante". A maternidade, considerada "um presente de Deus", "uma benção divina", jamais poderia ser concedida àquela cuja existência esteve, em algum momento, imersa em pecados. Em outras palavras, os esteriótipos da mulher-mãe e da mulher-bacante, na ideologia oitocentista, não poderiam, de modo algum, habitar o mesmo corpo.

Assim, as suspeitas da heroína se confirmam. Lúcia, de fato, engravida e, ao sentir o primeiro movimento do filho, se desespera e perde os sentidos. Em meio a mais uma das crises nervosas habilmente descritas por Alencar, a heroína reforça o discurso proferido anteriormente: "Eu adivinhava que ele me levaria consigo [...] Ele morreu! [...] E fui eu que o matei ${ }^{160 ", ~ A t e n d o-s e ~ c a d a ~ v e z ~ m a i s ~ a ̀ ~ c o n v i c c ̧ a ̃ o ~ d e ~ q u e ~ o ~ c o r p o ~}$ "envenenado" havia matado a criança, Lúcia adoece e, ao ser informada de que

159 Lucíola, p.309.

160 Idem, p. 328. 
precisaria expelir o feto para livrar-se da febre, nega-se a fazê-lo. Em uma última provação da trajetória de martírio e de expiação, a heroína sacrifica a própria vida pelo filho que já não vive. ("Iremos juntos! ...[...] Sua mãe lhe servirá de túmulo") ${ }^{161}$. A dor, o sofrimento, o sacrifício, o espírito de abnegação demonstrados nesta cena encaixamse perfeitamente no ideal de feminilidade pregado pela Igreja em meados do século.

A maternidade, esse "sublime sentimento" a que, segundo Paulo, todas as mulheres almejam ${ }^{162}$, é a última e a maior das punições para o anjo caído (assim como o casamento, segundo Alencar, foi para Carolina), mas é também o que permite com que a heroína, libertando-se do corpo corrompido, atinja a redenção. A morte de Lúcia traz as características físicas e sensoriais que acompanham as grandes experiências místicas:

Lúcia pedia-me que abrisse a janela: era noite já; do leito víamos uma zona de azul na qual brilhava límpida a serena a estrela da tarde. Um sorriso pálido desfolhou-se ainda nos lábios sem cor e sublime êxtase iluminou a suave transparência de seu rosto. A beleza imaterial dos anjos deve ter aquela divina limpidez.

_ Recebe-me... Paulo!.... ${ }^{163}$

O "êxtase sublime" que ilumina o rosto da heroína, a luz azul comumente descrita em relatos de elevação espiritual e o aspecto angelical que adquire a cortesã no momento da morte, não deixam dúvidas: a alma da heroína está "salva". Arrependendose, e abandonando a vida de pecados, Lúcia, tal qual a Madalena do Evangelho, purifica-se e adquire o perdão divino, ainda que para isso tenha sido punida até a morte. Neste sentido, o objetivo de Alencar em Lucíola, parece ser precisamente o mesmo daquele levado a cabo quatro anos antes na peça "As Asas de um Anjo": "percorrer a existência tumultuária desde o dia em que o anjo perdendo as asas cai no pó até o momento em que, depois de haver rogado como a larva pelo chão, se transforma enfim e eleva à mansão da virtude"164.

Elevar uma cortesã à "mansão da virtude" dentro de um cenário católico e conservador como o Rio de Janeiro oitocentista, por si só, não era tarefa fácil. Alencar,

161 Lucíola, p. 329.

162 Idem, p. 309.

163 Idem, p. 330/331.

164 ALENCAR, José de. Pós-escrito de “A Expiação”. In: Teatro Completo, vol. II. op.cit, p. 376. 
como mencionado, já havia experimentado as consequências desta ousadia com a peça censurada. Integrar a mulher perdida à sociedade seria pedir demais a um escritor tão rigidamente preocupado em respeitar as "convenções sociais". Assim, apesar da regeneração, é negado a Lúcia o direito ao amor ("O amor para uma mulher como eu seria a mais terrível punição que Deus poderia infligir-lhe"), o direito à maternidade, e o direito de viver perto dos olhares da coletividade. Por mais "santa" que fosse aos olhos do narrador, a heroína seria - e deveria ser, na concepção de Alencar - para sempre condenada pela "boa sociedade". O argumento é explicitado em um trecho do discurso da personagem Menenes em "A Expiação", peça escrita como continuação de "As Asas de um Anjo". Referindo-se à súbita aparição da ex-cortesã Carolina, já "regenerada", em um baile da Corte após longo tempo de reclusão e isolamento, Meneses afirma:

\begin{abstract}
Menezes: Seu lugar não é aqui, Carolina. Os anjos não podem roçar nos tapetes de veludo que cobrem os salões; nem viver nesse espaço intermédio onde gravita a sociedade. [...] No seio da sua família, na solidão da sua consciência, no mistério de sua inteligente caridade, você é uma santa, Carolina; aqui neste baile, não passa de uma mulher infeliz que a sociedade lamenta mas condena ${ }^{165}$.
\end{abstract}

Sentencioso, Meneses é o raisonneur da peça de Alencar, "imitação do tipo Desgenais [...] é a razão social encarnada em um homem"166. O raisonneur, figura convencional na dramaturgia clássica, é, como sabemos, a personagem através da qual a voz do autor se faz presente na obra. Por meio de Menezes, portanto, temos acesso a um elemento do conteúdo ideológico dessas duas peças de Alencar, e que acreditamos estar presente também em Lucíola: a mulher "perdida", ainda que se arrependa e passe por um longo processo de expiação e martírio, ainda que abandone a vida de pecados e sinta na pele a punição pelas "faltas" cometidas, estará para sempre banida dos "tapetes de veludo". Em "As Asas do Anjo", quando Carolina questiona indignada a maneira como as cortesãs arrependidas são tratadas pela sociedade, outro trecho do discurso de Meneses evidencia ainda mais a posição de Alencar face às convenções sociais:

165 ALENCAR, José de. "A Expiação". In: Teatro Completo, vol II, op.cit, p. 391.

166 Artigo sobre "As Asas de um Anjo" publicado em 22 de junho de 1858. In: Obra Completa, vol.4, op. cit, p. 927. 
Carolina: Aquela que uma vez errou nunca mais se reabilita. Embora ela se arrependa; embora pague cada um dos seus momentos de desvario por anos de expiação e de martírio: embora, iluminada pelo sofrimento ela compreenda toda a sublimidade da virtude! ... [...] Nada disso lhe vale! Se ela aparecer o mundo arrancará o véu que cobre o seu passado.

Meneses: E assim deve ser, Carolina.

Carolina: O senhor defende essa injustiça?

Meneses: Defendo a lei social, que, na minha opinião, deve ser respeitada até mesmo nos seus prejuízos. Como filósofo, posso condenar algumas aberrações da sociedade; mas como cidadão, curvome a elas e não discuto ${ }^{167}$."

Trata-se, como podemos perceber, não exatamente de corrigir a sociedade, criticá-la, ou moralizá-la, mas de respeitá-la, “curvar-se a ela até mesmo nos seus prejuízos". Assim, pelo menos neste aspecto, é possível dizer que o peso da "lei social" na obra de Alencar tornou-se maior com o passar dos anos, pois se Carolina teve a oportunidade de regenerar-se "no seio da família", Lúcia - cuja história de vida marcada por carências e privações tornaria o concubinato mais "justificável" para a moral da época - teve de pagar com a vida as "faltas" cometidas.

De uma forma ou de outra, transferindo à sociedade a responsabilidade pelo julgamento, Alencar, nos dois casos, esquiva-se da tarefa de condenar as heroínas “santas". Vale lembrar, como observou Luis Filipe Ribeiro, que outro artifício utilizado pelo autor nesse sentido, é o de fazer com que o discurso de condenação da heroína seja proferido por ela mesma, e não pelo narrador, que, aliás, tenta convencê-la do contrário. É Lúcia quem se reconhece indigna para o amor e para a maternidade, é ela quem, rechaçando a moral da obra de Dumas Filho, afirma ser "impossível amar uma mulher que se compra"168. Paulo, por outro lado, torna-se, como observou Ribeiro, "o doador da compreensão e da santificação da mulher perdida”. É aquele que trata com "excessiva indulgência", as "criaturas que escandalizam a sociedade", e que, construindo com seu relato o "perfil de mulher", promove a reabilitação da cortesã,

167 ALENCAR, José de. "As Asas de um Anjo”. In: Teatro Completo, vol. II. Op. Cit, 245.

168 Lucíola, p.293. 
mesmo que póstuma. Com tudo isso, o narrador, assim como G.M - interlocutora cúmplice e mulher "superior", lembremos-nos - apresenta-se, observa Luis Filipe Ribeiro, como uma "consciência progressista" que destoa do cenário inquisitório do Rio de Janeiro oitocentista, enquanto o discurso da heroína, pelo menos ao final da narrativa, funde-se, mescla-se, com o conservadorismo da sociedade que a condena.

\subsection{Laivos de contestação.}

É preciso reconhecer, no entanto, que Lúcia nem sempre manifestou essa cumplicidade passiva e servil diante da sociedade que a cerca. Assim como muitas outras personagens femininas de Alencar, a heroína, em sua época de cortesã, diversas vezes colocou-se contra a moral vigente de forma agressiva, vingativa, às vezes despudorada, replicando, às gargalhadas, com frases impregnadas de sarcasmo e ironia os comentários e olhares acusadores que eram-lhe direcionados. Assim como Aurélia, que se vinga da moral do contrato utilizando-a jocosamente a seu favor, e inverte os papéis sociais tratando o futuro marido como propriedade, Lúcia surpreende justamente porque é capaz de analisar criticamente a condição em que se encontra e, ao falar abertamente sobre isso, esquiva-se do papel de vítima referindo-se ao próprio corpo como um capital a ser explorado. "É preciso pagar a conta da ceia!" - diz a Paulo, quanto este implora para que não protagonize as cenas eróticas do banquete de Sá. Em outro momento da narrativa, ao ser informada de que o sociedade exigia que rompesse a exclusividade com Paulo retomando o seu lugar nos eventos sociais da Corte, a cortesã explicita o seu caráter de mercadoria comparando-se a um carro de aluguel:

_ Ah! esquecia que uma mulher como eu não se pertence; é uma coisa pública, um carro de praça que não pode recusar quem chega. [...] Esqueci que, para ter o direito de vender o meu corpo, perdi a liberdade de dá-lo a quem me aprouver! O mundo é lógico![...]. Enquanto ostentar a impudência da cortesã e fizer timbre da minha infâmia, um homem honesto pode rolar-se nos meus braços sem que a mais leve nódoa manche sua honra; mas se pedir-lhe que me aceite, se lhe suplicar a esmola de um pouco de afeição, oh! então meu contato é como lepra para a sua dignidade e a sua reputação. Todo homem 
honesto deve repelir-me! ${ }^{169}$

O motivo que leva Alencar, nos perfis, a construir heroínas com esse comportamento aparentemente excêntrico pode, em uma primeira análise, ser compreendido pela chave do individualismo romântico. As protagonistas de Alencar têm a sua individualidade bem marcada justamente porque o autor acentua em todas elas a vontade individual, que muitas vezes é expressa em forma de capricho. Essa a opinião de Regina Pontieri, que afirma:

As heroínas alencarianas não são despudoradas só porque, de algum modo, tiram partido da ostentação da sua beleza e riqueza. Mas sobretudo porque exibem, pela palavra crítica, o conhecimento dos mecanismos sociais contra os quais se colocam. Essas mulheres são, invariavelmente, leitoras de romances em cuja conta se creditam, algumas vezes, suas ousadias verbais. E são singulares porque são excêntricas, leem o mundo de acordo com seu código pessoal ${ }^{170}$.

Se voltarmos-nos para a teoria dos "modos de ação" de Todorov trabalhada por Fernando Segolin em Personagem e Anti-personagem, podemos dizer que Alencar, seguindo a tendência da prosa de ficção romântica, reforça o "modo optativo" da vontade de suas heroínas face ao modo "obrigativo" da coerção grupal. Assim, a aura de rebeldia que as heroínas de Alencar carregam traduz a necessidade romântica de enfatizar o individualismo do herói que, por um impulso inerente à sua personalidade, se opõe às "exigências ditadas pela vontade coletiva ou por uma lei social"171 . O caráter irredutivelmente vingativo de Aurélia, a repulsa ao contato masculino de Emília, e o desprezo de Lúcia em relação a seus amantes - e, no início da narrativa, também a Paulo - podem, a nosso ver, ser vistas como estratégias sutis (como cabe às mulheres no século XIX) de se colocarem contra a sociedade que as oprime. Sociedade que é simbolizada, num sentido mais amplo, pelos valores da nova ordem burguesa: a mercantilização e a coisificação das relações humanas; e no mais restrito, à lógica do casamento por conveniência e da institucionalização do amor.

169 Lucíola, p. 279.

170 PONTIERI, Regina Lúcia. A Voragem do Olhar, p. 40.

171 SEGOLIN, Fernando. Personagem e Anti-personagem. São Paulo: Olho d'Água, 2006, p.53 
Em última instância, o que Lúcia reivindica em seu discurso efusivo é o mesmo que reivindicavam quase todas as heroínas românticas, desde suas irmãs brasileiras, até as protagonistas dos romances europeus: o direito ao amor verdadeiro, que transcenda as convenções sociais e a lógica contratual. Em outras palavras, o "sentir-se amada sem interesse" (embora ao final da narrativa - lembremos-nos - ela mesma se reconheça indigna para isso). É o desejo de "sentir-se amada sem interesse" que faz com que Lúcia aproxime-se afetivamente de Paulo oferecendo-lhe a "alma" cada vez que sente que está sendo vista como ser humano; e afaste-se dele, oferecendo-lhe o corpo, à medida que se percebe na condição de objeto. Esse jogo de tensões, entre a aproximação e o afastamento, que também caracteriza os demais "perfis" de Alencar, é responsável por grande parte do movimento dramático e é, ao mesmo tempo, onde se concentra toda a força erótica da narrativa. O amor romântico, demonstra Benedito Nunes, "tanto mais sensual é, quanto menos sexual ele quer ser"172, e envolve os amantes - e também os leitores - tanto nos momentos de entrega, quanto nos de sublimação.

No entanto, para além do temperamento excêntrico e dos revides sarcásticos que a heroína, vez ou outra, direciona à sociedade, há outro aspecto desta personagem de Alencar que não pode ser negligenciado. Trata-se da maneira com a qual a Lúcia lida com o lugar social que, por força das circunstâncias, foi levada a assumir. De acordo com Magali Engel, a prostituição no século XIX poderia ser vista como "um espaço de resistência ao ideal de mulher frágil e submissa", no entanto, revelando-se também como produto dos valores morais da época, apresenta-se, ao mesmo tempo, como "um espaço de manutenção destes mesmos valores" ${ }^{\prime 173}$. Sem dúvida nenhuma, o papel social que Lúcia assume na sociedade permite que ela goze de uma liberdade e de uma autonomia maior do que a das demais mulheres da elite fluminense (prova disso, é a aparição desacompanhada na festa da Glória, que chama a atenção de Paulo pela

172 NUNES, Benedito. “A Visão Romântica”. In: GUINSBURG, J. (org.). O Romantismo. São Paulo: Perspectiva, 1993, p.73.

173 ENGEL, Magali. Meretrizes e Doutores, op. cit. p. 27. Além de Engel, outros autores tratam da prostituição de luxo como um lugar que proporcionaria à mulher maior independência e autonomia e que funcionaria, portanto, como uma válvula de escape para a dominação patriarcal; entre eles: Simone de Beauvoir, em "Prostitutas e Hetairas", in: O Segundo Sexo, op.cit; e Luis Carlos Soares, em Rameiras, Ilhoas, Polacas...: a prostituição do Rio de Janeiro do século XIX. São Paulo: Ática, 1992. Um exemplo bastante ilustrativo desta relação na literatura brasileira do século XIX dá-se com a personagem Pombinha, do Romance $O$ Cortiço, de Aluísio de Azevedo. 
"ausência de um pai, um marido, um irmão"). Entregando-se a vários homens, a heroína - ao menos até apaixonar-se - não pertence definitivamente a nenhum; o dinheiro que junta, os bens que adquire asseguram-lhe uma independência econômica que não era permitida às suas contemporâneas. Lúcia demonstra ter consciência desta situação e valoriza sua liberdade como forma de compensação pela marginalidade que experiencia. A cortesã, como mencionado anteriormente, "não admite que ninguém adquira direitos sobre ela", desdenha dos presentes caros que recebe de seus amantes e, incapaz de defender o corpo, defende veementemente sua intimidade e o direito sobre a propriedade: "sua casa é somente sua: ela o recebe como hóspede, como dono, nunca" ${ }^{\prime 74}$. Sendo tratada como objeto, a heroína, paradoxalmente, transforma-se em sujeito.

Isso não quer dizer, no entanto, que Lúcia se sentisse confortável no papel de cortesã ou, menos ainda, que a prostituição fosse para ela uma escolha (saberemos, ao final da narrativa, que a heroína entregou-se a tal caminho por encontrar-se em uma situação limite na qual se viu como a única pessoa capaz de salvar os familiares da febre amarela). Quer dizer apenas que, ao ser levada à prostituição e consequentemente, ao ser colocada pelos preconceitos morais da época eternamente à margem da sociedade, a cortesã passa a contestar tais preconceitos em uma luta, ora voluntária, ora involuntária contra a opressão a qual é submetida e, ao mesmo tempo, tirando proveito das raras "compensações" que a situação lhe oferece.

Em última análise, os tremores espasmódicos, o entorpecimento e as crises convulsivas que Lúcia apresenta nos momentos em que é chamada ao papel de cortesã, podem ser vistos também como sinais de resistência à opressão que experiencia. Segundo Silvia Alexim Nunes, a mulher que no século XIX era qualificada como histérica, era "a mulher que buscava reagir a uma posição passiva de renúncia e submissão procurando preservar sua potência que se exprime como um protesto contra essa dominação ${ }^{175}$." Seria esse, segundo Silvia, o motivo pelo qual, os casos de histeria tenham desaparecido gradativamente à medida que as mulheres foram se emancipando. Evidentemente, não podemos afirmar que Alencar tivesse consciência deste processo, já

174 Lucíola, p. 245.

175 NUNES, Silvia Alexim. O Corpo do Diabo Entre a Cruz e a Caldeirinha, op. cit, p. 109. 
que os estudos mais aprofundados sobre a histeria só vieram a público no final do século, mas acreditamos ser possível inferir que, ao buscar retratar as "idiossincrasias", "as aberrações do viver comum ${ }^{176, ", ~ a o ~ i n s e r i r ~ s e u s ~ p e r f i s ~ n o ~ r a m o ~ d o s ~ " r o m a n c e s ~}$ fisiológicos" (termo repetidamente utilizado pelo autor para qualificar seus "perfis") e ao abordar de forma ousada questões relacionadas à opressão sexual e econômica, Alencar tenha construído personagens que demonstram uma intuição surpreendente das peculiaridades que afetavam a constituição do feminino na época.

Sob esse aspecto, Lúcia e Emília, poderiam ser consideradas as heroínas alencarianas de maior densidade e, possivelmente, as mais contestadoras, já que, ainda que muitas outras personagens femininas resistam à ordem social com atitudes excêntricas e ousadias verbais, são elas - as tais "aberrações fisiológicas" - que trazem no próprio corpo rígido, gelado e convulso, os sintomas da resistência a essa ordem. No caso de Diva, no entanto, a deficiências da própria narrativa, mais descuidada e menos ambiciosa que os demais "perfis", reduzem em grande medida a força da personagem. Em Lucíola, por outro lado, o enredo bem construído e a carga dramática da narrativa permitem que a complexidade da heroína seja explorada em todas as suas nuances proporcionando o "contorno aquilíneo" que leva Antonio Candido a enquadrar esta obra, junto a Senhora, na categoria do Alencar "dos adultos"177.

“Como então Lucíola é a mesma coisa que a Dame aux Camélias, se nesta não se encontra a questão fisiológica, ainda mais quando naquela a questão fisiológica é todo o romance?" ${ }^{178}$ - pergunta Alencar a Nabuco quando este acusa-o de plágio. Não é difícil supor a tendência a que Alencar vinha se filiando ao compor personagens tão singulares: em 1822, Stendhal já havia publicado De L'Amour que qualificou de fisiologia; em 1829, Balzac publicou A Fisiologia do Casamento que, na divisão de sua obra, se enquadra na categoria dos "romances analíticos"; nos anos seguintes Balzac publicaria ainda seus dois "Estudos de Mulher", os quais, guardadas as diferenças estruturais, certamente serviram de inspiração para os romances urbanos de Alencar.

176 "Esses perfis de mulher, como diz o termo, não são tipos; mas, ao contrário, exceções, ou idiossincrasias morais, que se tornam curiosos, justamente pela originalidade e aberração do viver comum. É assim que se deve entender Lúcia, Emília e Aurélia.”. ALENCAR, José de. Em: COUTINHO, Afrânio (org). A Polêmica Alencar/Nabuco, op. cit. 150 (grifos meus).

177 CANDIDO. Antonio. "Os Três Alencares”. In: A Formação da Literatura Brasileira”, op. cit, p. 540.

178 ALENCAR, José de. Em: COUTINHO, Afrânio (org). A Polêmica Alencar/Nabuco, op. cit. 150 
"Fisiologia", para Alencar, como sabemos, significa o estudo do caráter, do temperamento de uma pessoa ou, no caso, de uma personagem. "Confusão com a psicologia da nossa linguagem atual aplicada ao romance ${ }^{179,}$ - explica Cavalcanti Proença. Em um momento em que as descobertas de Freud e Charcot que fundamentaram a psicanálise ainda estavam longe de ser divulgadas e em que o conceito de psicologia estava ainda intimamente relacionado aos estudos do funcionamentos dos orgãos e da anatomia dos organismos, a "confusão" é perfeitamente justificável. De qualquer forma, interessa-mos mostrar que, em Lucíola, o esforço por descrever o corpo feminino no embate com a sexualidade, se não é "todo o romance", como afirma Alencar, ocupa enorme espaço dentro dele e, reflete, por trás da camada arquetípica, uma ambição mimética e documentadora da realidade externa ao texto.

\subsection{Cortando as asas das borboletas.}

a mulher pertence de direito ao homem que a ama e a quem adora mais que a própria vida

(Stendhal)

O caráter contestador e, em certa medida, progressista das obras urbanas de Alencar é como uma montanha-russa que alcança por um brevíssimo momento os altos píncaros e em seguida desce ao solo. Apesar das oscilações, excentricidades e ousadias apresentadas, o desfecho dos romances é previsível. Aurélia e Emília terminam a narrativa ajoelhando-se aos pés dos amados, suplicando perdão pelos desprezos e humilhações. O ar sarcástico e provocador desaparecem, e as moças, arrependidas, finalmente serão contempladas com "santo amor conjugal”. Em Lucíola, como vimos, o casamento não é uma possibilidade e a moral é ainda mais rigorosa. Apaixonando-se por Paulo, a heroína emerge em um processo de purificação do corpo que soa como uma tentativa desesperada de recuperar a virgindade perdida e, considerando-se incapaz de

179 PROENÇA, M. Cavalcanti. "José de Alencar na Literatura Brasileira", op. cit. P. 86 
viver uma relação amorosa como as outras mulheres, transforma-se gradativamente na "escrava submissa" que atende ao aceno de seu "amo e senhor".

Um grande defeito de Alencar, na opinião de Araripe Junior" ${ }^{180}$, é o de "facilitar muito as soluções nas últimas páginas dos seus livros”. Seja por impulso pessoal ou por medo de contrariar a opinião pública, o autor, à medida que as narrativas se aproximam do final, apressa-se em moralizar. Tal qual a "megera domada" de Shakespeare, as moças, depois de muito se rebelarem, tornam-se dóceis e ajustam-se finalmente às pretensões do par amoroso, e assim encarnam, de uma vez por todas, o ideal feminino preconizado, desde o início, pelo autor. Para Alencar, o amor faz com que a mulher se devote ao homem. Suas heroínas, por mais singulares que sejam, quando reconhecem-se apaixonadas, perdem completamente a individualidade e tornam-se uma parte, "uma coisa", um objeto à mercê do homem amado. "A minha vida terminou, começo agora a viver em $\mathrm{ti}^{181}$ ", escreve Emília quando finalmente decide confessar seu amor a Augusto. Aurélia também nomeia Seixas "senhor de sua ama”. Lúcia, como as demais, depois de muito hesitar, ao render-se ao amor de Paulo, renúncia a si mesma e, de joelhos, consagra-se ao amado:

\footnotetext{
Não sou eu criatura tua? Não renasci pela luz que derramaste em minha alma? Não és meu senhor, meu artista, meu pai e meu criador? $[\ldots]$

sou uma coisa tua, uma porção do teu ser; porque te pertenço e te sigo fatalmente; porque na terra como no céu, longe ou perto, vivo da tua vida. $^{182}$
}

É a partir daí que Lúcia adere definitivamente às ideias da moralidade burguesa, seu discurso se alinha com os discursos médico e religioso e seu arrependimento sincero, seguido da trajetória voluntária de martírio, sacrifício e expiação permite que ela sirva de exemplo para as "poucas mulheres que leem" no país.

Nesse sentido, devemos reconhecer que a representação do feminino nas obras de Alencar reflete o rígido padrão moralista do século, embora, ao mesmo tempo, traga,

180 ARARIPE JUNIOR. José de Alencar: perfil Literário. In: Obra Crítica de Araripe Junior, op. cit, p. 227.

181 ALENCAR, José de. Diva., op. cit, p. 66.

182 Lucíola, p. 325 e p. 326, respectivamente. 
em consonância com valores que o autor se esforça para legitimar, certa ânsia por progresso. Trata-se, como observou Luis Filipe Ribeiro, não exatamente de romper com os preconceitos da época, mas de "alargar-lhes as fronteiras e torná-las menos flexíveis $^{183,}$.

Esta é também a opinião de Gilberto Freyre e Roberto Schwarz, que apontamnos a adesão simultânea do romancista a dois termos antagônicos: tradicionalismo provinciano e modernismo. Por um lado, teríamos o Alencar conservador, "respeitador dos costumes", defensor dos direitos de sua classe e do patriarcalismo; por outro lado, o escritor contestador e apreciador das "modernidades", inclusive, segundo Freyre, no que se refere ao "desejo de certo certa emancipação da mulher" ${ }^{184}$. No embate entre os dois Alencares, sobressai-se, evidentemente, o conservador, mas a alternância de posturas não deixa de ilustrar as contradições inerentes à trajetória de um país em formação.

183 RIBEIRO, Luis Filipe. Mulheres de Papel, op. cit. p. 103.

184 C.f. FREYRE, Gilberto. "Reinterpretando José de Alencar.”. In: Vida, Forma e Cor. Rio de Janeiro: José Olímpio, 1962; e SCHWARZ, Roberto. "A Importação do Romance e suas Contradições em Alencar”. In: Ao Vencedor as Batatas. São Paulo: Duas Cidades/34, 2000. 


\section{Considerações Finais.}

O trabalho procurou demonstrar que a imagem da mulher apresentada por José de Alencar em Lucíola, se estrutura em uma dualidade bastante estanque que procura reproduzir e consolidar os ditames da moralidade burguesa. Esta dualidade, construída, em certa medida, por meio de um extenso arsenal arquetípico, fundamenta-se na dupla imagem feminina: "mulher-anjo" e "mulher-demônio", já calcificada no imaginário oitocentista por meio do discurso religioso, e reforçada e legitimada pela medicina higienista por meio de uma variante mais moderna: o duplo "mulher-nervosa" e "mulher-frígida". Interessado em imprimir à narrativa um caráter instrutivo, voltado para a edificação moral de um público leitor eminentemente feminino, Alencar ajuda a propagar a ideologia da domesticidade reforçando os dois modelos de feminilidade e, ao mesmo tempo, punindo os vícios e exaltando a virtude. Por outro lado, na ânsia por apresentar sua narrativa como um documento coerente com a realidade extratextual, o autor se aprofunda nas descrições do corpo feminino no embate com a sexualidade e termina por construir uma protagonista que, malgrado os extremos tanto para o sublime quanto para o grotesco, apresenta uma densidade humana surpreendente para os padrões literários da época.

Neste, como nos demais "perfis", Alencar propõe-se a desvendar a figura feminina e estudar o caráter da mulher excêntrica e enigmática à maneira dos "estudos de temperamento" que já no início do século estavam em evidência em terras europeias preludiando a ficção de cunho naturalista. No entanto, ao se aventurar por esses caminhos em solo brasileiro, o romancista tem de lidar com um assunto caro a um escritor já consagrado e envolvido no cenário político: as questões relacionadas à tensão sexual e seus desdobramentos. Os romances de G.M, sobretudo Lucíola e Diva, trazem o conflito sexual em primeiro plano, o que explica a reação negativa da crítica da época que considerou-as "monstrengos morais". Ao mover-se em campo perigoso, cujas agruras já havia experimentado com a peça: "As Asas de um Anjo", Alencar, em Lucíola, se utiliza de diversos meandros que visam compensar o assunto abordado, dentre os quais se destaca a criação da personagem interlocutora, leitora fictícia 
cúmplice do autor, que reforça a defesa de seu ponto de vista.

Ao final da pesquisa, foi possível concluir que as figuras femininas criadas por Alencar nos "perfis", ainda que sejam, por um lado, arquétipos construídos para determinar os papéis reservados à mulher na sociedade fluminense oitocentista, são também, personagens bastante complexas, mulheres "de carne e osso", como denominamos vulgarmente, que, em muitos aspectos mimetizam e, portanto, denunciam os mecanismos sociais que afetam o "ser mulher" nesta mesma sociedade. "Há em Alencar um sociólogo implícito" ${ }^{185}$, afirma Antonio Candido. Em Lucíola, na tentativa de traçar o perfil da cortesã às voltas com crises convulsivas que se revelam ao mesmo tempo crises de identidade relacionadas às questões sexuais e econômicas, Alencar demonstra, claramente, habilidades de sociólogo.

Talvez seja arriscado atribuir a qualquer das heroínas alencarianas uma "tonalidade feminista" como sugere Gilberto Freyre no estudo já referido e, mais recentemente, Maria Cecília Queirós de Moraes Pinto. O caráter edificante que Alencar imprime a suas obras, e o desejo incessante de regular o comportamento feminino de acordo com as diretrizes da moral burguesa com o qual nos deparamos durante todo o trabalho dificultariam ou mesmo inviabilizariam a sustentação de tal hipótese. Mas acreditamos, como Maria Cecília, que o trabalho de análise do texto literário deve estar atento também àquilo que a escrita expressa sem que o autor se dê conta completamente, ou seja, nos "rastros" deixados pelo texto que denunciam "o movimento involuntário do espírito $^{186, .}$ E, em Alencar, talvez sejam estes movimentos que proporcionem a criação de criaturas tão singulares e, ao mesmo tempo, tão contrárias, de certa forma, aos valores que insistia em canonizar.

185 CANDIDO, Antonio. “Os Três Alencares”. In: A Formação da Literatura Brasileira, op. cit. p. 540.

186 PINTO, Maria Cecília Queirós de Moraes Pinto. Alencar e a França: perfis, op. cit, p. 170. 


\section{Bibliografia:}

\section{De Alencar:}

ALENCAR, José de. Lucíola. In: José de Alencar: Obra Completa, vol. I. Rio de Janeiro: Aguilar, 1965.

_. Cinco Minutos. Obra Completa, vol.I. Rio de Janeiro: Aguilar, 1965.

. Viuvinha. In: Obra Completa, vol.I. Rio de Janeiro: Aguilar, 1965.

. Senhora. In: Obra Completa, vol. I. Rio de Janeiro: Aguilar, 1965.

. Encarnação. In: Obra Completa, vol. I. Rio de Janeiro: Aguilar, 1965

. Til. In: Obra Completa, vol III. Rio de Janeiro: Aguilar, 1958

. Diva. In: Obra Completa, vol. I. Rio de Janeiro: Aguilar, 1965.

. “O Jesuíta”. In: Teatro Completo, vol.II. Rio de Janeiro: Funarte, 1977.

• “A Expiação”. In: Teatro Completo, vol.II. Rio de Janeiro: Funarte, 1977.

$\frac{}{1977 .}$. "As Asas de um Anjo". In: Teatro Completo, vol II. Rio de Janeiro: Funarte, 1977.

. Ao Correr da Pena. São Paulo: Piratininga, s/d.

. Como e Porque Sou Romancista. Campinas:Pontes, 2005.

. Prólogo de O Guarani. São Paulo: Ática, 1990.

. Artigo sobre "As Asas de um Anjo" de 22 de junho de 1858. In: José de Alencar: Obra Completa, vol. IV. Rio de Janeiro: Aguilar, 1960. 
. "A Comédia Brasileira - Como e Porque sou Dramaturgo" In: José de

Alencar: Obra Completa, vol. IV. Rio de Janeiro: Aguilar, 1960.

. "Carta a D. Paula de Almeida". In: José de Alencar: Obra Completa, vol. I. Rio de Janeiro: Aguilar, 1859.

. "Os Sonhos d'Ouro". In: José de Alencar, obra Completa, v. IV. Rio de Janeiro: Aguilar, 1960.

Pós-escrito de "A Expiação". In: Teatro Completo, vol. II. Rio de Janeiro: Funarte, 1977. . Pós-escrito de Diva. Rio de Janeiro: Aguilar, 1965.

\section{De outros autores:}

ALMEIDA, Suely Creusa Cordeiro. O Sexo Devoto: normatização e resistência feminina no império português: XVI - XVIII. Recife: Ed. Universitária da UFPE, 2005.

ARARIPE JR, Tristão de Alencar. "José de Alencar: perfil literário". In: Obra Crítica de Araripe Jr. Rio de Janeiro: Ministério de Educação e Cultura. Casa de Rui Barbosa, 1958.

ARAÚJO, Emmanuel. "A Arte da Sedução: sexualidade feminina da Colônia". In: História das Mulheres no Brasil. Del Priore, Mary (org.). São Paulo: Editora Contexto, 2007.

BARBOSA, João Alexandre. "Leitura de José Alencar". In: Introdução a $O$ Guarani. São Paulo: Ed. Ática, [s.d]. . “Os Perfis de José de Alencar”. São Paulo: Revista Cult, set.99.

BEAUVOIR, Simone. O Segundo Sexo, vol. I e II São Paulo: Nova Fronteira, 1980.

BRANDÃO, Ruth Silviano. Mulher ao Pé da Letra - a Personagem Feminina na Literatura. Belo Horizonte: Ed. UFMG, 2006. 
CANDIDO, Antonio. A Formação da Literatura Brasileira. Rio de Janeiro: Ouro sobre Azul, 2007.

. “A Timidez no Romance”. In: Educação pela Noite \& Outros Ensaios. São Paulo: Ed. Ática, 1987.

COSTA, Emília Viotti da. Da Monarquia à República. São Paulo: Editora Unesp, 1998.

COSTA, Jurandir Freire. Ordem Médica e Norma Familiar. São Paulo: Graal, 2004.

COUTINHO, Afrânio (org). A Polêmica Alencar/Nabuco. Rio de Janeiro: Ed. Tempo Brasileiro, 1965.

DE MARCO, Valéria. O Império da Cortesã; Lucíola: um perfil de Alencar. São Paulo: Martins Fontes, 1986.

DEL PRIORE, Mary. "Magia e Medicina na Colônia". In: História das Mulheres no Brasil. Del Priore, Mary (org.) São Paulo: Editora Contexto, 2007.

. Ao Sul do Corpo: condição feminina, maternidades e mentalidades no Brasil Colônia. Rio de Janeiro: José Olímpio; Brasília, D.F: Edunb, 1993.

D'INCAO, Maria Angela. "Mulher e Família Burguesa”. In: In: História das Mulheres no Brasil. Del Priore, Mary (org.). São Paulo: Editora Contexto, 2007.

ELIADE, Mircea. O Sagrado e o Profano - a essência das religiões. São Paulo: Martins Fontes, 2008.

ENGEL, Magali. "Psiquiatria e Feminilidade". In: História das Mulheres no Brasil. Del Priore, Mary (org.). São Paulo: Editora Contexto, 2007.

. Meretrizes e Doutores: Saber Médico e Prostituição no Rio de Janeiro (1840 1890). São Paulo: Brasiliense, 2004.

EXPILLY, Charles. Mulheres e Costumes no Brasil. Rio de Janeiro: Itatiaia, 2000.

FARIA, João Roberto. José de Alencar e o Teatro. São Paulo: Perspectiva, 1987. 
FOUCAULT, Michel. A História da Sexualidade, vol. I. São Paulo: Graal, 2007.

FREYRE, Gilberto. Sobrados e Mucambos. São Paulo: Global Editora, 2003.

. "Reinterpretando José de Alencar". In: Vida, Forma e Cor. Rio de Janeiro: José Olímpio, 1962.

FRYE, Northrop. "Crítica Arquetípica: Teoria dos Mitos”. In: Anatomia da Crítica. São Paulo: Cultrix, 1957.

GAY, Peter. O Coração Desvelado. São Paulo: Cia das Letras, 1999.

GUIMARÃES, Hélio de S. Os Leitores de Machado de Assis. São Paulo: Edusp, 2005.

GUINSBURG, Jacó. (org.). O Romantismo. São Paulo: Perspectiva, 1993.

HAHNER, June E. A Mulher no Brasil. Rio de Janeiro: Editora Civilização Brasileira, 1978.

HALLEWEL, Laurence. O Livro no Brasil: sua história. São Paulo: T.A. Queirós: Edusp, 1985.

HUGO, Victor. Do Grotesco e do Sublime. São Paulo: Perspectiva, 1988.

LAFETÁ, João Luiz. “As Imagens do Desejo”. In: Senhora. São Paulo: Ática, 1990.

LEITE, Dante Moreira. Psicologia e Literatura. São Paulo: Unesp/ Ucitec, 1987. . O Amor Romântico e Outros Temas. São Paulo: Companhia Editora Nacional, 1979.

LÖWY, Michael, SAYRE, Robert. Revolta e Melancolia, o Romantismo na contramão da modernidade. Petrópolis, R.J: Vozes, 1995.

LUCCOCK, John. Notas sobre o Rio de Janeiro e partes meridionais do Brasil. Tomadas durante uma estada de dez anos nesse país, de 1808 a 1818. São Paulo: Martins, 1942. 
MAGALHÃES JR, Raymundo. José de Alencar e sua Época. Rio de Janeiro: Livros Irradiantes, [s.d].

MARTINS, Eduardo Vieira. A Fonte Subterrânea - José de Alencar e a Retórica Oitocentista. São Paulo: Edusp, 2005.

MEYER, Augusto. "Alencar e a Tenuidade Brasileira". In: José de Alencar, obra completa, vol. II. Rio de Janeiro: Aguilar, 1964.

MONTENEGRO, Olívio. "José de Alencar". In: O Romance Brasileiro. Rio de Janeiro: José Olympio, 1953.

MOTA, Artur. José de Alencar (o escritor e o político) - sua vida e sua obra. Rio de Janeiro, F. Briguet, 1921.

MURICY, Kátia. A Razão Cética, Machado de Assis e as Questões de seu tempo. São Paulo: Cia das Letras, 1988.

NUNES, Silvia Alexim. O Corpo do Diabo entre a Cruz e a Caldeirinha - um estudo sobre a mulher, o masoquismo e a feminilidade. Rio de Janeiro: Civilização Brasileira, 2000 .

PERROT, Michelle. Minha História das Mulheres. São Paulo: Editora Contexto, 2007.

PINTO, Maria Cecília Queiroz de M. Alencar e a França, perfis. São Paulo: Annablume, 1999.

PLATÃO. Timeu. São Paulo: Instituto Piaget, 2004.

PONTIERI, Regina Lúcia. A Voragem do Olhar. São Paulo: Perspectiva, 1988.

PRAZ, Mario. A Carne, a Morte e o Diabo na Literatura Romântica. Campinas, SP: Editora da Unicamp, 1996.

PROENÇA, M. Cavalcanti. José de Alencar na Literatura Brasileira. Rio de Janeiro: Ed. Civilização Brasileira, 1966.

RIBEIRO, Luis Filipe. Mulheres de Papel: um estudo do imaginário em José de Alencar e Machado de Assis. Niterói, R.J: Eduff, 1996. 
ROSENFELD, A./ GUINSBURG, J. "Romantismo e Classicismo”. In: O Romantismo. J. Guinsburg (org). São Paulo: Perspectiva, 1993.

SANT'ANNA, Affonso Romano de. O Canibalismo Amoroso. São Paulo: Círculo do Livro, [s/d].

SANTIAGO, Silviano. Romance para Estudo: Iracema. Rio de Janeiro: Francisco Alves, 1975.

SCHLEGEL, Friedrich. "Discurso sobre a mitologia". In: Conversa sobre Poesia e outros Fragmentos. São Paulo: Iluminuras, 1994.

SCHWARZ, Roberto. “A Importação do Romance e suas Contradições em Alencar". In: Ao Vencedor as Batatas. São Paulo: Duas Cidades/34, 2000.

SEGOLIN, Fernando. Personagem e Anti-personagem. São Paulo: Olho d'Água, 2006.

SOARES, Luis Carlos. Rameiras, Ilhoas, Polacas: a prostituição no Rio de Janeiro do Século XIX. São Paulo: Ática, 1992.

SWAIN, Gladys. "A Alma, a Mulher e o Corpo - as metamorfoses da histeria no fim do século XIX". In: O Feminino: aproximações. Joel Birman e Carlos Augusto Nicéas (org). Rio de Janeiro: Editora Campus Ltda, 1986.

TAUNAY, Visconde de. Reminiscências . São Paulo: Comp. Melhoramentos, 1923. . Inocência. Rio de Janeiro: Tecnoprint, 1969.

TÁVORA, Franklin. Cartas a Cincinnato; estudos críticos de Semprônio. Pernambuco. J.W. De Medeiros, 1872.

VERÍSSIMO, José. “José de Alencar". In: José de Alencar, Obra Completa, vol III. Rio de Janeiro: Aguilar, 1958.

VIANA FILHO, Luís. A Vida de José de Alencar. Rio de Janeiro: José Olímpio, 1979.

WERNECK, Maria Helena Vicente. Mestra: entre agulhas e amores: a leitora do século XIX na literatura de Machado e Alencar. Rio de Janeiro: Pontifícia Universidade Católica, 1985. Dissertação de mestrado. 


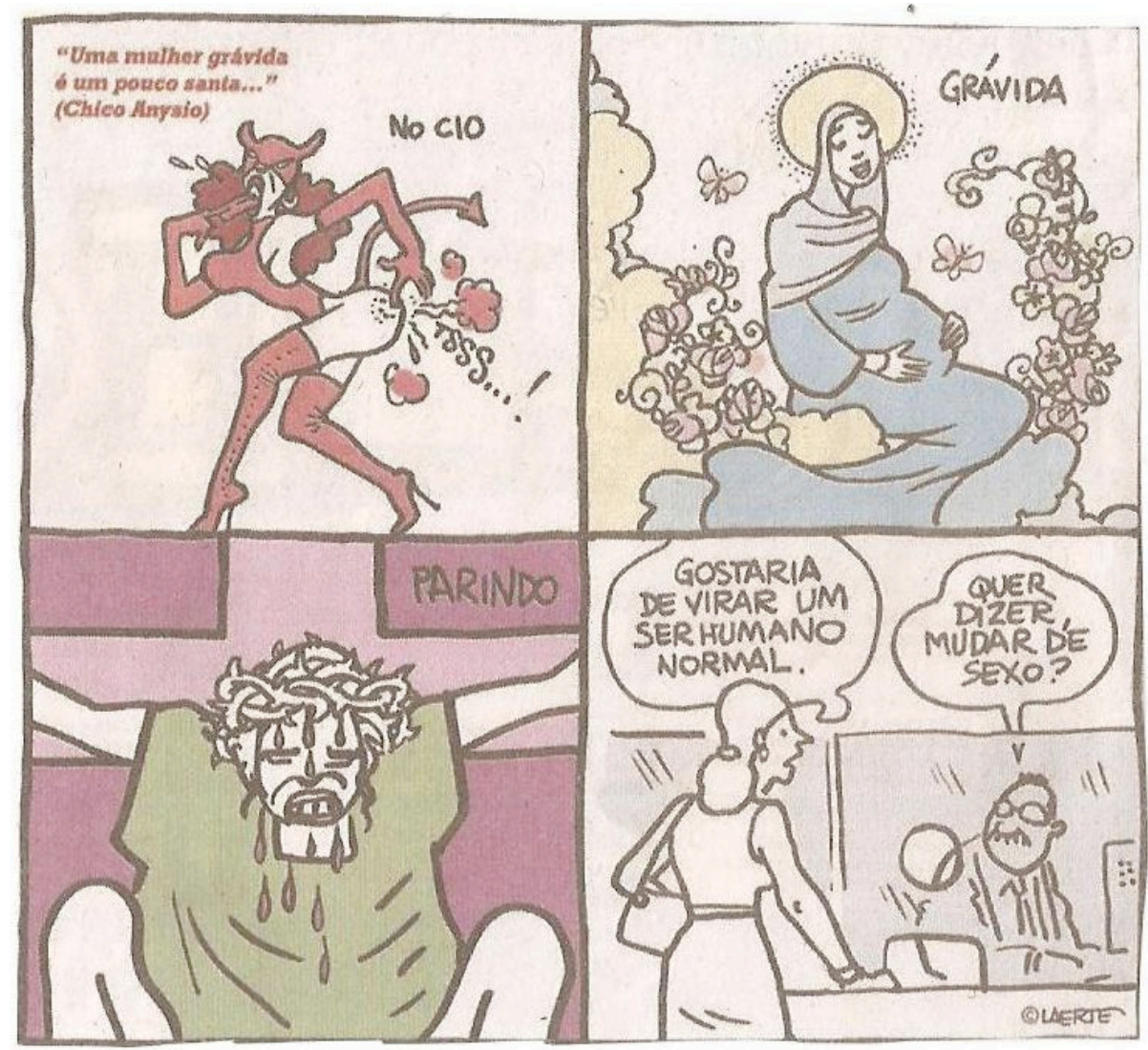

LAERTE. Folha de São Paulo, Ilustrada, 8 de outubro de 2011. 